\title{
Additional Archaeological Investigations of the Propised Fulton Mansion Visitor's Center, Fulton Mansion State Historic (41AS79), Rockport, Aransas County, Texas
}

Carole Leezer

Center for Archaeological Studies

Julian A. Sitters

Texas Historical Commission

Cinda Timperley

Center for Archaeological Studies

Follow this and additional works at: https://scholarworks.sfasu.edu/ita

Part of the American Material Culture Commons, Archaeological Anthropology Commons, Environmental Studies Commons, Other American Studies Commons, Other Arts and Humanities Commons, Other History of Art, Architecture, and Archaeology Commons, and the United States History Commons

Tell us how this article helped you.

This Article is brought to you for free and open access by the Center for Regional Heritage Research at SFA ScholarWorks. It has been accepted for inclusion in Index of Texas Archaeology: Open Access Gray Literature from the Lone Star State by an authorized editor of SFA ScholarWorks. For more information, please contact cdsscholarworks@sfasu.edu. 
Additional Archaeological Investigations of the Propised Fulton Mansion Visitor's Center, Fulton Mansion State Historic (41AS79), Rockport, Aransas County, Texas

Creative Commons License

(c) (1) (8)

This work is licensed under a Creative Commons Attribution-NonCommercial 4.0 International License 
Additional Archaeological Investigations of the Proposed Fulton Mansion Visitor's Center, Fulton Mansion State Historic Site (41AS79), Rockport, Aransas County, Texas
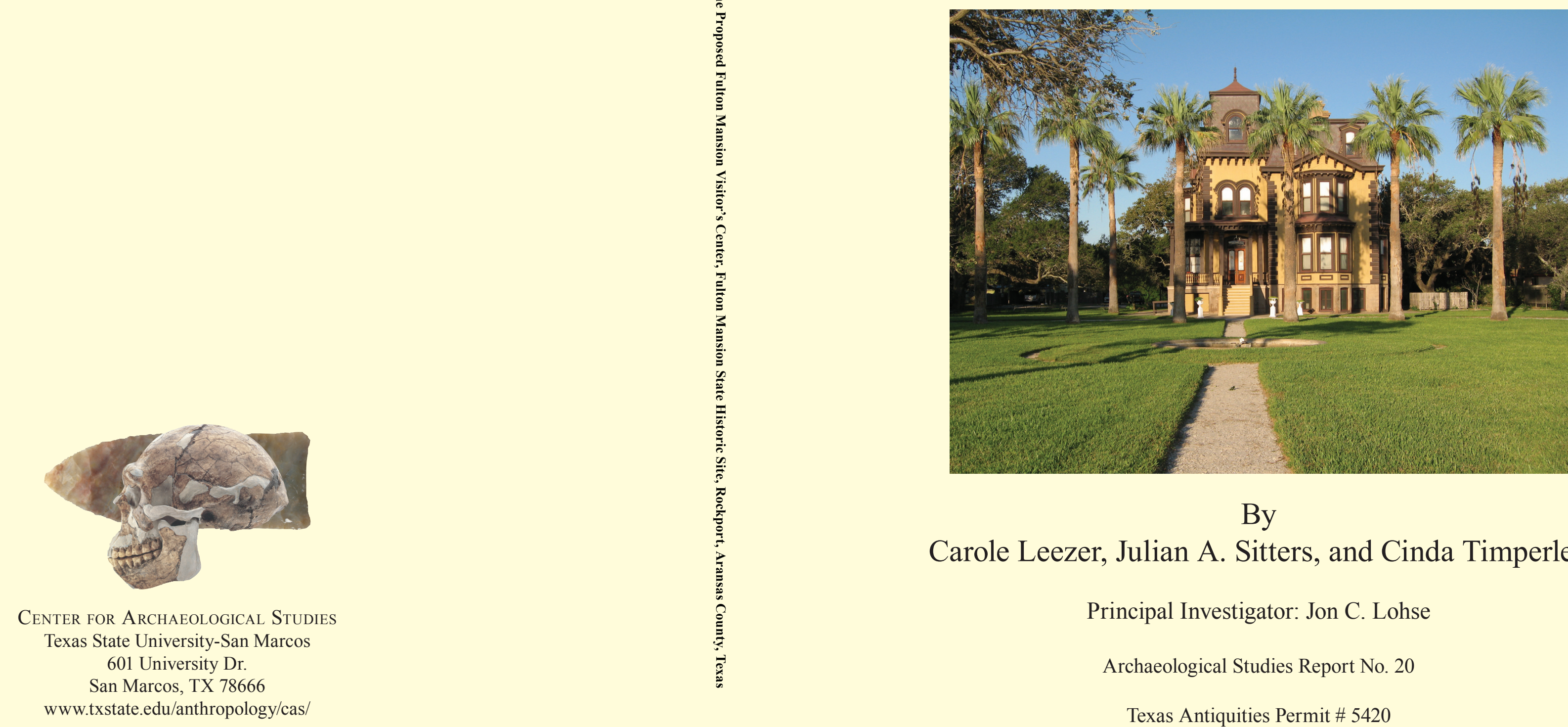

By

Carole Leezer, Julian A. Sitters, and Cinda Timperley

Principal Investigator: Jon C. Lohse Archaeological Studies Report No. 20 Texas Antiquities Permit \# 5420 CSJ: 0916-38-005

$\frac{\text { TEXAS STATE }}{\text { UNIVERSITY }}$ SAN MARCOS
The rising STAR of Texas 


\title{
Additional Archaeological Investigations of the Proposed Fulton Mansion Visitor's Center, Fulton Mansion State Historic Site (41AS79), Rockport, Aransas County, Texas
}

\author{
by \\ Carole Leezer, Julian A. Sitters, and Cinda Timperley \\ Principal Investigator: Jon C. Lohse \\ Texas Antiquities Permit \# 5420 \\ Texas Department of Transportation Statewide Transportation \\ Enhancement Program
}

CSJ: 0916-38-005

Prepared for:

Texas Historical Commission

Historic Sites Division

And

Texas Department of Transportation

Corpus Christi District Environmental Section

Archaeological Studies Report No. 20

Center for Archaeological Studies

Texas State University-San Marcos 
The following information is provided in accordance with the General Rules of Practice and Procedures, Title 13, Chapter 26, Texas Administrative Code:

1. Type of investigation: An archaeological testing project consisting of backhoe trench and test unit excavation for the Fulton Mansion Visitor's Center enlarged parking area, internet cable line trench monitoring, and shovel test unit investigation of irrigation system.

2. Project name: Additional Archaeological Investigations of the Proposed Fulton Mansion Visitor's Center, Fulton Mansion State Historic Site, Rockport, Aransas County, Texas

3. County: Aransas

4. Principal Investigator: Jon C. Lohse

5. Name and location of sponsoring agency: Texas Historical Commission, Austin, Texas

6. Published by the Center for Archaeological Studies, Texas State University-San Marcos, 601 University

Drive, San Marcos, Texas, 78666-4616 (2010)

Texas State University-San Marcos is a member of the Texas State University System Copyright (C) 2010 by the Center for Archaeological Studies at Texas State University-San Marcos

All rights reserved.

No part of this book may be reproduced or utilized in any form or by any means, electronic or mechanical, including photocopying, recording,

or by any information storage and retrieval system without permission in writing.

For further information on this and other publications by

the Center for Archaeological Studies, please contact:

Center for Archaeological Studies

Texas State University-San Marcos

601 University Drive

San Marcos, TX 78666-4616

www.txstate.edu/anthropology/cas/

Editor: Brooke Boyer

Cover Photograph: Fulton Mansion.

Printed in the United States of America

by

Ginny's Printing Inc., Austin 


\section{Management Summary}

PROJECT TITLE: Additional Archaeological Investigations of the Proposed Fulton Mansion Visitor's Center, Fulton Mansion State Historic Site

TXDOT CSJ NUMBER: TXDOT Statewide Transportation Enhancement Program CSJ 0916-38-005

PROJECT DESCRIPTION: an archaeological testing project consisting of backhoe trench and test unit excavation for the Fulton Mansion Visitor's Center enlarged parking area, internet cable line trench monitoring, and shovel test unit investigation of irrigation system.

SPONSOR: Texas Historical Commission Historic Sites Division

LOCATION: Fulton Mansion State Historic Site, Rockport, Aransas County, Texas

PRINCIPAL INVESTIGATOR: Jon C. Lohse

PROJECT ARCHAEOLOGIST: Carole Leezer

CREW MEMBERS: Julian A. Sitters and Sarah Scogin

INSTITUTION: Center for Archaeological Studies, Texas State University-San Marcos

TEXAS ANTIQUITIES PERMIT: 5420

DATES OF WORK: October 19, 2009 to November 13, 2009

MAN HOURS: 162

TOTAL ACERAGE EVALUATED: approximately 1.6 acres

PURPOSE OF WORK: Because the project is partially financed by a Statewide Transportation Enhancement Program, it is subject to the provisions of Section 106 of the National Historic Preservation Act of 1966 (NHPA). The current project was developed to determine the presence of archaeological resources within the APE and evaluate any resources for eligibility for listing to the National Register of Historic Places. The project also is subject to the provisions of the Texas Antiquities Code. Investigations will evaluate any resources for eligibility and designation as a State Archeological Landmark to determine whether the proposed undertaking will affect archaeological historic properties. The proposed project was originally nominated and sponsored by the Texas Parks and Wildlife Department but was subsequently transferred to the Texas Historical Commission with oversight by TxDOT. 


\section{Management Summary (CONTinued)}

\section{NUMBER OF SITES: 1}

CURATION: Texas Historical Commission Historic Sites Division

COMMENTS: Three cultural faunal deposits similar to those encountered in previous investigations were identified in the proposed parking lot area. CAS recommends that the deposits constitute a contributing element to the NRHP listing and SAL status of the Fulton Mansion. As a result of the fill placement, no National Register eligible historic resources will be affected by the proposed development. CAS recommends that a layer of fill sufficient to avoid impact to these deposit be utilized in the parking lot construction. Irrigation system installation should avoid the southwest corner of the mansion property as there is a high potential for a prehistoric deposit in this area. CAS recommends that a "no historic properties affected" determination is appropriate and that the project and the enhancement funding should move forward. 


\section{Abstract}

The Center for Archaeological Studies at Texas State University-San Marcos conducted additional archaeological investigations for the proposed Fulton Mansion State Historic Site (41AS79) Visitor's Center, Aransas County, Texas, between October 19 and November 13, 2009 on behalf of the Texas Historical Commission Historic Sites Division. Investigations of the Area of Potential Effect are a continuation of testing investigations begun by Ringstaff in 2007 (Ringstaff 2008). Work was carried out by Carole Leezer as Project Archaeologist, Julian A. Sitters and Sarah Scogin as Archaeological Technicians, and Jon C. Lohse as Principal Investigator under Texas Antiquities Permit No. 5420. Investigations included backhoe trench excavation, test unit excavation, shovel test unit excavation, and monitoring of internet cable installation. Three deposits of faunal remains were encountered during backhoe trench excavations and fully excavated during test unit excavations. Remains consisted primarily of green sea turtle (Cheloniidae). Additional shovel test units were excavated in the area where a proposed irrigation system will be installed. A total of 20 shovel test units were excavated across the front and side lawns of the mansion property to determine whether the modern fill layer identified by Ringstaff (2008) in the footprint of the proposed Visitor's Center was also present in this location. A fill layer was noted in locations of a previous driveway. No intact cultural deposits or features were encountered during shovel test excavations with the exception of three culturally modified clam shell pieces. Their recovery from the bottom of a shovel test unit at $31 \mathrm{~cm}$ below surface suggests a high probability for prehistoric cultural remains in this area below this depth. Archaeological monitoring of an internet cable installation was also conducted. No intact significant cultural features were encountered. All collected cultural materials were prepared for curation; temporarily, at the Center for Archaeological Studies, Texas State University-San Marcos, and permanently curated at the Texas Historical Commission. 


\section{Table of Contents}

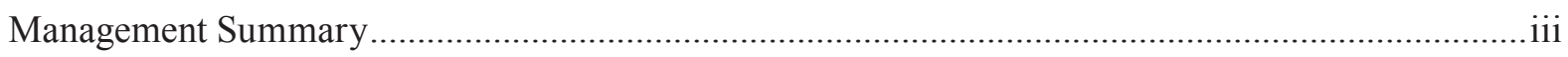

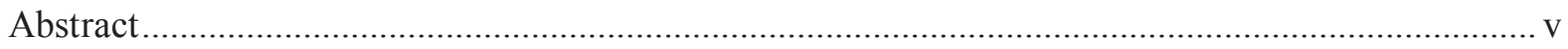

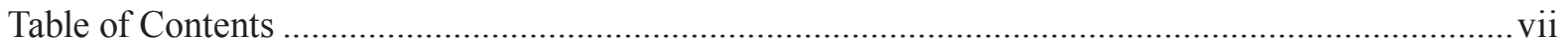

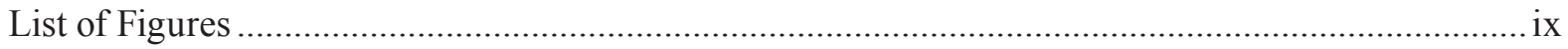

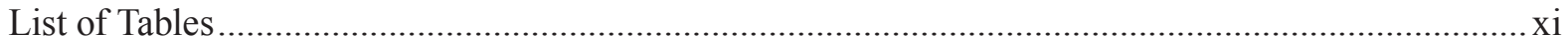

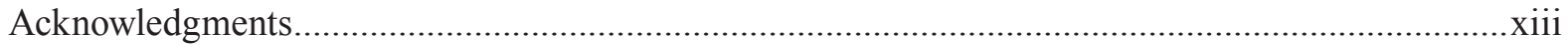

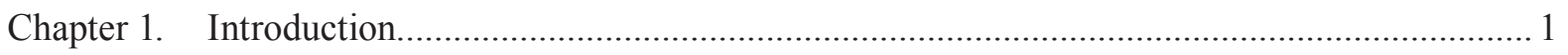

Chapter 2. Project Setting and Cultural Chronology ….................................................................. 7

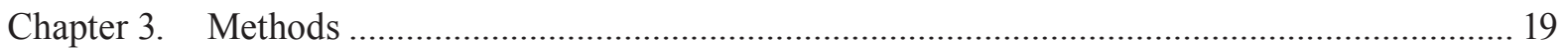

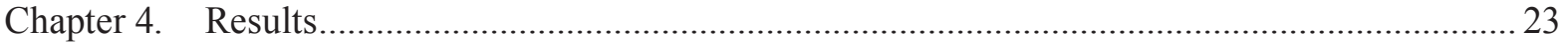

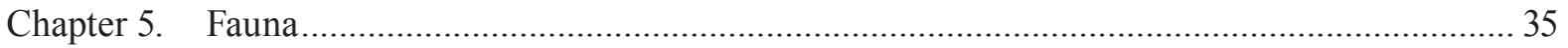

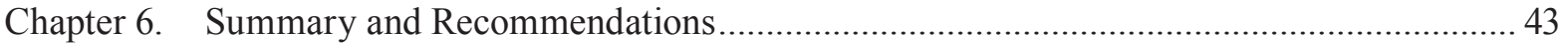

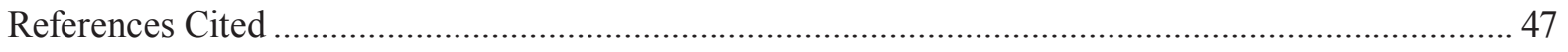

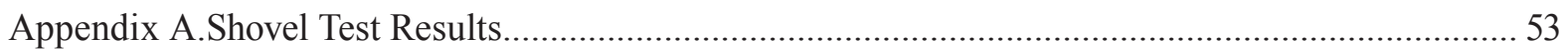

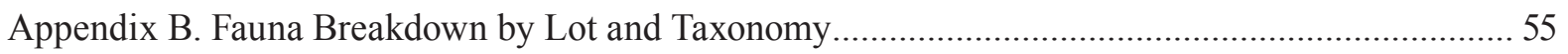

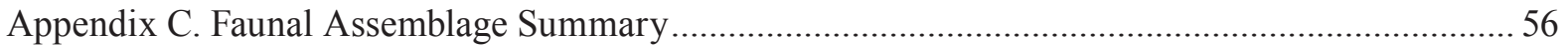

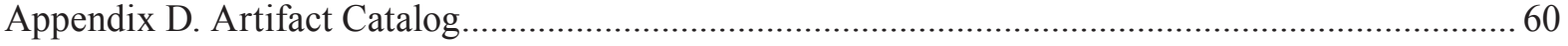




\section{List OF Figures}

1-1. Project Location Map (Fulton Mansion State Historic Site property boundary in yellow).......... 1

1-2. Previous and current backhoe trench locations. …............................................................ 2

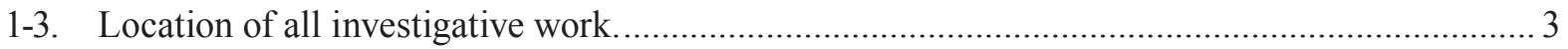

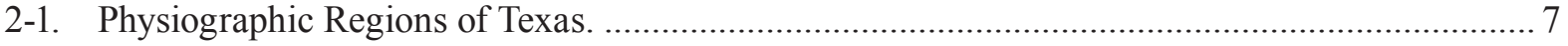

2-2. Fulton Mansion Historical Marker.......................................................................................... 9

2-3. George W. Fulton Historical Marker...................................................................................... 9

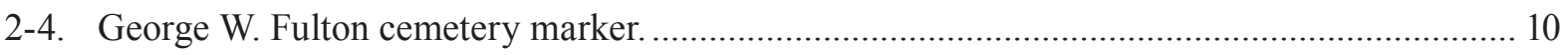

4-1. Location of Ringstaff's excavations (from Ringstaff 2008; Figure 4) .................................... 23

4-2. Backhoe trenches and internet cable trench location map.................................................... 24

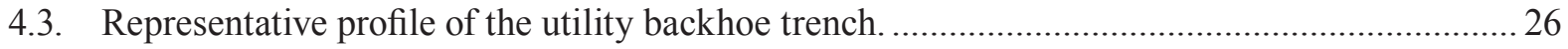

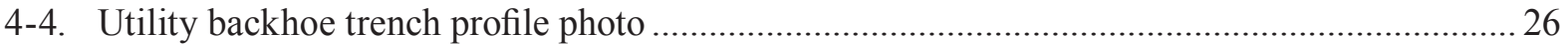

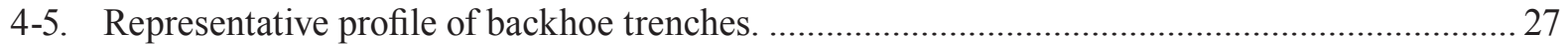

4-6. Photo of deposit in profile of Eastern Backhoe Trench; facing northeast. Discolored spots are

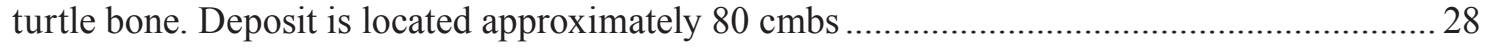

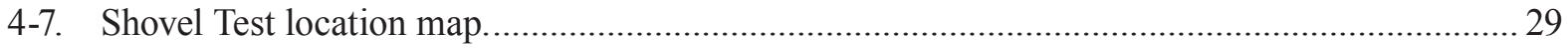

4-8. Three modified shell fragments; back of shells on left, front on right. ................................... 30

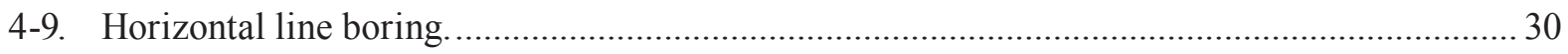

4-10. Profile picture of Bore Hole A southern wall ....................................................................... 31

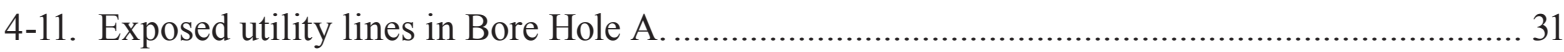

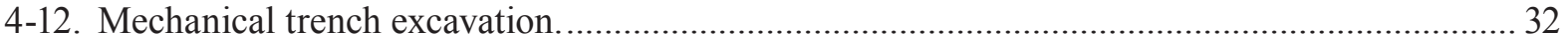

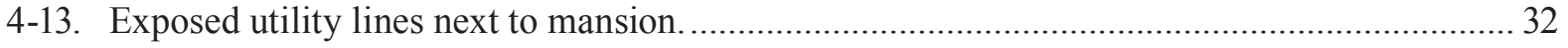

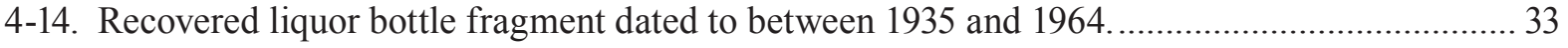

5-1. Right pectoral element of Chelonia mydas (green sea turtle) in lateral view.......................... 38

5-2. Left humerus of Chelonia mydas (green sea turtle) in A: ventral, B: dorsal view .................... 38

5-3. Pleural fragments of Chelonia mydas (green sea turtle) exhibiting lumpy remodeled exterior bone indicative of healed infection 


\section{List OF Figures (Continued)}

5-4. Cheloniidae bone fragment with scalloped edges typical of carnivore activity...................... 39 


\section{List OF TABLES}

4-1. Shovel Test Units with Recovered Artifacts ..................................................................... 28

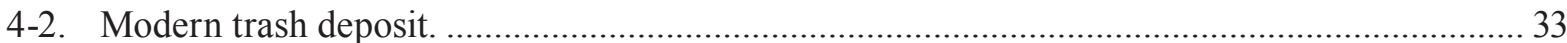




\section{ACKnOWledgments}

The Center for Archaeological Studies greatly appreciates the support for this project that was provided by Brett Cruse, Marsha Hendrix, Robert Field, and Rick Howard of the Texas Historical Commission. Field work was carried out by Carole Leezer, who served as Project Archaeologist, and by CAS Archaeological Technicians, Julian A. Sitters and Sarah Scogin. Faunal analysis was completed by Cinda Timperley. Brooke Boyer was tremendously helpful with the editing and layout of the final version of this report. 


\section{Chapter 1}

\section{INTRODUCTION}

Carole Leezer

The Center for Archaeological Studies (CAS) at Texas State University-San Marcos conducted additional archaeological investigations for the proposed Fulton Mansion State Historic Site Visitor's Center, Aransas County, Texas, between October 19 and November 13, 2009. The Texas Historical Commission (THC) intends to enhance the Fulton Mansion State Historic Site by constructing a visitor's center and parking area to be located west of the Fulton Mansion (Figure 1-1), partially funded by a Texas Department of Transportation (TxDOT) Statewide Enhancement Program. A testing project for the Fulton Mansion Visitor's Center was conducted by the Texas Parks and Wildlife Department (TPWD) in 2007 while the site was under TPWD management (Ringstaff 2008). Since then, the site has come under the management of the Texas Historical Commission and the area of potential effect (APE) of the visitor's center has doubled to accommodate an enlarged parking area. The footprint of the visitor's center will be approximately $5,696 \mathrm{ft}^{2}$, including 4,136 $\mathrm{ft}^{2}$ of enclosed space and 1,560 $\mathrm{ft}^{2}$ of decking and steps. This area was subject to test excavations conducted in 2007 (Ringstaff 2008). Additionally, a $10,238 \mathrm{ft}^{2}$ paved parking lot will be constructed immediately to the south of the visitor's center. The parking lot area was the focus of the current investigation project (Figure 1-2). Utilities

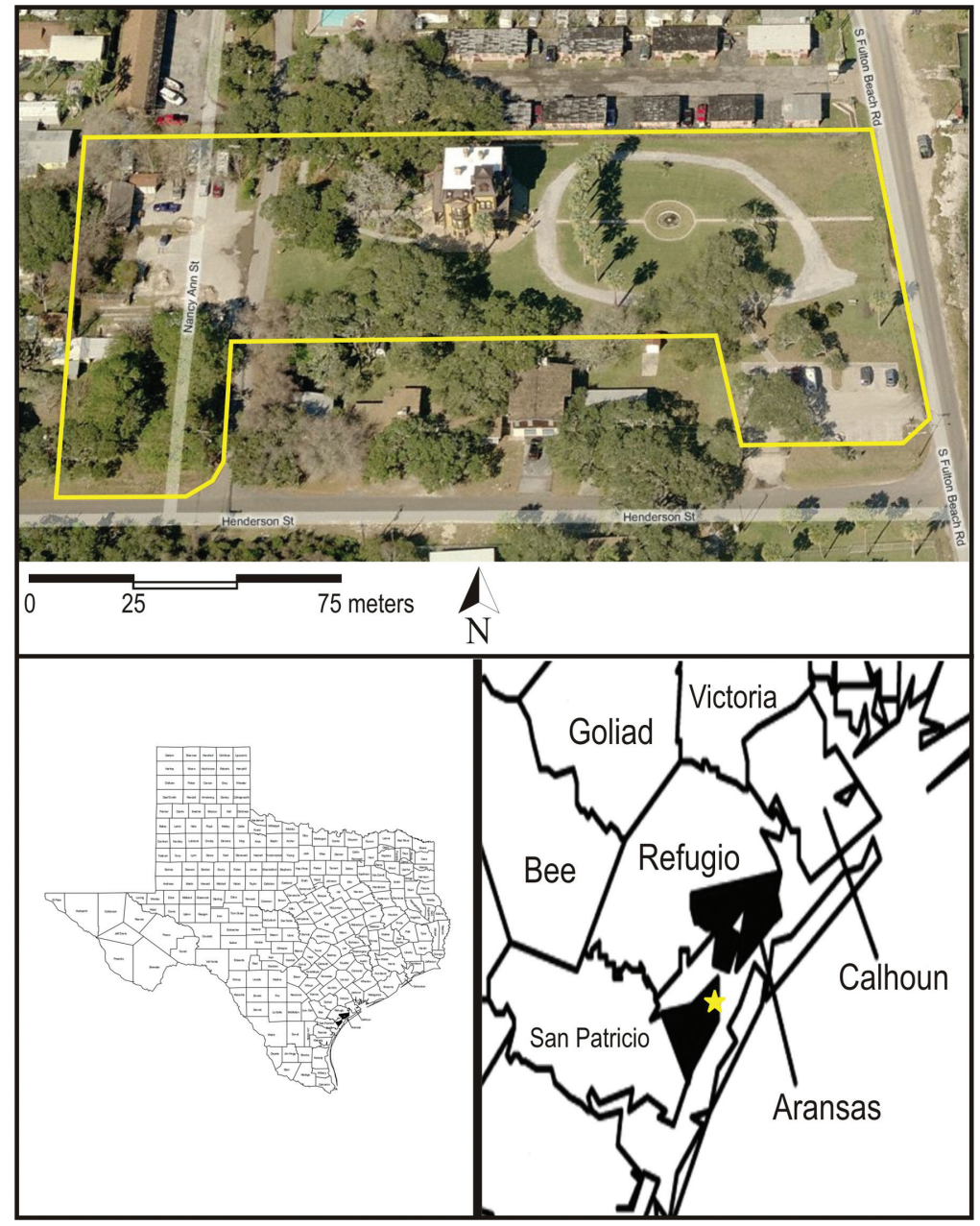

Figure 1-1. Project Location Map (Fulton Mansion State Historic Site property boundary in yellow). 
include sewer, water, electric, telephone, and cable. The current archaeological testing project will examine the new, previously untested area of the expanded parking lot and electric utility line, while also addressing some recommendations from the earlier project. Investigations during this phase of the project consisted of the excavation of backhoe trench units to determine whether additional cultural deposits were located within the area of the propose parking lot and electric line, and if they were similar to those previously encountered deposits (Figure 1-3). The APE for this portion of the investigation consists of the proposed expanded parking lot of approximately
$951 \mathrm{~m}^{2}$ with an anticipated impact to be no more than $30 \mathrm{~cm}$ in depth. The APE of the electrical utility line is approximately $10 \mathrm{~m}$ in length, 50 $\mathrm{cm}$ in width and $80 \mathrm{~cm}$ in depth.

Shovel test units were also excavated in advance of a proposed irrigation system to be installed on the front and side lawns of the Fulton Mansion grounds (Figure 1-3). Shovel test units were excavated to determine whether a modern fill layer documented during the 2007 investigations was present within the APE or whether the fill layer was absent and intact archaeological materials are present. The APE

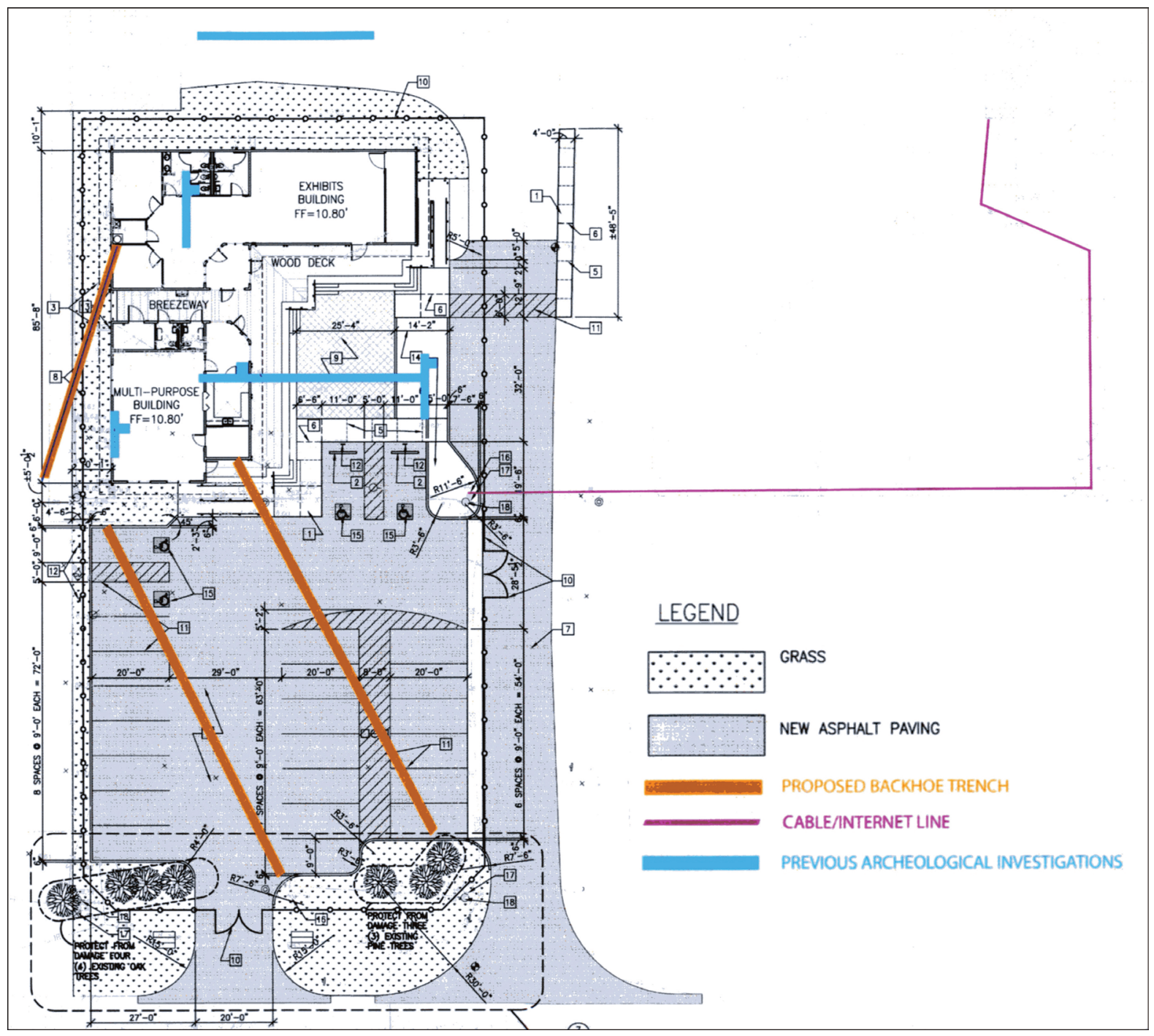

Figure 1-2. Previous and current backhoe trench locations. 
for this portion of the project is approximately $5500 \mathrm{~m}^{2}$ with an anticipated depth of impact no deeper than $30 \mathrm{~cm}$.

CAS also conducted archaeological monitoring of the installation of an underground cable internet line extending from the southwest corner of the Fulton Mansion south to the property boundary, and then west to the proposed visitor's center (Figure 1-3). The APE for this portion of the project is an approximate $72 \mathrm{~m}$ long with a width of $50 \mathrm{~cm}$ and depth of $50 \mathrm{~cm}$. All cultural features encountered during investigations were recorded and/or fully exposed, and excavated by controlled hand excavations.

The National Register nomination form for the Fulton Mansion describes the acreage of the nominated property to consist of one acre. It is therefore assumed that the National Register property consists of the Fulton Mansion structure and one acre of land upon which it sits. The Fulton

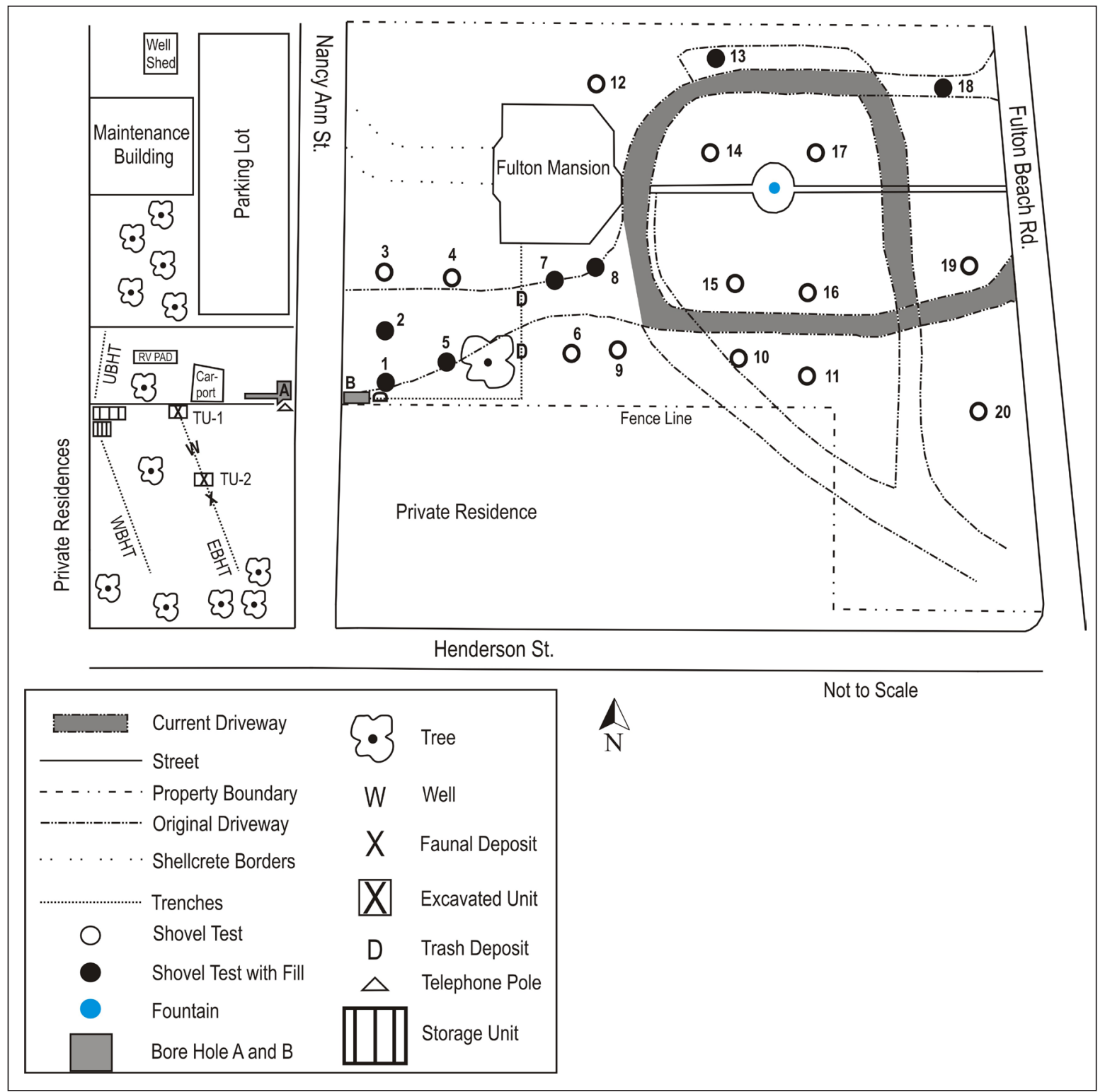

Figure 1-3. Location of all investigative work. 
Mansion State Historic Site was designated a State Archeological Landmark on February 22, 1983, a time when property boundaries were not recorded. For the purpose of the current project, the property boundaries of the Fulton Mansion are assumed to be those lands upon which the mansion sits that are owned and controlled by the Texas Historical Commission. This area consists of 2.72 acres and is outlined in yellow in Figure $1-1$.

Work was carried out by The Center for Archaeological Studies at Texas State UniversitySan Marcos with Carole Leezer as Project Archaeologist and Archaeological Technicians Julian A. Sitters and Sarah Scogin, under Texas Antiquities Permit Number 5420. Jon C. Lohse served as Principal Investigator. Investigations were conducted between October 19, 2009 and November 13, 2009.

\section{Report Organization}

This report is organized in six chapters. Chapter 1 includes an introduction and the regulatory criteria for the investigations conducted. Chapter 2 provides a description of the project area and includes a summary of the project area's geology and soils, vegetation, and a summary of previous investigations. Background information on the cultural history of the project area including both prehistoric and historic histories, as well as a summary of the historical and architectural significance of the Fulton Mansion are also presented within this chapter. Chapter 3 describes the investigative methods employed. All investigations were conducted in compliance with the Texas Historical Commission (THC) and the Council of Texas Archeologist (CTA) guidelines as referenced in 12 TAC 26.20 and THC policy. Chapter 4 documents the results of backhoe trench and test unit excavation, shovel test unit excavation and archaeological monitoring of internet cable installation. This section includes a summary of the analysis of collected cultural materials. An in-depth analysis of collected faunal material is presented in Chapter 5. Finally, Chapter 6 summarizes the archaeological investigations and presents recommendations. This section provides an assessment of National Register of Historic Places (NRHP) and State Archeological Landmark eligibility and possible contributing elements and if the proposed construction will adversely affect eligibility. Recommendations for further work, if any are also presented in this chapter.

\section{Regulatory Criteria}

As the construction project is partially funded by a Statewide Transportation Enhancement Program administered by TxDOT, it is subject to the provisions of Section 106 of the National Historic Preservation Act of 1966 (NHPA). The current project was developed to determine the presence of archaeological resources within the APE and evaluate any resources for eligibility for listing to the National Register of Historic Places (NRHP) (36 CFR 60.4). Recommendations for eligibility will be presented to the Texas Department of Transportation (TxDOT) and the State Historic Preservation Officer (SHPO). All work will be conducted under terms of first amended Programmatic Agreement among FHWA, TxDOT, the Advisory Council on Historic Preservation, the Texas SHPO (2005), and the Memorandum of Understanding between TxDOT and THC.

The project is also subject to the provisions of the Texas Antiquities Code, now subsumed 
in Title 13, Part II of the Texas Administrative Code as the property is managed by the Texas Historical Commission. This legislation defines the necessary conditions for the recognition and preservation of State Archeological Landmarks (SALs) and requires that any political subdivision of the State of Texas, defined as a local government entity created and operating under the laws of this state, including a city, county, school district, or special district created under the Texas Constitution, Article III, 52 (b)(1) or (2), or Article XVI, 59 in 13 TAC 26.5 of the code, must identify potential SALs through survey of public lands prior to actions that could potentially damage those SALs. The code's provisions are administered by the Texas Historical Commission (THC) Archeology Division. The Fulton Mansion is currently listed as a Texas State Archeological Landmark (SAL) (13 TAC 26.8). The current investigation evaluates resources for their potential to be contributing elements to the SAL and whether the proposed undertaking will affect archaeological historic properties (36 CFR $800.16(1))$ or SAL status (13 TAC 26.12). 


\section{Chapter 2}

\section{Project Setting and \\ Cultural Chronology}

Carole Leezer

\section{Project Area Description}

The Fulton Mansion is located in Rockport, Aransas County, Texas on the eastern shore of the Live Oak Peninsula (see Figure 1-1). Aransas County is located on the Texas Gulf Coast northeast of Corpus Christi. The county is divided into three sections by Copano Bay, St. Charles Bay, and Aransas Bay. It is bounded on the north and northwest side by Refugio County, on the south by San Patricio and Nueces counties, and on the east by the Gulf of Mexico. The largest city in Aransas County and the county seat is Rockport. Several highways cross the county, including State highways 35 and 361, and Farm to Market roads 136, 881, 1781, 2040, 2165, 2725 ,

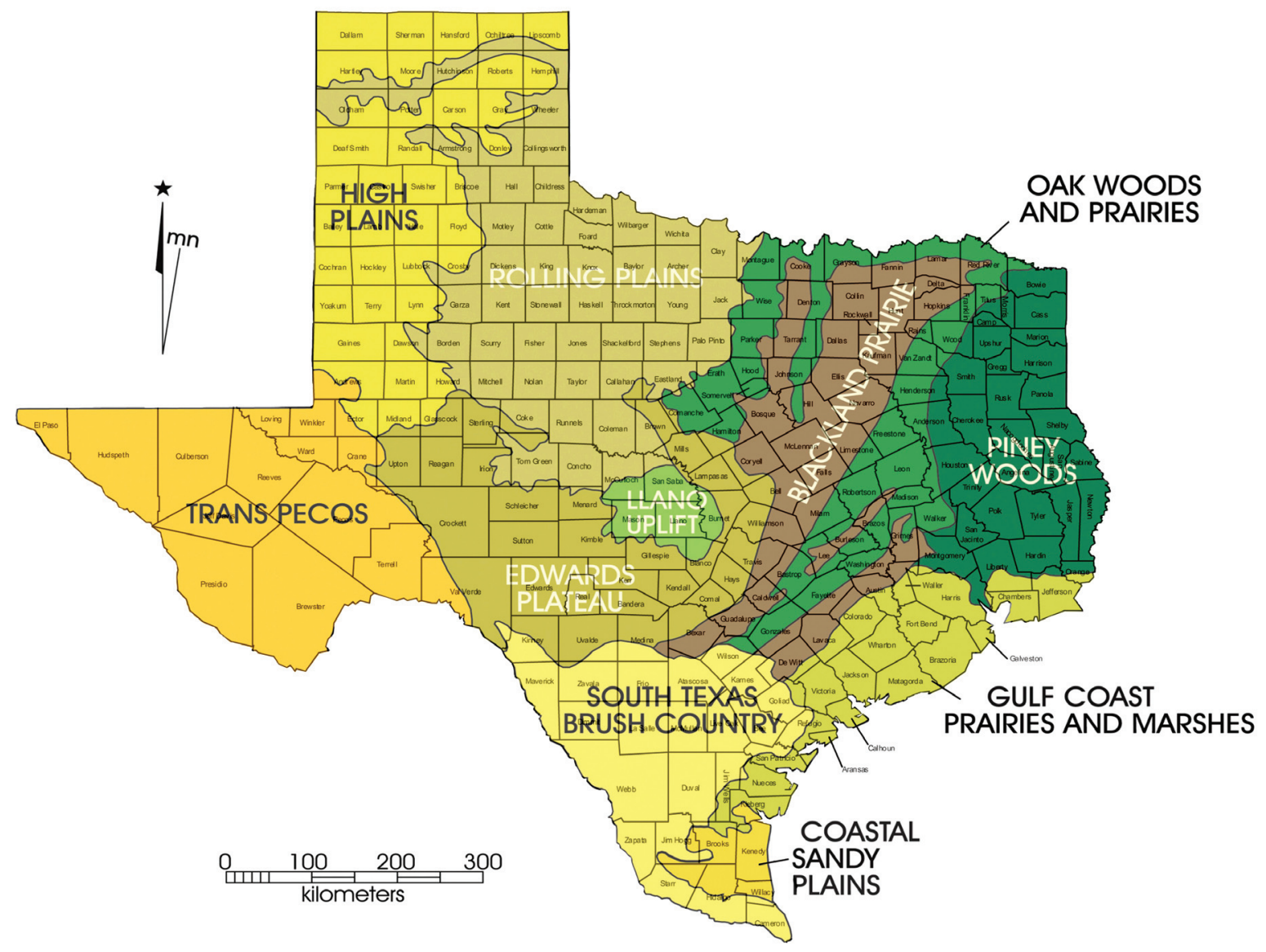

Figure 2-1. Physiographic Regions of Texas. 
and 3036. The area is also served by the Gulf Intracoastal Waterway.

\section{Geology and Soils}

Aransas County is located on the Live Oak Peninsula within the Coastal Prairies physiographic region of Texas (Figure 2-1). Live Oak Peninsula formed during the Pleistocene as part of a mainland shoreline that developed seaward as a result of a series of accumulated sandy beach ridges (Brown et al. 1976). Geology of the area consists of Pleistocene Beaumont Formation barrier island and beach deposits (Barnes 1975; Brown et al. 1976). Altitudes of the area range from sea level to $15 \mathrm{~m}$. Level areas are part of the Coastal Prairie, and are generally poorly drained. Dark, saline, loamy soils cover much of the inland terrain, and sandy beaches occur along the coastal areas. The northwest portion of the county is characterized by loamy, acidic soils, with cracking, clayey subsoils. Soils in the project area consist of Galveston-Mustang Association composed of level to undulating sandy soils on duned coastal plains (Guckina and Carcia 1979). Archaeological site preservation is influenced by proximity to shorelines, sea-level elevations, tropical storms, and hurricanes in addition to wind and wave action.

\section{Vegetation}

The Gulf marshes areas of the county contain cordgrasses, sedges, rushes, seashore saltgrass, marsh millet, and maiden cane. Further inland, native flora consists of tall prairie grasses characteristic of the Gulf prairie and hardwoods, such as elms and oaks, which are found particularly along streambeds. The northern portion of the county is in the Aransas National Wildlife Refuge. Between 11 and 20 percent of the land in the county is considered prime farmland and is utilized as such.
The project area is characterized by short dense grass, elm and oak hardwoods, and tall pine trees. Ground visibility in the area of backhoe trench excavations is approximately 50 percent, while ground visibility in the area of shovel test unit excavation is zero, due to the presence of dense short grass.

\section{Climate}

Aransas County is characterized by a subtropical-humid climate that consists of mild winters and warm summers. Temperatures range in January from an average low of $46^{\circ} \mathrm{F}$ to an average high of $63^{\circ}$, and in July from $76^{\circ}$ to $91^{\circ}$. The average annual rainfall is $14 \mathrm{~cm}$; the average relative humidity is 95 percent at 6 A.M. and 76 percent at 6 P.M. The growing season averages 305 days a year, with the last freeze in early February and the first freeze in mid-December.

\section{Nearby Sites}

A review of the online database of the THC's Texas Archeological Sites Atlas (Atlas) was conducted prior to fieldwork. The Atlas was consulted to identify any previously recorded historic or prehistoric archaeological sites and archaeological surveys located in or near the project area. The Atlas research also included a review of neighboring NRHP properties, SALs, Official Texas Historical Markers (OTHMs), Registered Texas Historic Landmarks (RTHLs), cemeteries, and local neighborhood surveys.

One previously recorded archaeological site was identified approximately $700 \mathrm{~m}$ to the southeast of the Fulton Mansion State Historic Site. Site 41AS50, the Blink Bonnie Campsite, a prehistoric campsite was originally identified by Martin and Potter during their 1927-29 survey of the Texas Coast (Martin 1930). In addition to the archaeological surveys conducted by Martin and Potter between 1927 and 1929, a survey of 


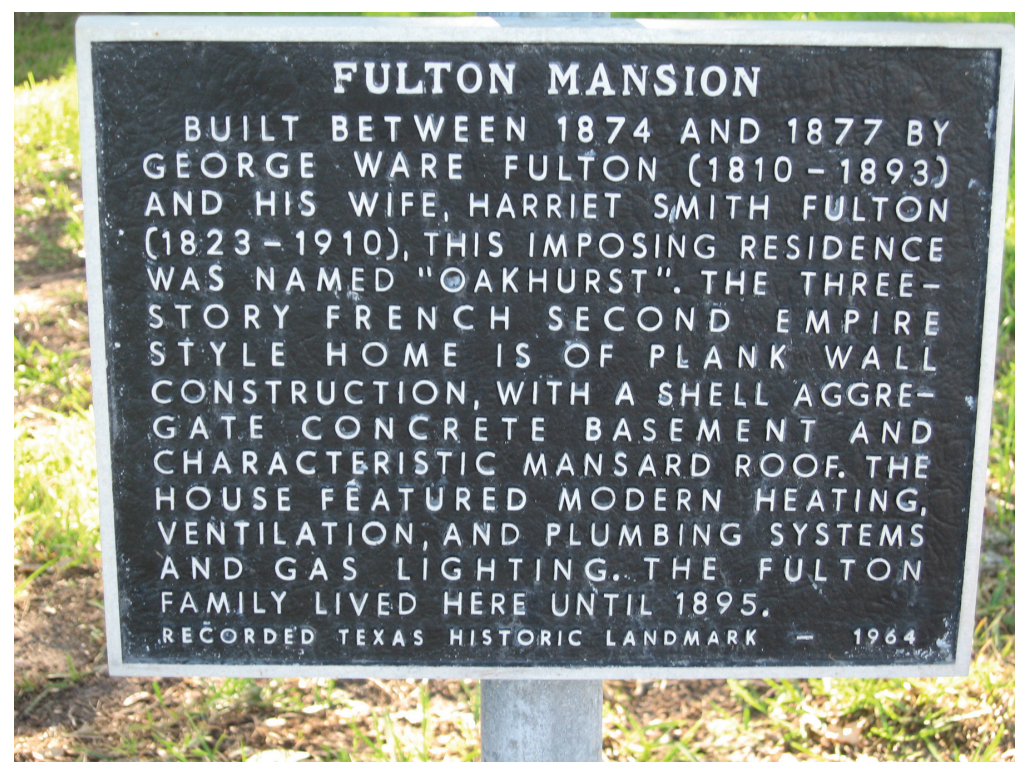

Figure 2-2. Fulton Mansion Historical Marker.

approximately 2.5 miles $(4 \mathrm{~km})$ of pipeline rightof-way was conducted approximately 1300 meters to the northwest of the Fulton Mansion State Historic Site by James Warren in 1988 (THC Archeological Sites Atlas). This survey failed to identify any significant cultural resources. An archaeological linear survey was conducted by TxDOT in 2002 along Business 35 approximately $830 \mathrm{~m}$ southwest of the Fulton Mansion State Historic Site; no cultural resources were identified (THC Archeological Sites Atlas).

Two historical markers are located within $1000 \mathrm{~m}$ of the project area. The historical marker for the Marion Packing Company is located approximately $950 \mathrm{~m}$ to the north of the Fulton Mansion State Historic Site at the corner of Chaparral Road and Fulton Beach Road. The marker indicates the location of the ruins of a rendering vat of the Marion Packing Co. (spelled "Meriam" in some records), one of several meat packing plants built in the Rockport-Fulton area in the 1860 s and 1870 s to process the huge herds of range cattle that roamed the area following the Civil War. Beef was dried, salted, or pickled here before shipping. The by-products such as tallow, hides, horns, and bones were sent to eastern factories. The Marion Packing Co. flourished until about 1880, when shipping cattle to northern markets proved more profitable.

The Fulton historical marker is located approximately $1000 \mathrm{~m}$ to the northwest of the project property in front of the Fulton City Hall at 205 N. 7th Street. This marker designates the City of Fulton as having a history closely associated with the fishing and shipping industry due to its location on Aransas Bay. The town was founded in 1867 by George Ware Fulton, whose mansion is an important local landmark. Schools, churches, and businesses were quickly established in the

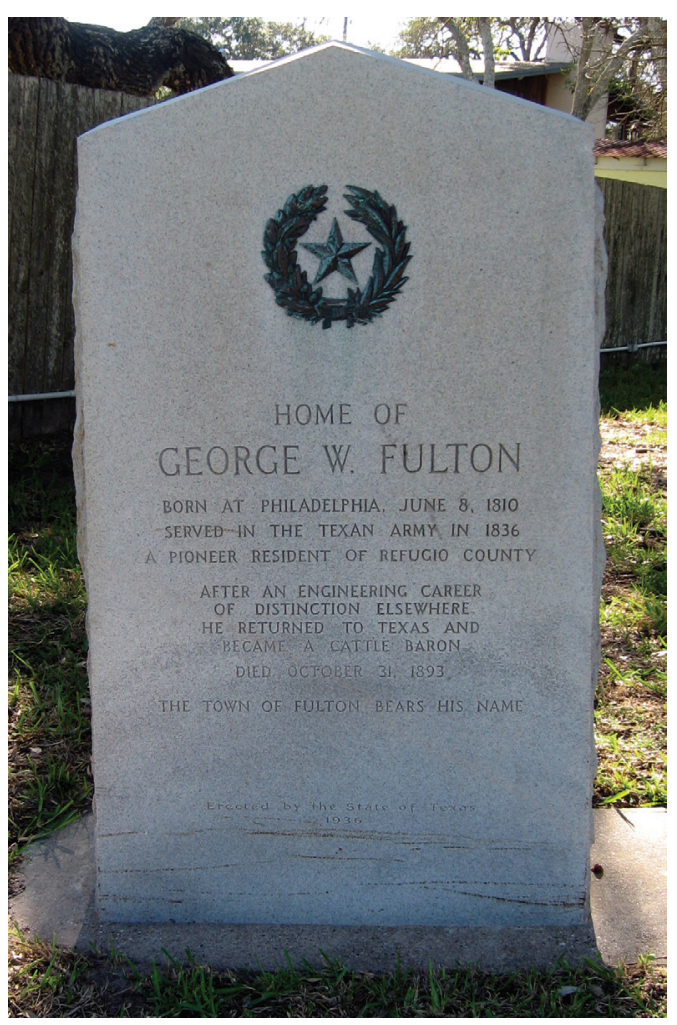

Figure 2-3. George W. Fulton Historical Marker. 
town. A one-room schoolhouse, built in 1886, was relocated and adapted for use as a city hall. In recent years tourism, and commercial fishing and shrimping have become the city's most important economic pursuits. The City of Fulton was incorporated in 1978.

Historical markers for the Fulton Mansion and for George W. Fulton are located on the project property grounds. Photographs of the markers and their associated text are presented in Figures 2-2 and 2-3. The Fulton Mansion was listed on the National Register of Historic Places in 1975 and as a State Archeological Landmark in 1983.

Two cemeteries are also located in the area. The Rockport Cemetery is located approximately $1200 \mathrm{~m}$ to the south of the project area and the Fulton Cemetery is located approximately 1400 $\mathrm{m}$ to the north. George W. Fulton and his wife are buried in the Rockport Cemetery (Figure 2-4).

\section{Previous Investigations}

In 1978 the Historic Sites and Restoration Branch of TPWD conducted monitoring and test excavations on the grounds of the Fulton Mansion State Historic Site (McClenny et al. 1978). The project involved the removal of 35 concrete trailer pads and test excavations on proposed parking and vegetation screening zones. Test trenches were also excavated at four locations around the exterior of the mansion's foundations. Investigations uncovered the remains of the original asphalt driveway, three shellcrete flowerbed borders, a rectangular shellcrete foundation, the builder's trench around the mansion and an early crushedshell walkway (McClenny et al. 1978).

In January of 2007, TPWD conducted test excavations for the proposed Fulton Mansion Visitor's Center (Ringstaff 2008). These testing excavations were prematurely terminated due to rain, rising water table, and the transfer of the property to the Texas Historical Commission. However, results of the testing project revealed the presence of intact subsurface features representing animal carcass refuse disposal. These features primarily consisted of disarticulated Cheloniidae (Sea Turtle) that exhibited butchering marks. These features were linked to a poorly understood segment of the local economy: a regional nineteenth century turtle fishery. In addition to the fauna deposits, a layer of imported fill, extending approximately $45 \mathrm{~cm}$ below surface was also noted. This fill was only present within the immediate footprint of the proposed visitor center and not noted in the single shovel test unit excavated on the Mansion's grounds, east of the proposed visitor center location. Additional details concerning the results of the 2007 investigations are presented in Chapter 4, under Results: Previous Investigations.

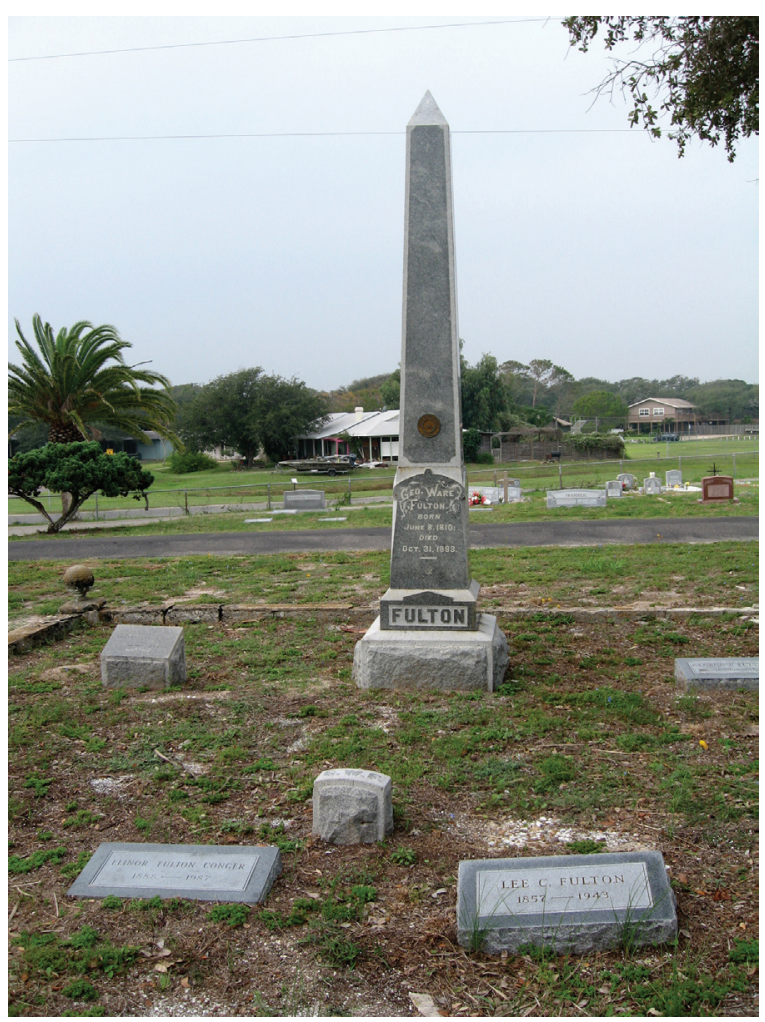

Figure 2-4. George W. Fulton cemetery marker. 
Despite the premature termination of the 2007 testing project, sufficient data was generated to interpret the presence, integrity, and association of the area as an extension of 41AS79 (Ringstaff 2008). Ringstaff determined that the visitor's center APE constituted an expanded boundary of site 41AS79. Cultural deposits encountered during test excavations contained a high probability of direct association with the George W. Fulton occupation of the Fulton Mansion. Ringstaff (2008) concluded that the archaeological deposits and features uncovered along with the potential for additional features and deposits make the extension of 41AS79 within the APE a contributing element to the NRHP listed Fulton Mansion under Criterion D (36 CFR 60.4). Ringstaff (2008) further stated that ground disturbing activities associated with construction of the visitor's center constituted an adverse effect (36 CFR 800.5) to this contributing element of the listed property and designated SAL (13 TAC 26).

Based on previous archaeological investigations within the project area, there exists a high probability that cultural deposits will be encountered during current investigations. Although the nearest previously recorded archaeological site, the Blink Bonnie Campsite 41AS50, lies approximately $700 \mathrm{~m}$ to the southeast of the project area, the location of the Fulton Mansion in proximity to Aransas Bay is coincident with the location of several recorded prehistoric archaeological sites along the coastline of Live Oak Peninsula. A chippedstone projectile point was recovered from the mansion's flowerbeds in the 1980s and is currently housed at the TPWD Archeology Lab (Ringstaff 2008). Notwithstanding this find, the potential for buried prehistoric cultural remains in addition to historic cultural remains is great.

\section{Cultural Chronology}

The study area lies within the Central Texas Coast physiographic province. This area is defined as encompassing the shoreline (including barrier islands) and the coastal plain forty to fifty kilometers inland between the Colorado River to the north and the northern portion of Baffin Bay to the south (Ricklis 2004). The culture history of the region is divided into the Paleoindian, Archaic, Late Prehistoric, and Historic periods.

\section{Paleoindian}

The Paleoindian period, occurring 12,000 to 9000 years ago, encompasses the earliest presence of humans on the North American continent. This period is characterized by a variety of large, wellmade dart or spear points and other various lithic tools associated with now extinct Pleistocene mammals. Subsistence strategies focused on the hunting of these now extinct mammals (Ricklis 2005). Identified Paleoindian sites within the Central Texas Coast region consist of only surface finds (Hester 1980); intact subsurface deposits have not yet been identified within the region. Intact deposits may now be submerged as sea levels were considerably lower during the Paleoindian period (Ricklis 2005).

\section{Archaic}

The Archaic period spans from ca. 75008000 years ago to ca. 900 years ago. This period is characterized by a broad-based hunting, fishing, and plant gathering adaptation (Ricklis 2005). This time period is further divided into the Early Archaic (ca. 7500 to 4200 B.P.) and the Late Archaic (ca. 3000 to 1200/900 B.P.). The earliest evidence of human occupation in the area comes from sites located around Nueces Bay, with radiocarbon dates on oyster shell deposits dating to between 7500 and 6800 B.P. The abundance of oyster shell indicates the utilization of this 
resource as a food source. Edge-flaked sunray venus clamshells used as knives or scrapers is a characteristic tool type of this region and time period. Between 5900 and 4200 B.P. sites became more abundant, suggesting an increase in populations and exploitation of resources along the coastline (Ricklis 2005). There appears to be a hiatus in occupation along the coastline between 4200 and 3000 B.P., which may have resulted from rapidly rising sea levels that inundated the marshes and lagoons of the area (Ricklis 1993, 1995, 2005; Ricklis and Cox 1991; Ricklis and Blum 1997).

Several sites dating to the Late Archaic period have been identified in the region. Dart points that are characteristic of this time period include Kent, Godley, Marcos, Ensor, Matamoros, and Catan types (Suhm and Jelks 1962; Turner and Hester 1993). Shell tools also appear in abundance and include edge-flaked venus sunray clamshells, perforated oyster, whelk hammers, bi-pointed whelk columellae, and conch shell adzes (Ricklis 2005). The first ceramic vessels in the region appear towards the end of the Late Archaic, between ca. A.D. 500 and A.D. 1050 (Ricklis 1996, 2005; Ricklis and Cox 1991). During the Late Archaic inland sites appear to be occupied for only short durations while seaward sites appear to be more intensively used or frequented. These seaward sites may have been seasonal base camps at which large populations may have aggregated to exploit seasonally abundant resource zones. In addition to molluscan resources, fish and deer faunal remains have also been identified within Late Archaic deposits, indicating utilization of these resource types (Ricklis 2005).

\section{Late Prehistoric}

The Late Prehistoric time period, ca. A.D. 1000 to A.D. 1500 is characterized by the appearance of arrow points, small unifacial chert end scrapers, cylindrical flaked chert drills/ perforators, prismatic blade-core chert-knapping technology, and abundant sandy paste pottery often decorated with asphaltum. Bone and shell tools and ornaments in addition to ceramic pipes are also noted (Story 1968; Ricklis 1990, 1992, 1995, 2005). The Rockport Focus is the best known Late Prehistoric culture of the region. Diagnostic artifacts of this focus include Perdiz points, unifacial end scrapers, prismatic blades, thin bifacially flaked knives, and regionally unique sandy paste Rockport ware ceramics. While the Perdiz point occurs throughout most of Texas between A.D. 1250/1300 and A.D. 1700, Rockport ware ceramics are restricted to a narrow zone (about $40 \mathrm{~km}$ wide) along the coast (Ricklis 1996, 2005). Ricklis (2005:13) contends that the Rockport Focus is largely, if not entirely, the archaeological correlate of the Karankawan Indian tribes that have been documented on the central Texas coast in historic times.

Two site types appear during the Late Prehistoric within the Central Texas Coast region. Group 1 sites are characterized by large dense midden deposits in optimal shoreline fishing locations. While terrestrial faunal remains are identified within these sites, fish remains occur in abundance. Group 1 sites appear to have been occupied in the fall through the early spring and suggest intensive fishing activities. Group 2 contrast with Group 1 sites in that they are usually located near bayheads and on upland margins bordering streams. These thinner and smaller cultural deposits consist mostly of deer and bison with infrequent amounts of fish and shellfish. Group 2 sites were occupied from midspring into summer and were primarily utilized for the hunting of large game (Ricklis 2005).

\section{Historic}

The Historic period of the region begins with the mapping expedition of Alonzo Àlvarez de Piñeda who sailed along the Gulf Coast from 
Veracruz, Mexico to the west coast of Florida in 1519. In 1528 Àlvar Nuñez Cabeza de Vaca and three companions were marooned on the Texas Gulf Coast. These four survivors of the ill-fated Narváez expedition lived for six years amongst the coastal Indians before making their way over land to the western coast of Spanish Mexico. The next Europeans to traverse the area were a group led by the French explorer Rene Robert Cavalier, Sieur de la Salle. His chronicler, Henri Joutel recorded their presence along Mustang and Padre Island in January of 1687 (Foster 1998). La Salle established his short-lived Fort Saint Louis on Garcitas Creek near present-day Port Lavaca. Upon hearing of the French incursion into Spanish territory, Governor Alonzo de Leòn sent four unsuccessful expeditions to locate and destroy the French settlement. A fifth and final expedition located the remains of the fort in 1690, which had been destroyed with most of its inhabitants killed by local Indians (Foster 1998).

In 1766, the governor of Coahuila, Diego Ortiz Parilla lead an expedition from San Juan Bautista on the Rio Grande northeast to La Bahia and then down the coast to the Rio Grande. The first detailed descriptions of St. Joseph, Mustang, and Padre Island resulted from this expedition as well as the naming of Corpus Christi Bay. Corpus Christi Bay was explored further in 1747 by Joaquin Prudencio de Orobio y Basterra, commander of the La Bahiá Presidio. By the $1760 \mathrm{~s}$, ranchers ventured north from modernday Tamaulipas, Mexico and began settling the Nueces River valley. The Spanish government attempted to establish a fort at Live Oak in the late 1700s, but Indian encroachments and its desolate location prevented it from taking a foothold. At about the same time, however, the Spanish established a customhouse across from presentday Aransas County on Copano Bay named El Copáno (Freeman 1995).
The area was abandoned by the Mexican ranchers in the early 1800 s due to continued attacks by Comanche and Lipan raiders. The treaties of 1824 allowed for continued ranching of the area and in 1828 the area that is now Aransas County became part of a Spanish empresario grant to James Power and James Hewetson, who agreed to bring both Mexican and Irish settlers to the region. John McMullen and James McGloin also received empresario contracts to settle families along the edge of the Nueces River in 1828 and settlement in the region continued to thrive. A trading post and fort was established by Henry Kinney in 1839 on Corpus Christi Bay (Freeman 1995).

Following the independence of Texas from Mexico, present-day Aransas County was encompassed by what was then Refugio County. Raids by Comanche, Karankawas, and Mexican outlaws continued into the 1830s and 1840s, resulting in the complete abandonment of the region. It was not until Texas achieved statehood that the area began to develop as a populated area. A major contributor to the development of the area was the establishment of the Aransas Railroad Company in the 1840s (Long 2009).

The area that was to become Aransas County was the site of several battles during the Civil War. In February 1862, Union marines landed on St. Joseph Island and destroyed Aransas. By the following summer, the island was deserted. Battles continued both on and off shore as the Confederacy tried to retain a hold of the port area for smuggling the all-important cotton crop. This prime shipping location became the impetus for wealthy cattlemen to utilize Aransas County following the Civil War as a major shipping point for cattle raised in nearby Fulton and Rockport (Long n.d). 


\section{Historical and Architectural Significance of the Fulton Mansion}

George W. Fulton was born in Philadelphia in 1810 and came to Texas in 1837 to assist in the Texas fight for independence. He was employed in the General Land Office following the war and was befriended by the former provisional governor of Texas, Henry Smith. Fulton married Smith's daughter, Harriet in 1840. During this time he was appointed collector of customs for the Aransas district by President Sam Houston and accumulated large tracts of land. Fulton returned to the east in 1846 with his family and remained there for over twenty years where he worked as a reporter in Baltimore, designed bridges in association with John A. Robeling, the designer of the Brooklyn Bridge, and worked as a supervisor for various Northern railroads. Following the Civil War, the Fultons returned to Texas to claim Harriet's vast inheritance. By 1868 George had established the Fulton Wharf Company and the Carruthers-Fulton Packing Company. He even developed an ice machine to preserve beef. Fulton then explored the possibility of connecting the Texas coast with major northern markets. In 1872 he began the construction of his unique mansion which would take four years and an estimated $\$ 100,000$ to complete. In preparation for future development, he carefully planned his own community and named it Fulton. In 1871 George entered into a partnership with Thomas M. Coleman and others to develop the ColemanFulton Pasture Company. George focused on creating a modern a ranching operation and promoted the commercial development of the Coastal Bend of Texas. In the promotion of the meat-packing industry in the Fulton-Rockport area, he perfected one of the first refrigeration systems in the United States. The Colemans eventually sold their interest in the company to Cincinnati millionaire, David Sinton, for whom the town Sinton, Texas is named.
By the mid 1880s George's dreams for the Rockport area began to appear premature. The meat packing industry in Texas vanished with the shift of meat processing to Chicago. As a result of this shift in meat processing, in addition to droughts and rail strikes, the Coleman-Fulton Pasture Company declined in value. Undaunted by these setbacks, George pressed on in the development of the area. He hoped to make the town bearing his name a major deep-water channel port and helped shape the Aransas Pass Harbor Company. George devised methods to reduce silting of dredged out channels and then tried to get federal support to dredge a channel across the Aransas bar, but he passed away before seeing his dream come to fruition. The deep water channel serving the Aransas-Rockport area and the port city of Corpus Christi was finally completed in the 1920s. George W. Fulton died in 1893 and the control of his vast ranching operations was assumed by Cincinnati industrialist David Sinton and his son-in-law, Charles Phelps Taft. It became known as the Taft Ranch and the last of its holdings were eventually sold by 1930 (NRHP \#75001945; McClenny et al 1978).

Colonel George Ware Fulton and Harriet Gillette Smith built the Fulton Mansion, overlooking Aransas Bay between 1874 and 1877 from plans designed by Fulton himself. The three-story Second Empire style mansion was raised five feet above grade over a onestory, full basement which contained a kitchen, food storage, a laundry, and other daily support facilities. Though he utilized a contractor from New Orleans, George Purvis, Fulton's knowledge of construction allowed him to engineer the elaborate water and mechanical systems of the home, as well as conceive the structural technique that enable the building to withstand over 100 years of harsh salt-water elements and hurricanes. No other structure of this type exists in this area of Texas. The house is of a turreted design with 
a mansard roof and asymmetrical composition. The main entrance was raised a half level about grade to protect against high tides. The residence, dubbed "Oakhurst" by its builders, featured the most up-to-date conveniences for the time, such as indoor plumbing and central gas lighting and heating. The basement walls were formed of poured shellcrete; a thin layer of pink stucco covers the original cement plaster, concealing its scored block appearance. The upper three stories of the mansion are constructed of horizontally laid planks, spiked together to form solid, laminated, structural walls. The floors are constructed in the same manner and are in effect vertical walls laid horizontally. The exterior of the walls are clad with vertical cypress siding with the interior wall faces and ceiling finished with a plaster over wood lath. The entry hall, conservatory, parlor, library, and dining room are located on the first floor while the upper floors contain bedrooms and two bathrooms. Notable interior features and finishes include finely articulated plaster cornice moldings and ceiling medallions; wood and patterned tile floors; marbleized slate mantles; two wood-framed over mantle mirrors; porcelain and marble lavatories; brass door, window, gas, and plumbing fittings; and elegantly molded and paneled woodwork of varnished black walnut and cypress. In addition, a central ventilation shaft, hot air heating system, dumbwaiter, clothes drying apparatus, food chilling troughs, and carbide gas and interior plumbing systems were incorporated into the mansion for the comfort and convenience of its residents (NRHP \#75001945; McClenny et al. 1978).

Harriet Fulton retained residence at the mansion following the death of her husband until 1896. In 1906, the mansion and the 60 acres of land upon which the mansion stood was deeded to the Fulton children. The property was then sold by the children in 1907. Much of the 60 acres of land surrounding the mansion was divided into individual lots and sold off during the Depression. In the 1950s the mansion was used as a restaurant and the remaining surrounding property was used as a trailer park in the 1960s and 1970s. The mansion was added to the National Register of Historic Places in 1975. According to the NRHP Inventory form the house was nominated with applicable criteria of architecture/engineering and person with the areas of significance being community planning and development, architecture, and invention. The State of Texas purchased the mansion and 2.3 acres (0.93 ha) of land in 1976 on behalf of the Texas Parks and Wildlife Department with restoration work commencing in 1978. The Fulton Mansion State Historic Site was opened to the public in 1983. On January 1, 2008, the Fulton Mansion was transferred from the Texas Parks and Wildlife Department to the Texas Historical Commission and is now operated as the Fulton Mansion State Historic Site.

\section{Turtle Fishing and Canning Industry}

Doughty (1984) notes a dramatic increase in the commercial fishing industry of coastal Texas in the $1880 \mathrm{~s}$, an increase that is partially attributed to the rise of commercial sea turtle fishing and canning in the Fulton/Rockport area. Sea turtle ranked tenth among fishing products from the Gulf States during this period, but fifth in Texas. The most commonly found and most widely distributed sea turtle along the Texas coast at this time was the green sea turtle (Chelonia mydas). By 1892, the industry took a sharp decline, most likely a result of over fishing (Doughty 1984).

The consumption of sea turtles is noted among the Native American Indians who inhabited coastal Texas. The Karankawa hunted 
sea turtle and boiled them in earthen pots or roasted them (Hammond 1891). By 1840, the Karankawa population had been replaced by Anglo-American settlers who targeted what appeared to be an endless supply of sea turtle. Local commerce eventually focused on sea turtle fishing in part due to a decline in the agricultural economy (Doughty 1984). By 1880, 24,000 lbs of green turtle was commercially fished in Texas coastal waters, an amount that was still substantially less than crab and oyster catches (Doughty 1984). However, commercial fishing of sea turtle increased dramatically from 1880 to 1890 as part of an overall increase of 145 percent in marine products (Doughty 1984). The sea turtle catch in Texas reached an all time high in 1890; a twentyfold increase over the 1880 catch, to approximately $480,000 \mathrm{lbs}$, representing the most sea turtles captured in all the Gulf States (Doughty 1984).

Both shore and vessel turtle fishing employed the use of turtle or gill nets that were often anchored in shallow lagoons (Doughty 1984). These nets were seven to ten feet deep and sixty to one hundred feet long. The nets were anchored in channels frequented by sea turtles and would ensnare the heads or flippers of a passing turtle. In Aransas Bay, the months of June until September were considered ideal times for sea turtle fishing; however, catches could be expected as early as May and as late as October (Doughty 1984). The average catch consisted of two to three individuals, but catches of twenty animals a day were not unheard of. The annual income from turtle fishing in the Aransas Bay area in 1890 was approximately $\$ 325$. Fishermen often augmented their income by hunting waterfowl in the winter and gulls, terns, and egrets for the millinery trade in the spring (Doughty 1984).

During the late $1800 \mathrm{~s}$, the sea turtle industry in Texas was concentrated in Aransas Bay. This concentration included the establishment of a cannery in Fulton, in 1881, that solely focused on canning turtle meat. This cannery operated continuously until 1896 (Doughty 1984). Fulton had been well known for its beef processing industry and beef packinghouses located around Aransas Bay began processing green sea turtles in 1869. Between 1865 and the early 1880s, thirteen to fourteen beef packinghouses had been established in the area (Doughty 1984). The wastes from these packinghouses were reported to have attracted large shoals of fish and carnivorous sea turtles.

The Fulton Cannery reportedly processed 900 green turtles consisting of $243,000 \mathrm{lbs}$ of turtle meat, resulting in 40,000 two-pound cans of turtle meat in 1890 (Doughty 1984). This facility processed 36.7 percent of the reported sea turtle catch in 1889 and 41.7 percent in 1890 (Doughty 1984). The remainder of the Texas catch was consumed locally or sold to traders. Sea turtles were caught by local fishermen and shipped to wholesalers in Galveston who would often ship the trussed sea turtles live to New York (Doughty 1984). The establishment and expansion of the turtle canning industry in Texas eventually resulted in the decline of the price of sea turtle meat, ultimately amounting to barely three percent of the dollar value of all commercial fishing products in Texas by 1890 (Doughty 1984). In Aransas Bay, fisherman received between one and three cents a pound for sea turtles; with the average green sea turtle weighing approximately 270 pounds this resulted in $\$ 2.70$ to $\$ 8.01$ per turtle (Doughty 1984).

In order to keep the sea turtles alive, and to await premium prices or shipment to lucrative markets, the local fishermen would construct "crawls". These marine pens were about 100 to 500 square feet in area and constructed by driving wooden stakes into the sand a few feet apart in 
about six feet of water (Doughty 1984). The poles were strung together to provide strength and the turtles were hauled out by block and tackle, often butchered on the wharf, or flipped on their backs and trussed for transport (Doughty 1984).

By the late 1890s, the turtle fishing industry in Texas experienced a steep decline (Doughty 1984), almost certainly as a result of overfishing. In 1898 a federal study by C.H. Townsend reported that "no drying, pickling, smoking, or canning of fishery products along the Texas coast," were evident, indicating the total collapse in the green sea turtle industry (Townsend 1899). The Fulton Cannery was closed in 1890 and was reported to have moved operations south to Tampico (Doughty 1984). This closure, no doubt, was the result of over fifteen years of commercial fishing on the Texas Gulf Coast, in which over 900 green sea turtles were processed annually just by this cannery alone. In addition to those processed by the Fulton Cannery, hundreds of other sea turtles were consumed by local residents each year. The sharp decline caused one expert to note that the sea turtle would have to be "artificially propagated" in order to survive (Doughty 1984:64). The decline in sea turtles brought on by the turtle fishing industry resulted in legislation in 1895 that required licenses for catching green turtles and terrapins (e.g., Malaclemys terrapin, the diamondback terrapin) (Doughty 1984, Park 2000). By 1900, the Texas turtle fishing industry was virtually nonexistent (Doughty 1984). 


\section{Chapter 3}

\section{Methods}

Carole Leezer and Julian A. Sitters

\section{Project Goals}

The initial objectives of the project were to determine the presence of archaeological resources within the APE and evaluate any resources under Section 106 of the National Historic Preservation Act of 1966 (NHPA) for eligibility for listing to the National Register of Historic Places (NRHP) (36 CFR 60.4) in addition to the potential to be contributing elements to the Fulton State Archeological Landmark (SAL). Recommendations are to be presented to the Texas Department of Transportation (TxDOT) and the State Historic Preservation Officer (SHPO) under terms of first amended Programmatic Agreement among FHWA, TxDOT, the Advisory Council on Historic Preservations, and the Texas SHPO (2005), and the Memorandum of Understanding between TxDOT and THC. The current project is conducted as an addendum to the previous investigations conducted by Ringstaff in 2007, (2008) and examines the new, previously untested area, while also addressing some recommendations from the earlier project.

In order to meet this objective, CAS focused investigations on the excavation of backhoe trenches within the proposed visitor's center parking lot, in addition to providing archaeological monitoring of a cable internet line between the proposed visitor's center and the mansion. The secondary purpose of the excavation of backhoe trenches within the parking lot area was to determine whether additional cultural deposits are similar to those previously encountered in the area of the proposed visitor's center. The project scope was expanded to include shovel test investigations in advance of an irrigation system installation. The primary object of this portion of the project was to provide regulatory clearance under the Texas Antiquities Code in addition to determining whether the modern fill layer identified by Ringstaff (2008) was present within the mansion property grounds.

\section{Background Review}

Prior to commencing field work, a background review was conducted to gather information necessary to conduct investigative work. Information was drawn primarily from Interim Report for Archeological Testing at Fulton Mansion State Historic Site 41AS79 for the Proposed Fulton Mansion Visitor's Center, Aransas County, Texas (Ringstaff 2008), and the online database of the THC's Texas Archeological Sites Atlas (Atlas). The Atlas was consulted to identify any previously recorded historic or prehistoric archaeological sites and archaeological surveys conducted in or near the project area. The Atlas research also included a review of neighboring NRHP properties, SALs, Official Texas Historical Markers (OTHMs), Registered Texas Historic Landmarks (RTHLs), cemeteries, and local neighborhood surveys. 


\section{Fieldwork}

CAS obtained a Texas Antiquities Permit (No. 5420) prior to conducting investigations. CAS conducted investigation of the APE as a continuation of the original testing investigations begun by Ringstaff in 2007 to advise in the final determination of NRHP eligibility. Following the completion of Ringstaff's (2008) report, it was determined in consultation with TxDOT and the SHPO (May 26, 2009, Memo on Proposed Additional Work at the Fulton Mansion Visitor's Center, Aransas County) that additional investigative work was needed. The APE of the proposed visitor's center parking lot is presented in Figure 1-2 and is approximately $260 \mathrm{ft}(80$ $\mathrm{m})$ by $100 \mathrm{ft}(31 \mathrm{~m})$ with an estimated depth of impact of no more than 12 in $(30 \mathrm{~cm})$ below the existing grade.

To mitigate the adverse effects to the cultural deposits associated with the construction of the visitor's center, architectural plans for the proposed visitor's center call for 30 in (76.2 $\mathrm{cm})$ of fill to be utilized as a pad upon which the building will sit. As such, features within the visitor's center's APE will be avoided as the deepest building foundation beam will be 11.4 in $(29 \mathrm{~cm})$ below the current existing grade. Cultural deposits identified by Ringstaff's testing were encountered at approximately 35.4 in (90 $\mathrm{cm}$ ) below the surface. However, an electric line is proposed that will be placed approximately three inches above the level of identified cultural materials.

CAS excavated a backhoe trench, Utility Backhoe Trench (UBHT), in the location of the proposed electric line (see Figure 1-2). The length of the trench was approximately $10 \mathrm{~m} \mathrm{(33}$ $\mathrm{ft}$ ) in length; equal to the length of the proposed electrical line. CAS also excavated two additional backhoe trenches, Western Backhoe Trench (WBHT) and Eastern Backhoe Trench (EBHT), in the area of the proposed parking lot (see Figure 1-2). It was determined prior to field work that construction of the proposed parking lot would not impact any cultural resources if the cultural resources occur at the same depth as those previously encountered by Ringstaff (2008). The reason for excavating backhoe trenches within the parking lot area was to determine whether additional cultural deposits found are similar to those previously encountered in the area of the proposed visitor's center. Backhoe trenches were excavated to a depth of $150 \mathrm{~cm}$ below the surface and extended diagonally (northwest to southeast) across the length of the proposed parking lot. WBHT was approximately $27 \mathrm{~m}$ (89 ft) long and EBHT was approximately $29 \mathrm{~m}(95 \mathrm{ft})$ long. All trench excavations were monitored by a professional archaeologist. All cultural features encountered during backhoe excavations were fully exposed by controlled hand excavations and recorded in their entirety. Controlled hand excavations consisted of two $50-\mathrm{cm}$ by $1-\mathrm{m}$ square test units excavated in arbitrary $10-\mathrm{cm}$ levels until sterile levels were encountered. All sediments were screened through $1 / 4$ inch screen. Soil profiles were recorded for all excavated trenches and excavation units. All collected artifacts were processed, analyzed, and prepared for curation by CAS. They were temporarily housed at the Center for Archaeological Studies at Texas State University-San Marcos and are to be permanently curated at the Texas Historical Commission following the completion of the project.

Archaeological monitoring was conducted in advance of the installation of an underground internet cable line. A professional cable installation company excavated a trench by hand and with a Deere 27 backhoe excavator. The cable line trench was approximately 12 in $(30 \mathrm{~cm})$ wide and 24 in $(60 \mathrm{~cm})$ deep and extended from the southwest corner of the Fulton Mansion south 
to the property boundary, and then west to the visitor's center (see Figure 1-2). A portion of the line consisted of a horizontally bored line placed beneath Nancy Ann Street. The entire excavation process was monitored by archaeologists from CAS to assess the potential disturbance of any archaeological features or remains that may be encountered and to ensure systematic recovery and documentation of artifacts and features if present. The digging process was stopped temporarily upon encountering evidence of intact features or other significant cultural deposits. All encountered features and cultural deposits were recorded. Photographs were taken throughout the excavation of the trench. The excavated trench remained open until the installation of the cable line was completed.

The primary scope of work was expanded to include shovel test unit excavations in advance of a proposed irrigation system installation within the front and side lawns of the mansion property. CAS excavated 20 shovel tests across the front and side lawn portion of the mansion site in order to determine whether the modern fill layer identified by Ringstaff (2008) was present.
Shovel tests measured approximately $1 \mathrm{ft}$ (ca. 30 $\mathrm{cm})$ deep, and $1 \mathrm{ft}(\mathrm{ca} .30 \mathrm{~cm})$ in diameter, and were excavated for the purpose of determining whether or not (1) the modern fill layer was present in the APE or (2) whether the fill layer was absent and intact archaeological materials were present. If intact cultural materials relating to the Fulton Mansion were encountered, CAS would provide recommendations concerning how these deposits might be avoided or protected during the installation of the irrigation system, or for an appropriate level of additional investigations for the purpose of offsetting the loss of important cultural information that will result in the event that the deposits cannot be avoided.

All archaeological investigations were conducted according to guidelines established by the Texas Historical Commission (THC) and the Council of Texas Archeologist (CTA). Results of fieldwork and background review were provided to the Site Supervisor of the THC following the completion of the project. The Sites Supervisor of the THC will provide recommendations of eligibility to TxDOT and the SHPO as a continuation of Section 106 consultation. 


\section{Chapter 4}

\section{Results}

\section{Carole Leezer and Julian A. Sitters}

\section{Previous Investigations}

A total of five backhoe trenches, four test units, and one shovel test unit were excavated during previous investigations of the proposed visitor's center APE by Ringstaff (2008) in 2007 (Figure 4-1). Feature 1, a pit filled with bone, was immediately encountered during the excavation of Backhoe Trench 1. A similar feature, Feature 2, was encountered during the excavation of Backhoe Trench 2 (Ringstaff 2008).

Test Units 1 and 2 were placed over features in Backhoe Trenches 1 and 2 respectively. Test Unit 1, a 1x1-m test unit, was placed in the west end of Backhoe Trench 1 (see Figure 4-1) over

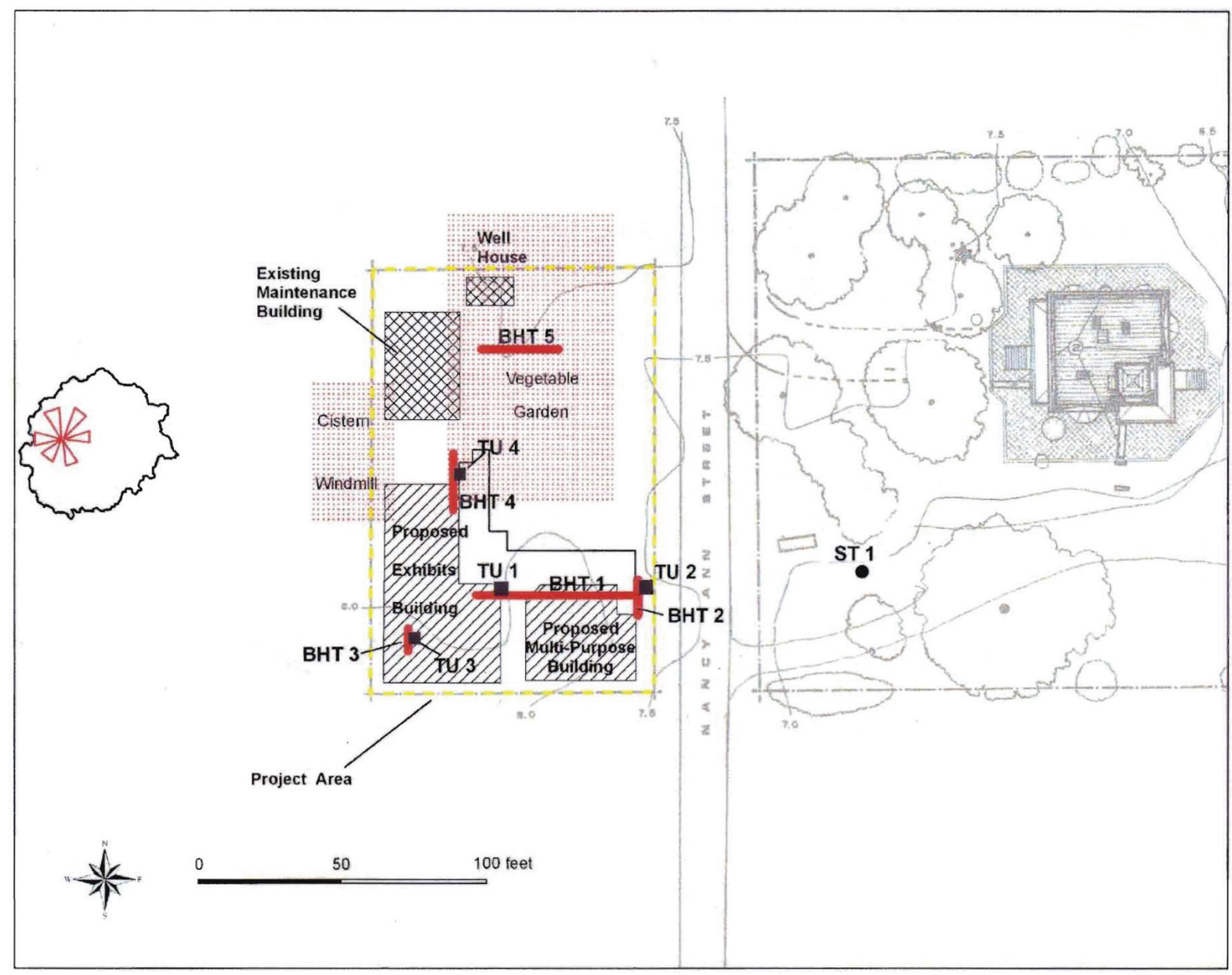

Figure 4-1. Location of Ringstaff's excavations (from Ringstaff 2008; Figure 4). 


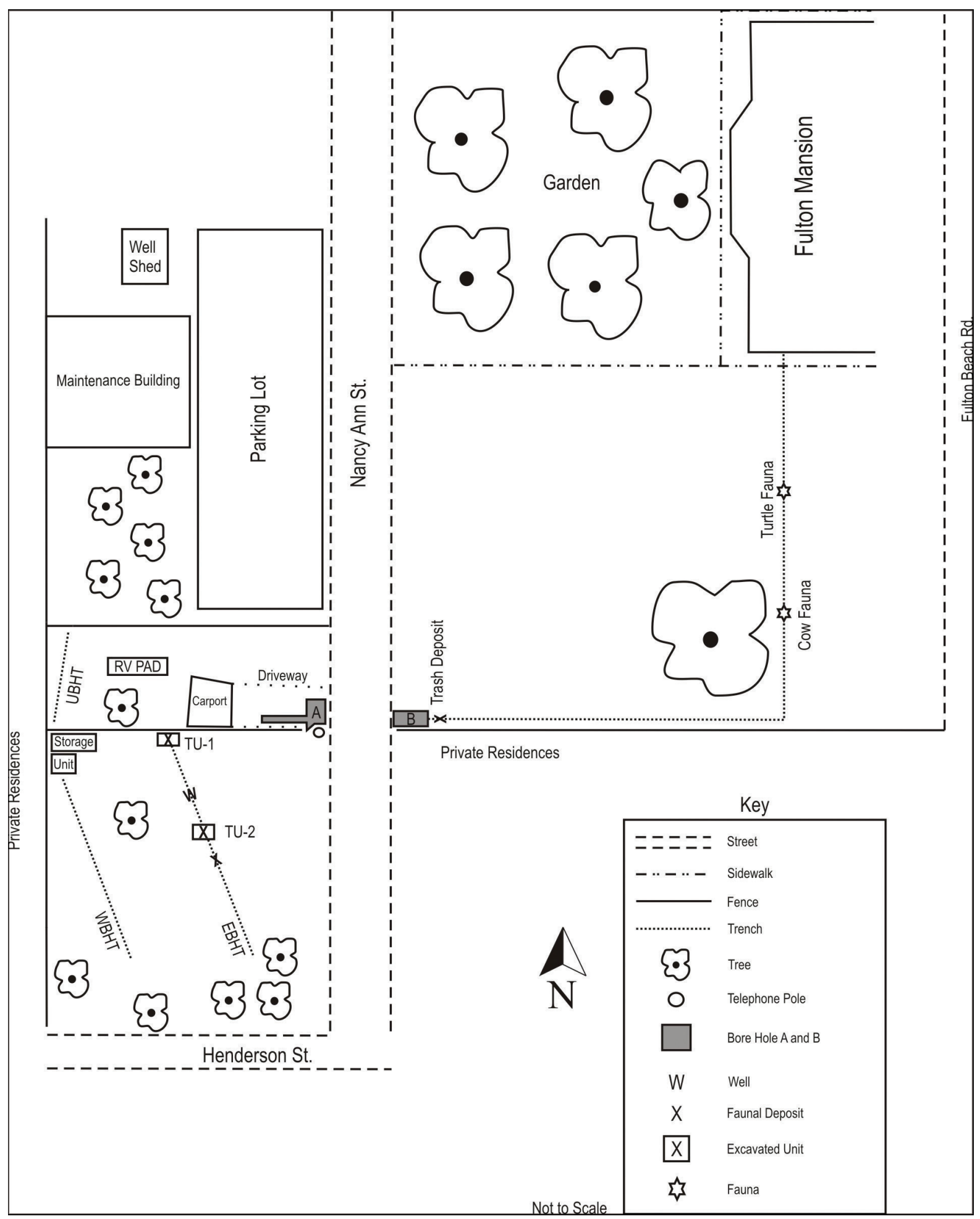

Figure 4-2. Backhoe trenches and internet cable trench location map. 
Feature 1 after it was encountered during backhoe excavation. The upper $40 \mathrm{~cm}$ of the unit was devoid of artifacts and was composed of imported fill. The feature was exposed at approximately $90 \mathrm{~cm}$ below surface (cmbs) and extended to a depth of approximately $116 \mathrm{cmbs}$. The horizontal dimensions of Feature 1 were approximately 81 $\mathrm{cm}$ by $95 \mathrm{~cm}$ with a thickness of approximately $26 \mathrm{~cm}$. Feature 1 consisted almost entirely of sea turtle remains (Cheloniidae) (Ringstaff 2008).

Test Unit 2 consisted of a $1 \times 1-m$ test unit placed in the north end of Backhoe Trench 2 (see Figure 4-1) over Feature 2 after it was encountered during backhoe excavations. Like Unit 1, the upper $30 \mathrm{~cm}$ of Unit 2 contained imported fill devoid of artifacts. Road base and asphalt was documented overlying this fill material in the eastern half of the unit. Feature 2 was also an apparent pit filled with bone. The depth of the feature is unknown due to the inability to fully excavate the feature due to rising water table levels, but its thickness was greater than $10 \mathrm{~cm}$. The horizontal dimensions of Feature 2 were approximately $68 \mathrm{~cm}$ by $83 \mathrm{~cm}$. A third feature, Feature 3, was also encountered in the south wall of Backhoe Trench 1 approximately $15.5 \mathrm{~m}$ east of Feature 1 at a depth of approximately $95 \mathrm{cmbs}$. The feature was not excavated, but noted and mapped. Exposed bone was observed within the feature and consisted of a coracoid and a possible humerus of Cheloniidae (Ringstaff 2008).

Test Units 3 and 4 were arbitrarily placed in Backhoe Trenches 3 and 4 respectively. Test Unit 3, a 50x50-cm test unit, was placed in the central portion of Backhoe Trench 3 (see Figure 4-1). The upper $40 \mathrm{~cm}$ of the unit consisted of imported fill material, and sparse historic artifacts were recovered between 40 and $90 \mathrm{cmbs}$. The upper 40 to $45 \mathrm{~cm}$ of Test Unit 4 consisted of imported fill. Sparse historic artifacts were also recovered from this unit between 40 and $70 \mathrm{cmbs}$ (Ringstaff 2008).

One shovel test unit, Shovel Test 1, was excavated approximately $20 \mathrm{~m}$ to the east of Backhoe Trench 2 (see Figure 4-1). Shovel Test 1 was excavated to a depth of $100 \mathrm{cmbs}$ and a complete absence of imported fill material was noted. A total of ten artifacts were recovered consisting of glass, metal, unknown bone, and coal fragments (Ringstaff 2008).

\section{Current Investigations}

A total of three backhoe trenches, two test units, and twenty shovel test units were excavated during current investigations of the proposed expanded parking lot, electric utility line, and irrigations system. Two backhoe trenches, Western Backhoe Trench (WBHT) and Eastern Backhoe Trench (EBHT), were excavated in the proposed location of the visitor's center parking lot, a 28x30-m area located at the corner of Henderson Street and Nancy Ann Street (Figure 4-2). A third backhoe trench, Utility Backhoe Trench (UBHT), was excavated in the proposed location of an electrical utility line for the new visitor's center. Test Units 1 and 2 were place above faunal bone deposits exposed during the excavation of EBHT. Shovel Test Units 1 through 20 were randomly place on the side and front lawns of the Fulton Mansion property. These units were excavated in advance of a proposed irrigation system to determine whether a modern fill layer was present within the APE or whether the fill layer was absent and intact archaeological materials were present (results of these are discussed below). Archaeological monitoring of a cable internet line installation was also conducted. 


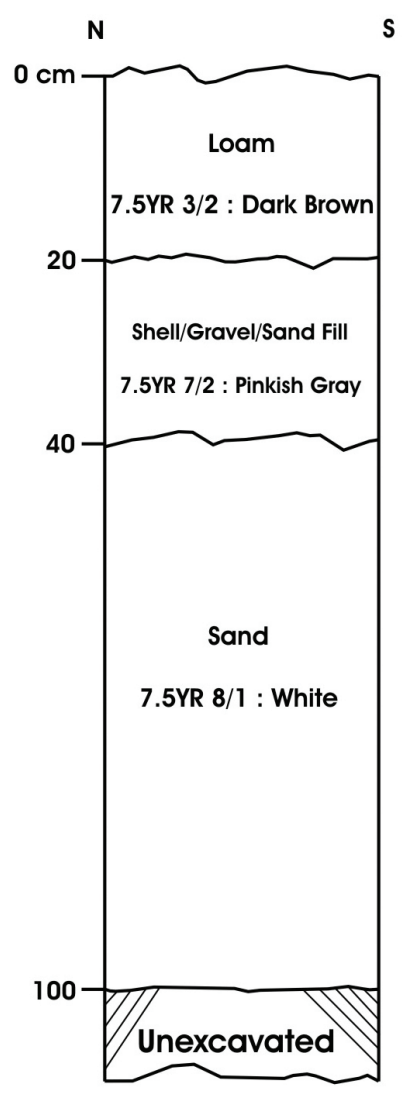

Figure 4-3. Representative profile of the utility backhoe trench.

The additional backhoe trenches, WBHT and EBHT, were excavated in the area of the proposed visitor's center parking lot. While construction of the proposed parking lot will not impact any cultural resources if those resources occur at the same depth as previously identified cultural deposits, WBHT and EBHT were excavated to determine whether possible deposits are similar to those previously documented.

\section{Utility Backhoe Trench (UBHT)}

The Utility Backhoe Trench (UBHT) was excavated to a depth between 90 and $100 \mathrm{cmbs}$. UBHT extended for a length of approximately 10 $\mathrm{m}$; the length of the proposed electric line (see Figure 4-2). A buried water line was encountered at approximately $80 \mathrm{cmbs}$ in the southeastern end of the UBHT. The water line traversed the backhoe trench from the southeastern side of the trench to the northwestern side of the trench and was ruptured during excavations. Excavation was temporarily halted to repair the waterline and then continued in a northeasterly direction to avoid the buried line. Excavations north of the ruptured waterline extended to a depth of $120 \mathrm{~cm}$. An examination of the profile of UBHT indicated

\section{Backhoe Trenches}

The architectural plans for the visitor's center call for 30 in $(76 \mathrm{~cm})$ of fill to be brought in as a pad on which the building would sit in order not to impact cultural deposits. As the depth of the proposed electrical line is estimated to be approximately 3 in $(7.6 \mathrm{~cm})$ above the level of previously identified cultural deposits, the UBHT backhoe trench was excavated in this location to assess possible impacts to cultural deposits.

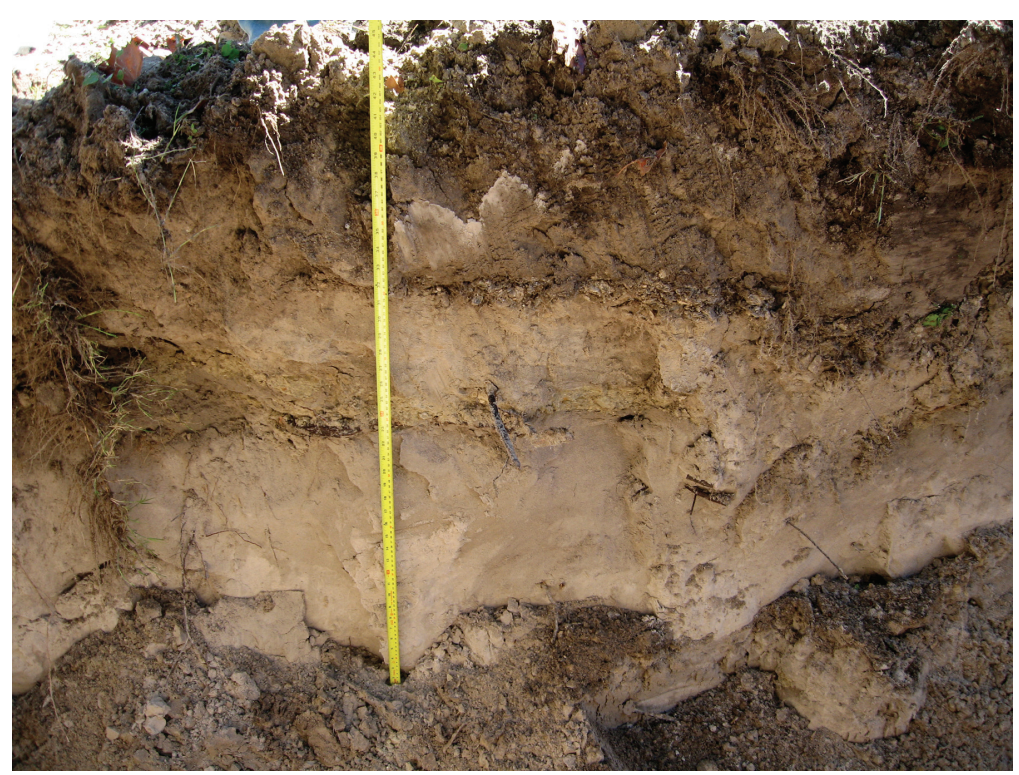

Figure 4-4. Utility backhoe trench profile photo. 
imported construction fill material similar to that noted during previous investigations (Ringstaff 2008) of the area. This construction fill appears at approximately $20 \mathrm{cmbs}$ and extends to approximately $40 \mathrm{cmbs}$, a depth similar to that reported by Ringstaff (2008). This fill layer is overlaid by a dark brown loam extending from 0 to $20 \mathrm{cmbs}$ and overlies a white sand layer that extends from 40 to $100 \mathrm{cmbs}$ (Figure 4-3 and Figure 4-4). No cultural deposits were encountered during excavation of the UBHT.

Western Backhoe Trench (WBHT) and Eastern Backhoe Trench (EBHT)

The Western Backhoe Trench (WBHT) and the Eastern Backhoe Trench (EBHT) were excavated in the proposed location of the visitor's center parking lot. The purpose of the excavation of backhoe trenches within the parking lot area is to determine whether additional encountered cultural deposit are similar to those previously encountered during Ringstaff's (2008) investigation of the proposed visitor's center. As these backhoe trenches contained similar profiles they are described here together.

The WBHT was excavated on the western side of the $28 \times 30-\mathrm{m}$ area of the proposed location of the visitor's center parking lot. WBHT was excavated to a depth of $150 \mathrm{cmbs}$ and extended for a length of $27 \mathrm{~m}$. Three distinct strata were noted in the profiles of both WBHT and EBHT (Figure 4-5). A grayish brown sandy loam layer extends from 0 to $30 \mathrm{cmbs}$, and from 30 to 90 cmbs a light gray sand layer is noted similar to the Zone 1 (A Horizon) noted by Ringstaff in his Test Unit 1 profile. Between 90 and 150 cmbs a very pale brown sand layer is noted, also similar to Ringstaff's profile description. Unlike Ringstaff's profile descriptions, however, both the WBHT and the EBHT lacked a layer of imported fill material.
The first faunal deposit was immediately encountered during the excavation of the EBHT. Deposit 1 was exposed at approximately $80 \mathrm{cmbs}$ in the profile of the northeastern wall of the EBHT (Figure 4-6). Backhoe trench excavations were temporarily halted and Test Unit 1 was placed above the feature. A total of 6,767 fragments and whole (11,477.6 grams) faunal bone were recovered from Test Unit 1 and included cow, green sea turtle, and fish. This deposit is further described in Chapter 5 and Appendices B and C. Backhoe excavations continued following

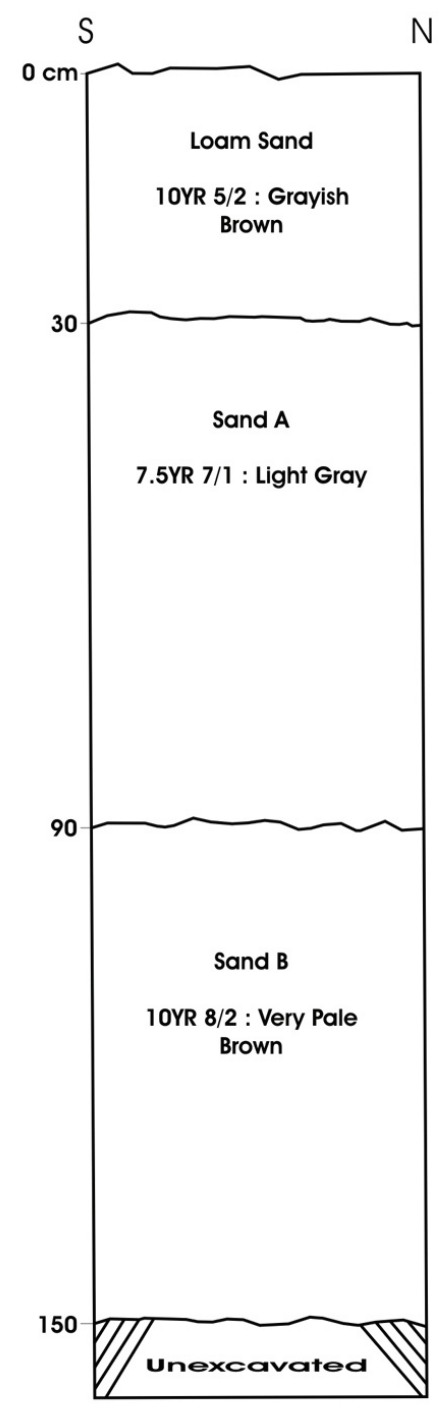

Figure 4-5. Representative profile of backhoe trenches. 


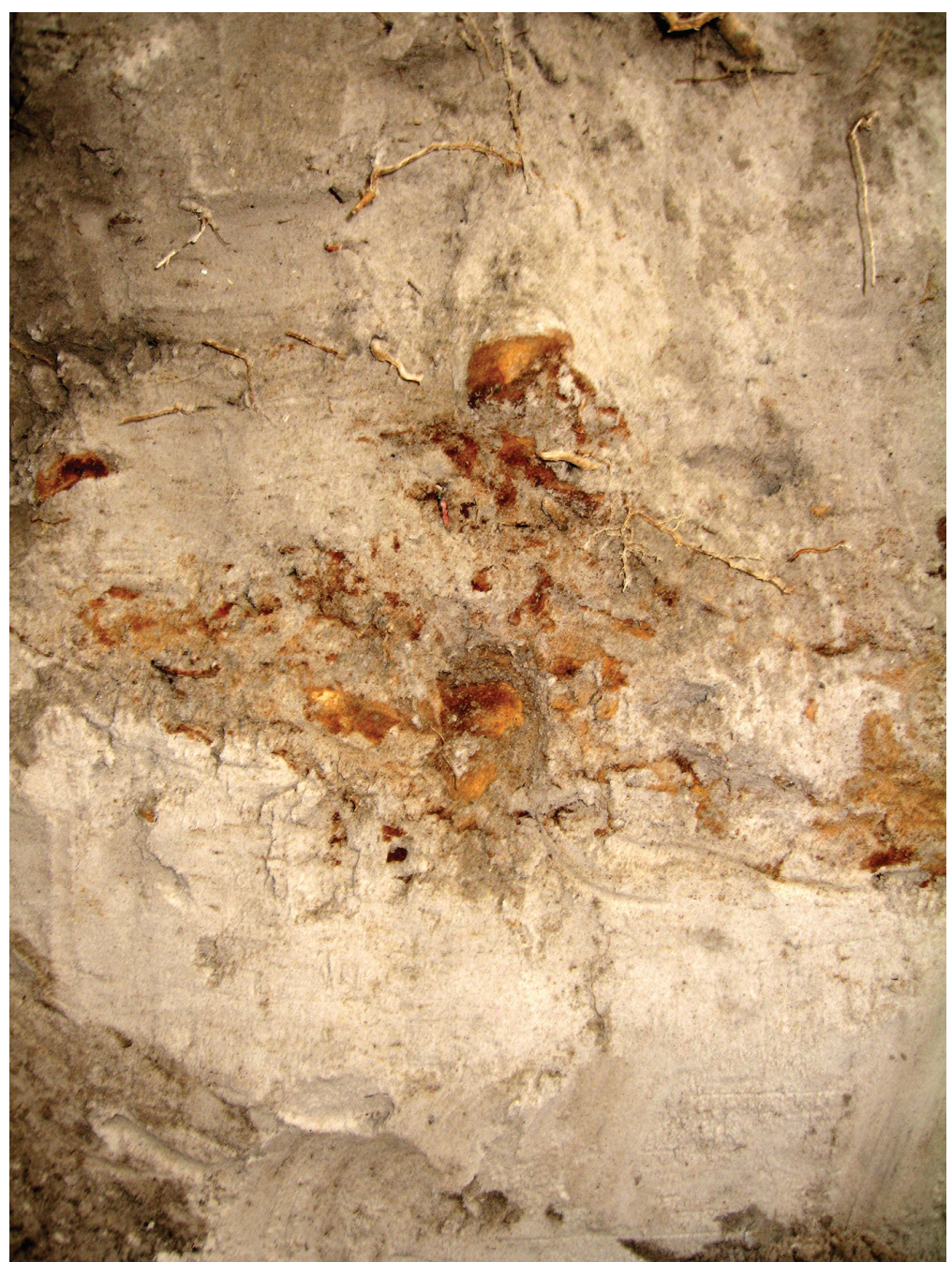

Figure 4-6. Photo of deposit in profile of Eastern Backhoe Trench; facing northeast. Discolored spots are turtle bone. Deposit is located approximately $80 \mathrm{cmbs}$. was exposed at approximately $50 \mathrm{cmbs}$ in the western wall profile of the EBHT. Test Unit 2 was placed above this deposit. The deposits consisted of a total of 1,053 fragments and whole (7,628.9 grams) faunal bone that included green sea turtle and unidentified mammal. This deposit is also further described in Chapter 5 and Appendices B and C. A third deposit, Deposit 3 , was completely excavated by the backhoe during excavation of the backhoe trench and consisted of only sea turtle remains. This deposit was identified in the back fill and was encountered at approximately six meters south of Deposit 2. The depth of this deposit is unknown due to the nature of its recovery. A full analysis of all the recovered faunal deposits is presented in Chapter 5. No faunal or cultural deposits were noted or encountered during the excavation of WBHT.

\section{Shovel Test Unit Excavations}

A total of 20 shovel test units were excavated on the side and front lawns of the Fulton Mansion the hand excavation of Test Unit 1 and a modern well head was encountered at approximately 32 cmbs in the eastern wall profile of the EBHT approximately 10 meters south of Deposit 1. This abandoned modern well head was composed of a back PVC pipe approximately $10 \mathrm{~cm}$ in diameter that extended downward through the eastern wall profile, below the level of excavation. The presence of modern well head was recorded and mapped. Roughly six meters south of the modern well head, Deposit 2
Table 4-1. Shovel Test Units with Recovered Artifacts.

\begin{tabular}{|c|c|c|c|c|c|c|}
\hline Level & ST 1 & ST4 & ST 6 & ST 7 & ST 8 & ST 9 \\
\hline $\begin{array}{c}1 \\
(0-10 \mathrm{~cm})\end{array}$ & $\begin{array}{l}\text { Plastic = 1 } \\
\text { Metal = }\end{array}$ & Metal=1 & Plastic = & None & None & Plastic = 1 \\
\hline $\begin{array}{c}2 \\
(10-20 \mathrm{~cm})\end{array}$ & Shell =1 & None & None & None & None & Plastic = 1 \\
\hline $\begin{array}{c}3 \\
(20-30 \mathrm{~cm})\end{array}$ & Shell = 10 & None & Metal =1 & Metal = 3 & None & None \\
\hline
\end{tabular}




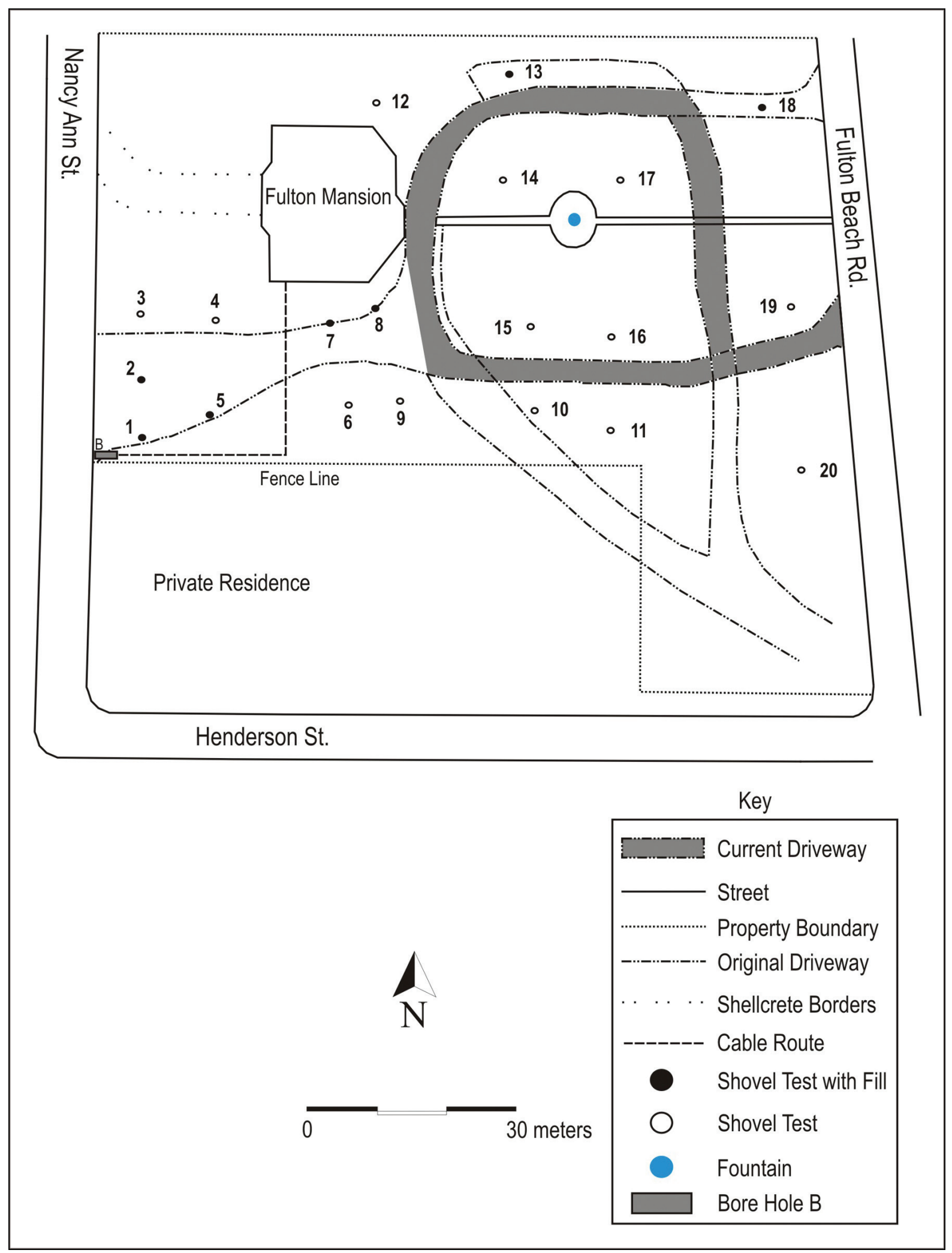

Figure 4-7. Shovel Test location map. 


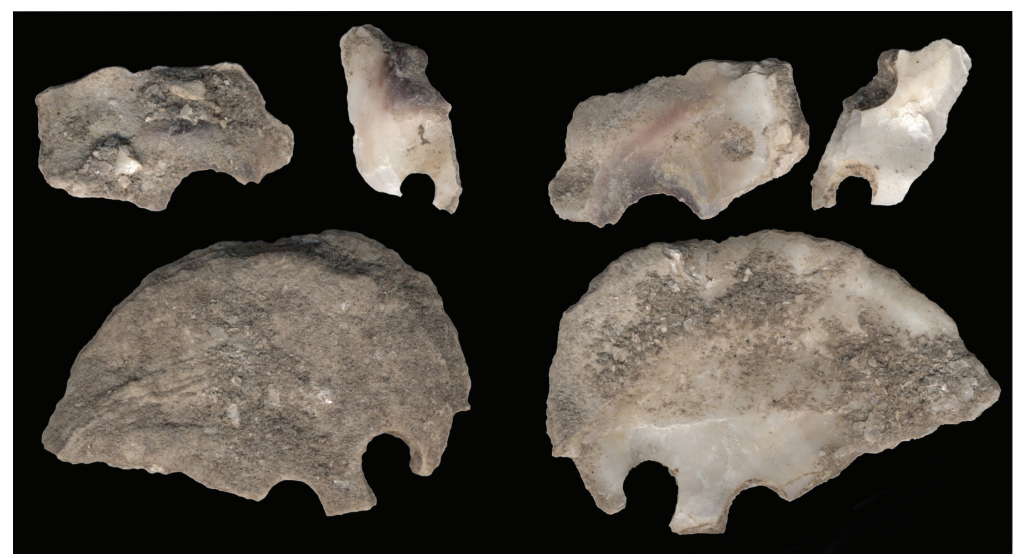

Figure 4-8. Three modified shell fragments; back of shells on left, front on right.

property. These units were excavated in advance of a proposed irrigation system to determine whether a modern fill layer was present within the APE or whether the fill layer was absent and intact archaeological materials were present.

Excavated shovel test units encountered a modern fill layer to the south and southwest of the mansion as well as along the northern boundary of the front lawn (Figure 4-7). These fill locations correspond to an asphalt-and-shell road surface that was uncovered during previous investigations conducted in 1978 (McClenny et al. 1978). A total of 6 shovel test units contained cultural materials (Table 4-1 and Appendix A). Recovered materials consisted of 4 fragments of plastic, 6 fragments of metal, and 11 shell fragments. While the majority of the recovered artifacts were of a modern nature (plastic and metal), three of the shell fragments exhibited drilling marks that might have been of a prehistoric nature (Figure 4-8).

These modified shell fragments were recovered from the bottom of Shovel Test 1 (ST01) at a depth of approximately 31 cmbs and might be indicative of a prehistoric deposit below this depth. Upon close inspection the shell fragments exhibited holes that appear to have been drilled from the interior to the exterior and exhibit a beveled nature. Holes that have resulted from predatory animals would exhibit drill marks extending from the exterior to the interior of the shell. Additionally, what appears as a failed drilling attempt was observed on the interior side of the medium sized shell fragment (see Figure 4-8). These characteristics suggest the holes were the result of human drilling attempts and not the result of drilling by predators such as the southern oyster drill (see Chapter 5 for further discussion). The recovery of a stone projectile point from the flowerbeds near Shovel Test 1 in the 1980s suggests a possible prehistoric presence in this location. However, no similar prehistoric materials were encountered in the surrounding excavated shovel test units. With the exception

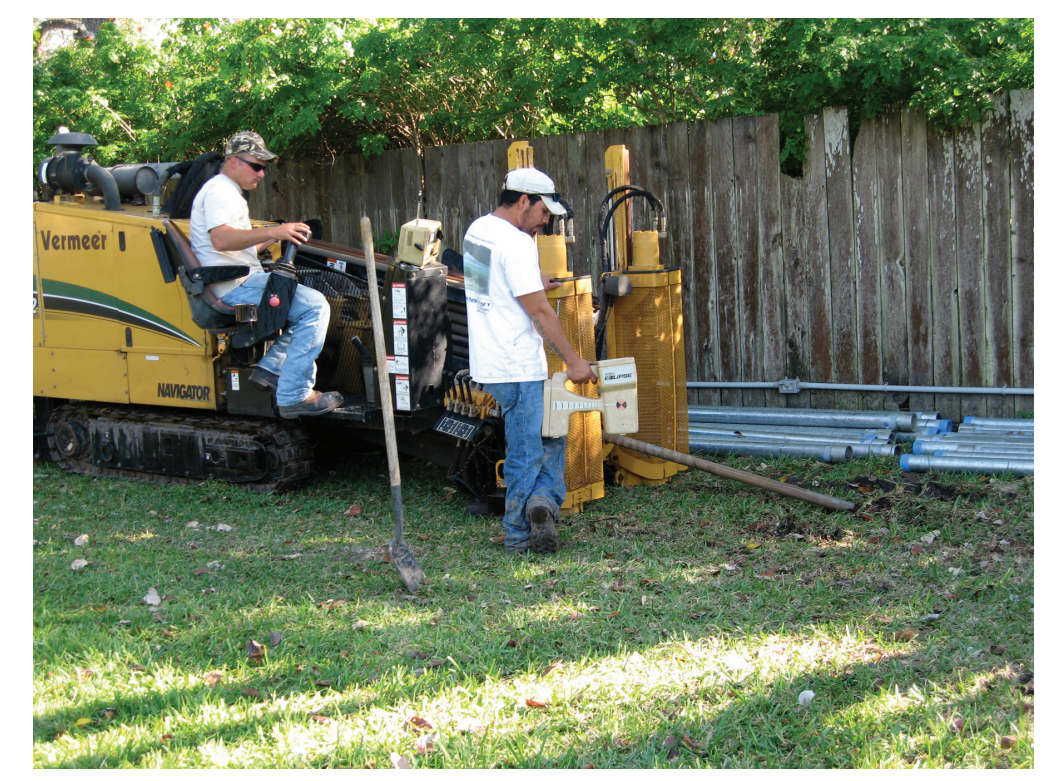

Figure 4-9. Horizontal line boring. 


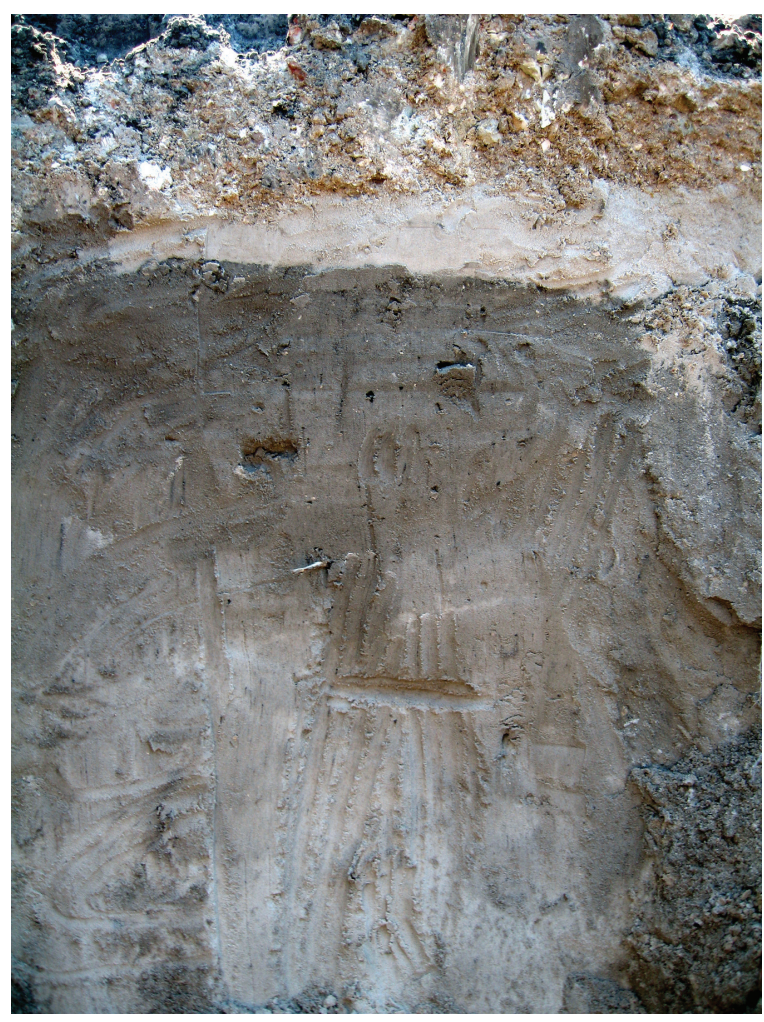

Figure 4-10. Profile picture of Bore Hole A southern wall. Profile measures approximately $90 \mathrm{~cm}$ from top to bottom.

of ST01, and the modern debris recovered from Shovel Test 1, 4, 6, 7, and 8 no features or cultural deposits were encountered during shovel test unit excavations.

\section{Internet Cable Installation Monitoring}

Archaeological monitoring was conducted in advance of the installation of an underground internet cable line consisting of a horizontal boring line and a hand and backhoe-excavated trench. A professional cable installation company excavated a trench by hand and with a Deere 27 backhoe excavator. The cable line trench was approximately 12 inches wide and 24 inches deep, extending from the southwest corner of the Fulton Mansion south to the property boundary, and then west to Nancy Ann Street (see Figure 4-2). Throughout the entire trench excavation small to large roots were documented.

A horizontal bore line was excavated beneath Nancy Ann Street for the installation of the cable line (Figure 4-9). Horizontal boring began to the east of the carport located on the west side of Nancy Ann Street at Bore Hole A. Bore Hole B was excavated on the east side of Nancy Ann Street. Bore Hole A was excavated to an estimated depth of $90 \mathrm{~cm}$. The stratigraphy of the southern wall of the Bore Hole A consisted of a layer of asphalt extending from 0-5 cmbs. At approximately 5 to $15 \mathrm{cmbs}$ a layer of construction fill composed of gravel and sand was encountered. Below the construction fill three layers of sandy loam were recorded (Figure 4-10). From 15 to $23 \mathrm{cmbs}$ a very pale brown sandy loam (10YR 8/2) was documented. Below this, a light brownish gray (10YR 6/2) sandy loam extended from 23 to 54 cmbs. The deepest layer, 54 to $90 \mathrm{cmbs}$, was a very pale brown sandy loam (10YR 8/2). Existing phone, electric, and gas lines were present within

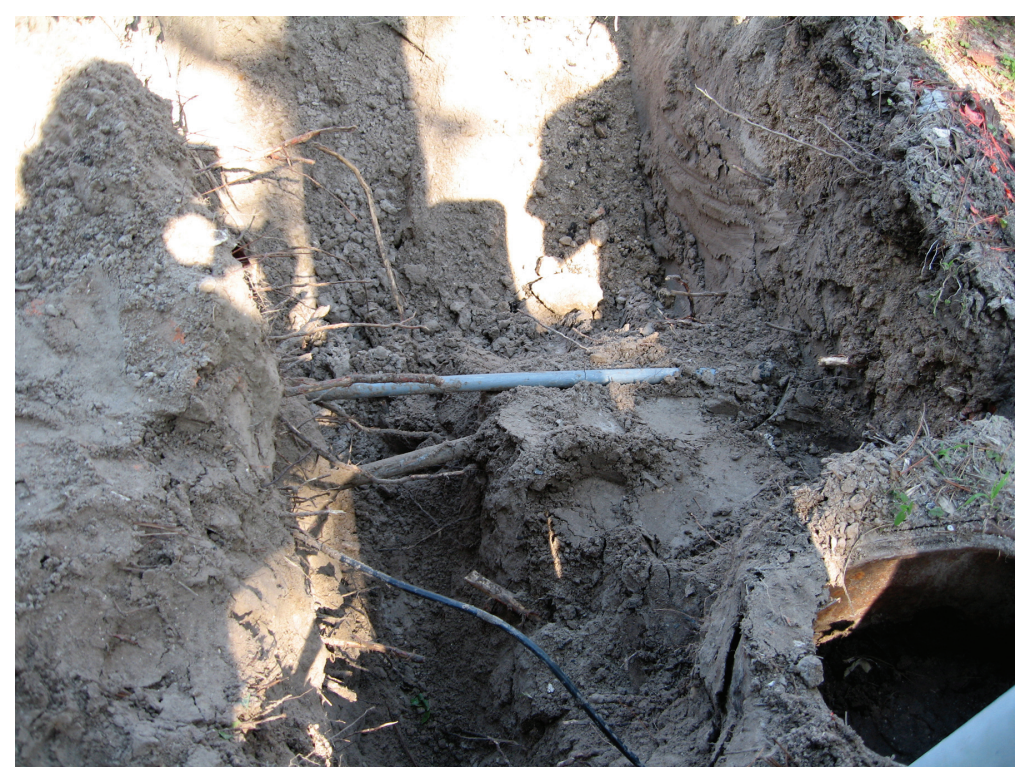

Figure 4-11. Exposed utility lines in Bore Hole A. 


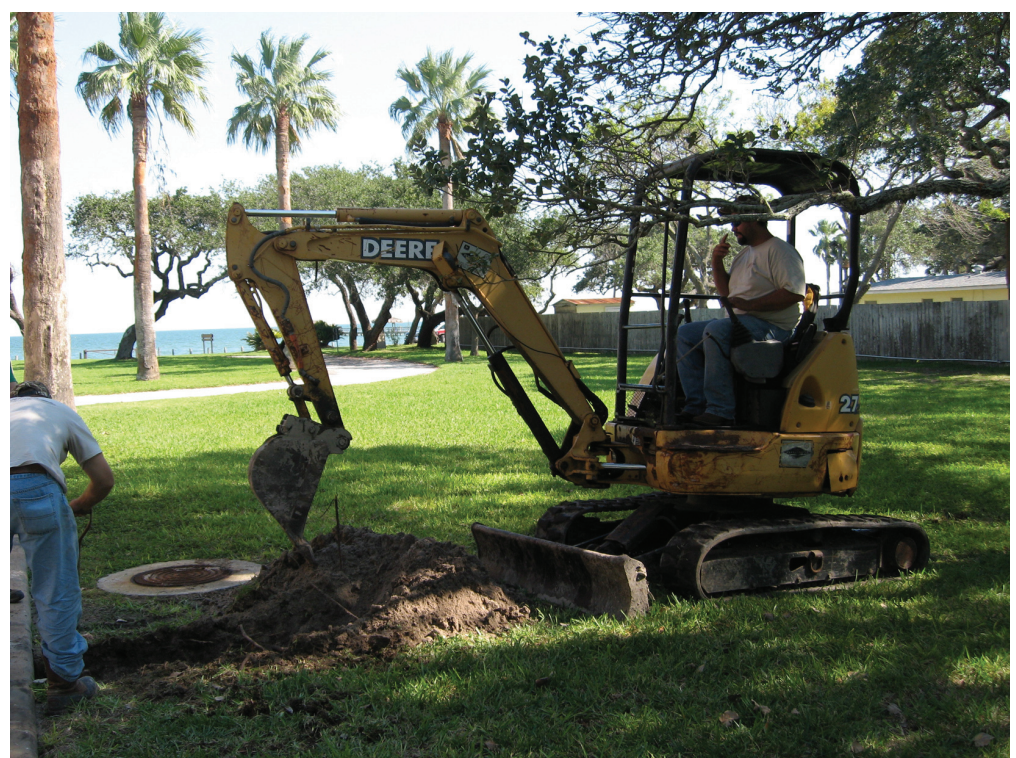

Figure 4-12. Mechanical trench excavation.

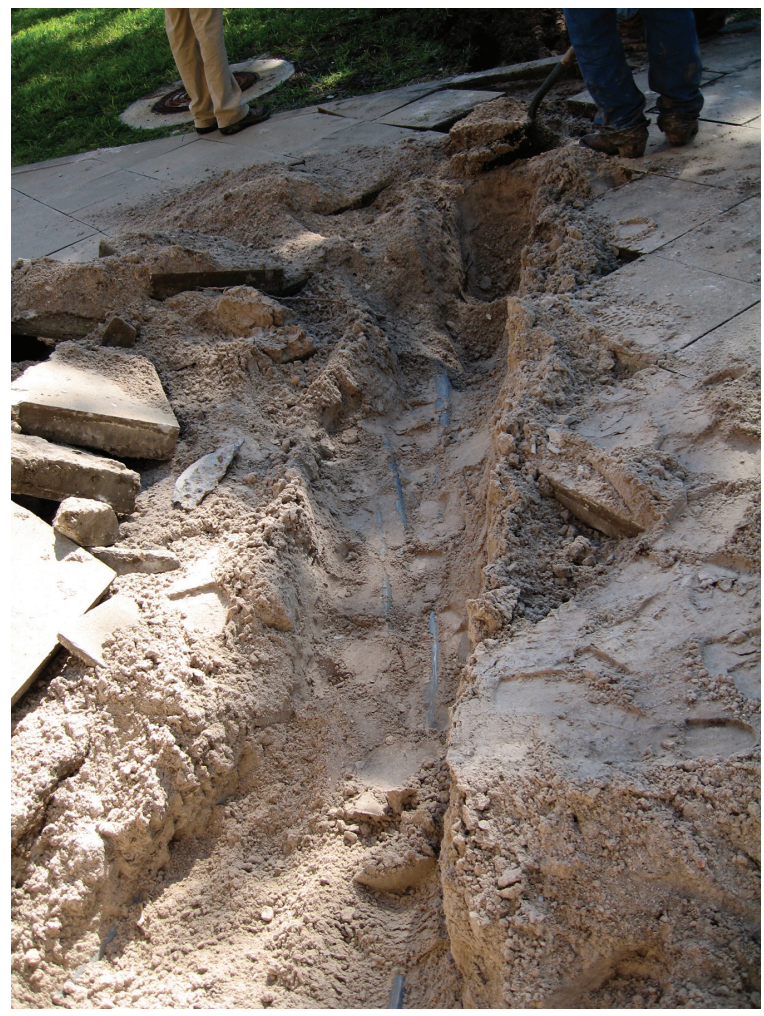

Figure 4-13. Exposed utility lines next to mansion.

the area excavated for Bore Hole A (Figure 4-11) indicating that the area had been previously disturbed. A similar profile was present within Bore Hole B in addition to existing electric lines.
Bore Hole B was also excavated to a depth of $90 \mathrm{cmbs}$.

After the conclusion of the horizontal boring, a Deere 27 excavator equipped with a 12 in wide bucket was employed for the excavation of an open trench (Figure 4-12). Excavations continued by hand in areas of exposed utility lines. The internet cable trench began on the southwest corner of the mansion and extended southward to a pre-existing fence along the southern property boundary. The trench then made a $90^{\circ}$ angle turn toward Nancy Ann Street and terminated at Bore Hole B (see Figure 4-2). A portion of the sidewalk surrounding the exterior of the mansion was removed in order to run the internet cable into the basement. Beneath the square concrete slabs surrounding the mansion, six utility lines were present (Figure 4-13). The trench followed what appeared to be an abandoned waterline running the extent of the trench toward the southern property boundary. Two isolated finds were documented and plotted on the plan map (see Figure 4-2). The first deposit of 10 sea turtle skeletal fragments was identified and recovered from the back-dirt located 13.2 $\mathrm{m}$ from the mansion. The location from which the back-dirt was removed as examined for the exposure of additional bone fragments in the walls and floor of the trench. No additional skeletal remains were noted. The quantity of remains recovered from this deposit is significantly less than that encountered during trench excavations of the proposed parking area. Additionally, the trench extended only to a depth of 24 inches (60 cmbs), far shallower than the depth of previously encountered sea turtle deposit. These facts, in addition to the possibly disturbed nature of the 
Table 4-2. Modern trash deposit.

\begin{tabular}{|c|c|}
\hline Material & Number \\
\hline Bone & 21 \\
\hline Bottle Glass & 11 (7 refit to one bottle) \\
\hline Jar Glass & 24 (4 refit to 2 jars) \\
\hline Glass other - Ashtray? & 3 \\
\hline Other - Paper & 1 \\
\hline Metal & 22 \\
\hline
\end{tabular}

trench locations (following an abandoned water line) led to the conclusion that these remains were not considered to be an intact significant deposits but an isolated find that was separate from the types of refuse turtle deposits encountered during investigations of the parking lot area. The second isolated find consisted of single cow metacarpal. This bone was located $23.8 \mathrm{~m}$ south of the mansion at a depth of $31 \mathrm{cmbs}$. Due to the singular nature of this deposit and the lack of associated features and artifacts, this find was also considered not to be an intact significant deposit.

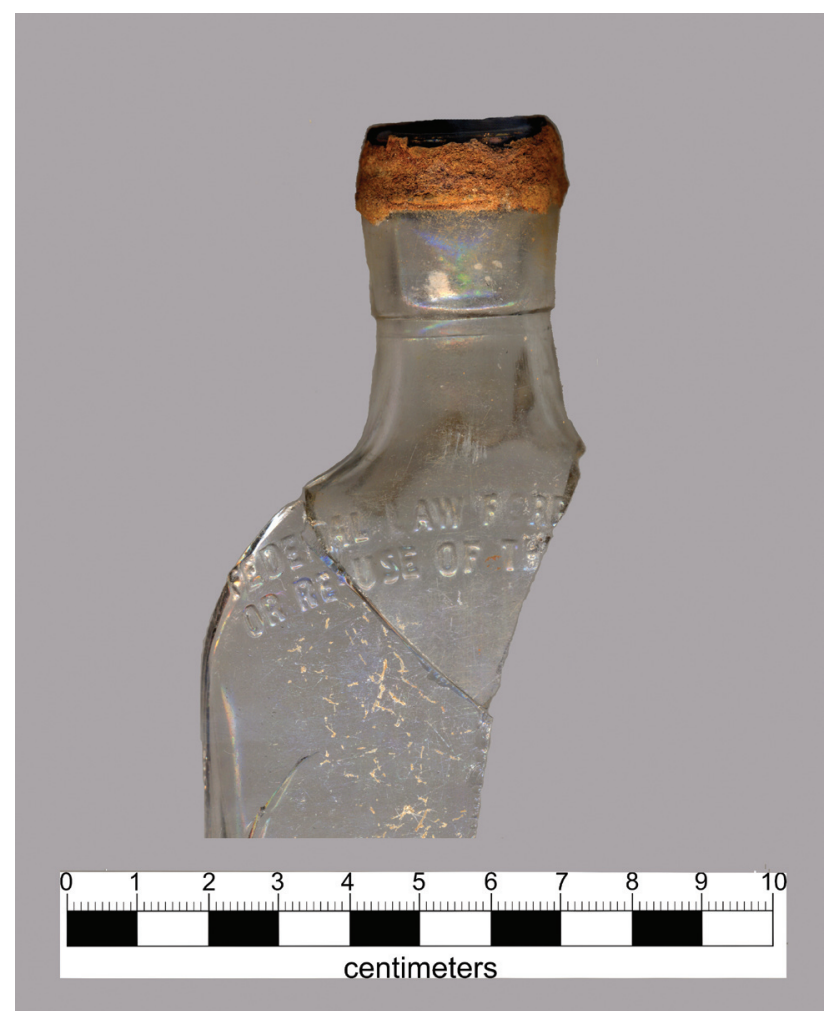

Figure 4-14. Recovered liquor bottle fragment dated to between 1935 and 1964 (refitted).
An approximate 1x1-m by $40 \mathrm{~cm}$ deep deposit of modern trash was uncovered approximately seven m east of Nancy Ann Street during trench excavation immediately adjacent to Bore Hole B. The deposit included glass fragments, bottles, oyster shells, vertebrate remains, and a few metal fragments (Table 4-2). All of the items appeared to have been burned as demonstrated by several burned bones and melted glass fragments. Diagnostic artifacts, including bottles with maker's marks, were collected in order to date the trash deposit. Diagnostic bottle and jar fragments included colorless bottle and jar fragments with a Knox Glass Bottle Company maker's mark, manufactured in Jackson, Mississippi from 1932 to 1953 or later; colorless liquor bottle fragments (refitted) with a Diamond Glass Company maker's mark, manufactured in Royersford, Pennsylvania embossed with FEDERAL LAW FORBIDS SALE OR RE-USE OF THIS BOTTLE dating the bottle between 1935 and 1964 (Figure 4-14); a colorless 5-quart jar fragment with a Hazel-Atlas Glass Company maker's mark, manufactured in Wheeling, West Virginia, between 1920 and 1964; and two amber beer bottles manufactured by the Owens Illinois Glass Company in Toledo, Ohio sometime after 1954. Based on the dates of manufacture of these diagnostic glass bottle and jar fragments, the deposit appears to be a modern trash deposit that may be associated with a recent trailer park once present on the 
Fulton Mansion property in the 1960s and 1970s. Analysis of bone and oyster shell recovered is presented in Chapter 5.
The presence of the pre-existing water and utility lines within the excavated trench indicate that the area had been previously disturbed. No intact potentially significant prehistoric or historic deposits were impacted by the horizontal boring and trench excavations. 


\section{Chapter 5}

\section{FAuna}

Cinda Timperley

\section{Introduction}

In the mid to late 1800 s turtle fishing was a lucrative and widespread activity along the Texas Gulf coast, as in Victorian society it was fashionable to eat turtle soup. Beef packing plants were converted to turtle canneries in order to ship soup and meat across the country, and individual households with access to the Gulf coast also partook of this marine delicacy. The Fulton household was no exception as attested to by the skeletal remains of several green sea turtles (Cheloniidae: Chelonia mydas) that were recovered during archaeological testing of the Fulton Mansion State Historical Site proposed Visitor's Center grounds.

Excavation efforts recovered 8526 elements or fragments of bone, tooth, and invertebrate remains in the course of the 2009 investigation of the proposed Visitor's Center. This amounts to $27.50 \mathrm{~kg}(59.84 \mathrm{lb})$ of faunal remains. A breakdown by lot and taxonomic group appears in Appendix B. Sea turtle (Family Cheloniidae) remains comprise the majority of material at 95 percent by count and 93 percent by mass. Mammal, fish, and invertebrates make up the balance of the assemblage. Material examined here was recovered from EBHT Test Unit 1, EBHT Test Unit 2, Bore Hole B, and Trench Monitoring (Figure 4-2).

Preservation of the bone ranges from nearpristine (no appreciable alteration) to severely degraded. A limited range of elements exhibit cut marks from butchering, while a large variety of others show signs of having been scavenged. There are also flat-bottomed grooves left by rodent incisors on some specimens. The scalloped edges and puncture marks on other specimens suggest that a scavenger the size of a dog or coyote was also utilizing this marine resource.

\section{Methods}

Faunal material was hand excavated as it was encountered in the field except that which was unearthed by the backhoe. Despite being buried in a sandy matrix, very little permineralization has occurred in the bone. However, the water table is known to rise and fall dramatically in this area, and this process tends to leach material from bone (Collins 2002, Ringstaff 2008, Timperley et al. 2003). Therefore, it is fragile, but most specimens withstand careful handling. Several specimens comprise weakly cemented stacks of what appear to be sea turtle carapace fragments. It is unclear whether these initially were complete or nearly complete carapaces stacked after butchering, as the specimens were so fragmentary as to preclude attempts at mending. The carapace bone in these stacks is highly friable and difficult to safely manipulate for most purposes of analysis. No specimen was removed with plaster field jacket, and due to the small size of collection bags on hand, the majority of the faunal material was 
packaged in 5-gallon plastic buckets. This rigidwalled packaging provided a considerable degree of protection to the fragile bone.

Once the faunal material was brought in to the CAS laboratory it was spread on newspaper in drying trays. Some material was allowed to dry in the buckets prior to being placed in the drying trays. This allowed the bone to dry slightly prior to further handling. Dry bone is more stable and maintains its integrity better than wet bone during handling. After several days, the material was checked for stability during handling. When the bone was suitably dry, adhering matrix was gently brushed away with a natural bristle paint brush and/or a nylon bristle tooth brush. This matrix was retained and screened with a metal food strainer of ca. 1/8" mesh.

The faunal material was then packaged by lot number and tagged with preliminary identifications: mammal bone, sea turtle shell, sea turtle bone, etc. A more detailed analysis was conducted one lot at a time, with the aid of a 10x hand lens, a magnifying lamp, and a binocular light microscope.

Specimens were identified as specifically as possible to taxon and element, and carefully examined for traces of butchering or other anthropogenic modification. Other taphonomic signatures were noted as well. Analysis proceeded with identification to species where possible. Several resources were heavily employed in the task of species identification and element siding, including Frick (1996), Valente et al. (2007), Wyneken (2001), Zangerl and Sloan (1960), a variety of websites (e.g., Peterson 2010, Everhart 2009), and comparative material held in the Recent Osteolgy Collection in the Vertebrate Paleontology Laboratory of the Texas Natural Science Center, The University of Texas at Austin.

\section{Taxonomic Descriptions}

Invertebrate classification follows Boardman et al. (1987) and Andrews (1971). Vertebrate systematics follows Pecor (2003) for sea turtles and Dewey (2001) for mammals. Bovid postcranial skeletal identifications follow Todd (2001). Abbreviations: TMM M $=$ Texas Memorial Museum Recent Osteology Collection specimen; $\mathrm{MNI}=$ minimum number of individuals; NISP = number of individual specimens; $\mathrm{n}=$ count; $\mathrm{g}=$ grams; $\mathrm{kg}=$ kilograms; $\mathrm{lb}=$ pounds.

\section{SYSTEMATICS}

Kingdom Animalia

Phylum Cnidaria

Class, Order, Family, Genus et species indet.

Lot 4 (Appendix C)

One small fragment of Cnidaria (coral) was recovered in Lot 4 . This specimen is rounded and considered here part of the ground mass of the site's beach sand matrix.

\section{Phylum Arthropoda}

Superclass Crustacea

Class Malacostraca

Order Decapoda

Family, Genus et species indet.

\section{Lot 24 (Appendix C)}

Two small claws assignable to Order Decapoda (lobsters, crayfish, shrimp, and crabs) were recovered in Bore Hole B. 
Phylum Mollusca

Class Bivalvia

Order, Genus et species indet.

Lots $1,2,5,6,7,10,11,12,14,24$

\section{(Appendix C)}

Small fragments of what appear to be rounded oyster shell occur in the assemblage, most likely as part of the ground mass of the site's beach sand matrix. Other specimens appear to be bivalve shells that have been anthropogenically altered (see chapter 4 for further discussion). One of the primary predators of Crassostrea virginica (American oyster) is Stramonita (=Thais) haemastoma, the southern oyster drill, a gastropod widespread along the Gulf Coast and up the Eastern Seaboard (Stanley and Sellers 1986; Watanabe and Young 2006). This gastropod often does not drill through the oyster shell, but rasps a gap between the valves and inserting its proboscis into the mantle cavity to feed (Stanley and Sellers 1986). Butler reports that young Stramonita (=Thais) drill holes 0.1 to $0.2 \mathrm{~mm}$ diameter, with the diameter increasing to 1 to $2 \mathrm{~mm}$ by adults (Butler 1985). The diameters stated here are far smaller than those observed on the archaeological specimens under discussion which further supports the contention that the holes are the result of human alteration.

Phylum Chordata

Class Osteichthys

Order, Family, Genus et species indet.

Lots 1 and 2 (Appendix C)
Two fish elements were recovered, a small vertebra and a small skull bone. Both specimens could be grains from the beach sand ground mass or could have come from kitchen rubbish.

\section{Class Saurposida}

Order Testudines

Family Dermochelyidae

cf. Dermochelys coriacea

$$
\text { Lot } 4 \text { (Appendix C) }
$$

One ilium in two fragments is assigned to this taxon. This specimen has been provisionally assigned to $D$. coriacea due to its overall morphology. The articular surfaces that contact the pubis and ischium are highly rugose. This is characteristic of leatherback turtles. The pelvic girdle does not ossify completely, maintaining both cartilage and bone throughout life (Wyneken 2001). It exhibits cut marks suggesting butchering.

Family Cheloniidae

Genus et species indet.

Lots $1,2,4,5,6,7,8,9,10,11,12$

(Appendix C)

Hundreds of isolated fragments are classified here. These are largely carapace or plastron fragments that do not readily mend with other fragments. Some skull material and rib fragments also have been assigned to this category.

The vast majority of faunal maerial recovered during the current phase of testing at the Fulton Mansion State Historical Site proposed 


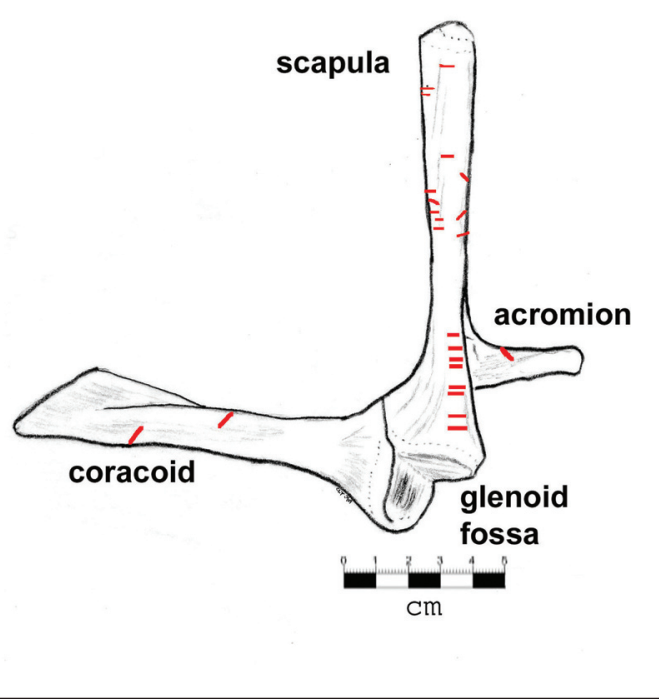

Figure 5-1. Right pectoral element of Chelonia mydas (green sea turtle, TMM M-6567) in lateral view. Composite illustration of locations of observed cut marks. The scapula points dorsally, the acromion process medially, and the coracoid medio-ventrally.

Visitor's Center grounds is classifiable to family Cheloniidae, sea turtle.

\section{cf. Chelonia mydas}

Lots 2, 3, 6, 7, 10, 11, 12, 23 (Appendix C)

Specimens are provisionally assigned to this taxon if some diagnostic character is missing from the element, the specimen is too degraded for confident identification, or some individual variation exists to cause some doubt in identification. This includes several skull, pectoral, pelvic, limb, and shell elements and fragments.

\section{Chelonia mydas}

\section{Lots 5, 6, 7, 10, 11(Appendix C)}

Several identifiable cranial and postcranial elements can be assigned to this taxon. Skull material is assignable to Chelonia mydas based on comparisons with Recent material and morphological characteristics outlined by Feuer (1970) and Wyneken (2001). At least eight individuals, based on the minimum number of right humeri, are represented in the Fulton Mansion 2009 assemblage. The 2007 assemblage adds a minimum of three more individuals, bringing the total MNI to 11. Ringstaff obtained a MNI of seven based on number of coracoids present in the 2007 assemblage (Ringstaff 2008: Appendix 2).

A minimum of eight individual green sea turtles is represented by right humeri from Lot 6 . Other elements are present as well. Lot 6 yielded more than $10 \mathrm{~kg}$ of turtle bone: $5.4 \mathrm{~kg}$ of shell plus $4.3 \mathrm{~kg}$ non-shell postcranials and $0.9 \mathrm{~kg}$ indeterminate turtle material (Appendix B). One specimen, a hypoplastron fragment from Lot 7, may be assignable to either $C$. mydas or Caretta caretta, loggerhead turtle. It is not well preserved enough for confident assignment.

Preservation varies from poor to wellpreserved. The poorly preserved material was best represented by cemented carapace/plastron material from Lot 6 . These fragments appear to

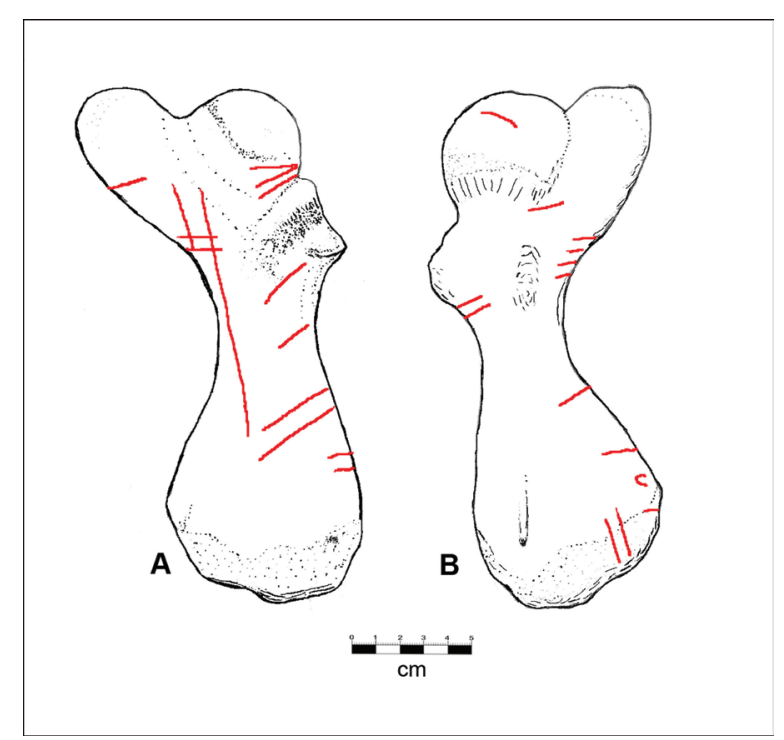

Figure 5-2. Left humerus of Chelonia mydas (green sea turtle) in A: ventral, B: dorsal view. Composite illustration of locations of observed cut marks. 


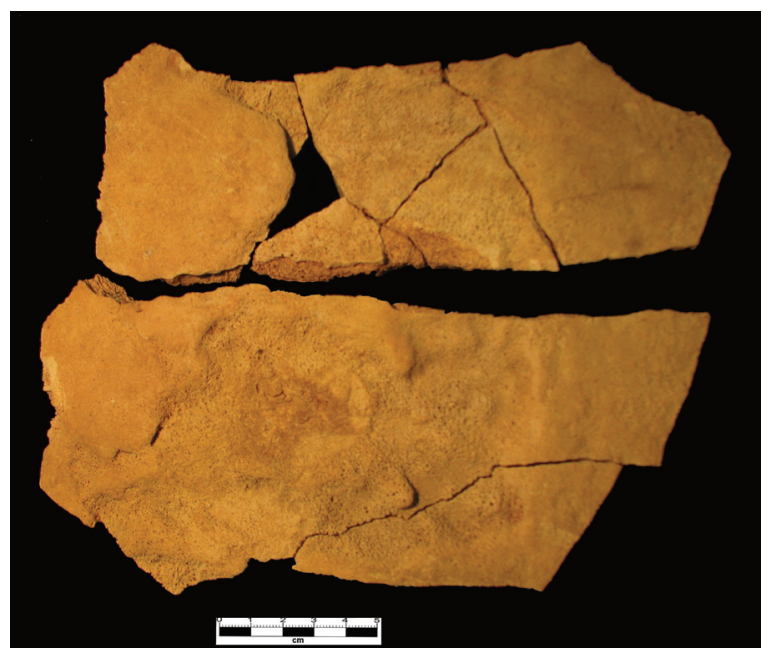

Figure 5-3. Pleural fragments of Chelonia mydas (green sea turtle) exhibiting lumpy remodeled exterior bone indicative of healed infection.

have been carapaces that had been stacked up in a pile prior to burial. Up to five stacked shell fragments were identified in one mass. These bone masses are extremely fragile and would benefit from treatment by a consolidant. Material with the best preservation, that is, specimens that look freshly deposited, were also recovered in Lot 6.

\section{Class Mammalia}

Order, Family, Genus et species indet.

Lots 2, 6, 7, 10, 12, 24 (Appendix C)

Material unidentifiable beyond class level was recovered in several lots.

\section{Order Artiodactyla \\ Family Bovidae \\ Bos cf. Bos taurus}

Lot 1, 2, 6, 22, 24 (Appendix C)
Domestic cattle are represented by several identifiable elements. One tooth fragment and eight bone fragments were recovered from the test units, and robust, identifiable elements were recovered from Bore Hole B. These elements are from at least one young individual, a calf.

\section{Taphonomy}

\section{Butcher marks}

Butcher marks were observed on pectoral elements, humeri, and pelvic elements (Figures 5-1, 5-2). The cut marks occur in the same positions on the 2009 specimens as on the 2007 specimens.

\section{Pathology}

The faunal assemblage includes a few elements exhibit some pathology. A radius from Lot 7 has an osteologically remodeled proximal end. Several carapace fragments exhibit lumpy and irregular but smooth remodeling of the dorsal/ exterior surface (Figure 5-3). The remodeling of pleural bone seen on several specimens is likely due to some type of shell infection. The exact nature of infection is unclear, and it is unknown

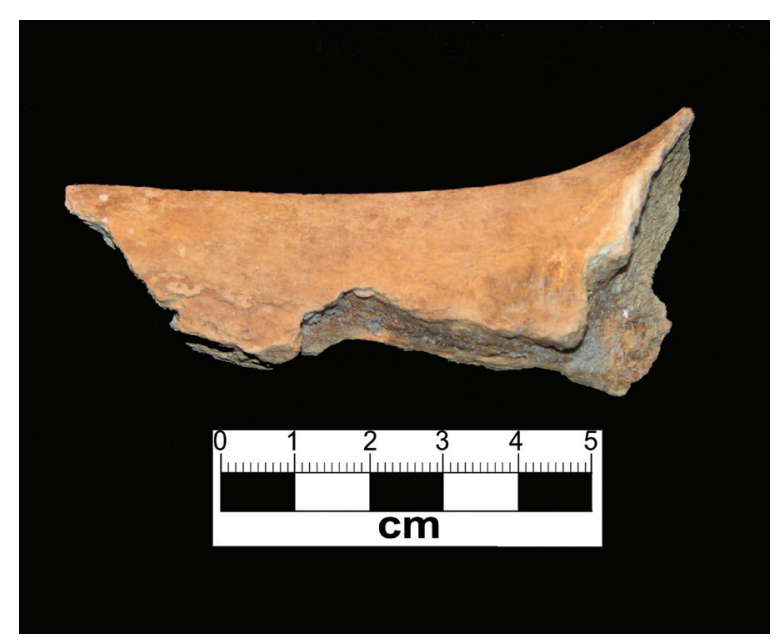

Figure 5-4. Cheloniidae bone fragment with scalloped edges typical of carnivore activity. 
whether the individual(s) involved had been held in pens prior to butchering. Doughty (1984) reports that "crawls", or holding pens, were constructed in roughly $2 \mathrm{~m}$ deep water using wooden stakes or poles driven into the substrate. These pens were 100 to $500 \mathrm{ft}^{2}$ in area, and held the live turtles until ready for butchering or shipping. There is no evidence in the Fulton Mansion SHS artifact assemblage to support or refute that the Fulton household had its own "crawl". The pen would not be on the mansion grounds immediate to the house, but down at the beach.

\section{Scavenging}

Numerous examples of scavenging occur throughout the 2009 assemblage, marked by puncture marks about a centimeter in diameter and scalloped edges on long bone diaphyses and margins of flat bones (Figure 5-4).

\section{Summary}

A total of 8542 invertebrate and vertebrate faunal elements were recovered during the 2009 excavation. This total includes 41 oyster shell fragments, 8107 sea turtle shell and nonshell elements and fragments, 48 mammal bone fragments, and 3 mammal tooth fragments.

\section{Invertebrates}

The invertebrate material is mostly represented by small, smooth fragments, and these appear to be incorporated into the beach deposit matrix, including fragments of clam and oyster shell, coral, and crustacean. Invertebrates also are represented by nine pieces recovered from Bore Hole B and three modified oyster shell fragments that were found in Shovel Test 1 (Figure 4-8).

\section{Bone}

Of the total 8526 bones/bone fragments recovered during this investigation, the highest amount was recovered in Lot 6 , followed by significant amounts in Lots 7, 12, and 11 (Appendix B). Material from Lot 6 largely consisted of sea turtle (Cheloniidae) with a small percentage of that identifiable to Chelonia mydas (green sea turtle). The total mass of cheloniid material recovered equals $25.1 \mathrm{~kg}(55.3 \mathrm{lb})$. Bovid material comprises 0.4 percent of the faunal assemblage. This subassemblage consists of bone fragments with thick cortex, two tooth fragments, and several limb elements from a young individual, all assignable or tentatively assigned to Bos taurus.

Contrasted with Ringstaff's (2008) results of sea turtle comprising 79 percent of the recovered faunal material, sea turtle comprises 95 percent by count and 93 percent by mass of the 2009 faunal assemblage. His taxonomic identifications were based on the most diagnostic element in a sea turtle skeleton, the entoplastron. While his investigation recovered two entoplastra, this investigation recovered none. Species diagnosis was made based on the combination of cranial material, neural carapace bones, pleural carapace bones, pectoral elements, and humeri. These identified elements were assignable to Chelonia mydas (green sea turtle). Given that specimen 12-1, a portion of carapace, was identified as $C$. mydas, it is reasonable to presume that most, if not all, the remaining carapace and plastron material as well as non-shell postcranials in all lots can also be assigned to C. mydas. Skull bones from lots 7, 10, and 11 are also assignable to $C$. mydas. 
Minimum number of individuals derived from a survey of the 2009 assemblage equals 8 based on counts of both the left and right humeri (Appendix C). There may be as many as 13 individuals represented, based on right humeri. However, the four fragments that supplement the MNI are possible mends to some of the humeral shafts that comprise the MNI specimens. Skull elements in Lot 11 articulate to one skull. Left and right prefrontals and the basioccipital are duplicated once, making MNI equal to two based on skull material.

Cut marks and scavenging marks were observed on several specimens. A preliminary examination using a 10x hand lens and strong lighting revealed such damage on several specimens. Further examination using a binocular light microscope of $10 x$ to $30 x$ power confirmed this. The elements affected and locations of the cut marks are consistent with butchering, as observed by Ringstaff (2008). However, while he observed cuts on plastron elements, none were found on those elements in this assemblage. Cuts were primarily found on pectoral elements, but also on humeri (see Figures 5-1, 5-2). Gnaw marks by rodents and scalloping and puncture marks by larger carnivores such as dogs were also observed (see Figure 5-4).

\section{Turtle Industry}

It is reported that the first canning of Chelonia mydas occurred at beef packing plants on Aransas Bay in 1869, with production moving to a small factory in Fulton 10 years later (Bowers 1899). At the start of the $1880 \mathrm{~s}$, turtles were a minor component of the overall catch at 16 percent by mass, 10.5 percent by monetary value (Doughty 1984). Commercial fishing in the Texas Gulf Coast region accelerated in the $1880 \mathrm{~s}$, and the take included various invertebrates, fishes, and turtles (Doughty 1984). Turtle meat and turtle soup canning had been conducted in the area since the late 1860 s but some packing plants had folded before the upswing in popularity of turtle soup in the 1880s (Doughty 1984). As the beef packing and processing industry declined toward the late 1870 s, many of the plants supplemented or even replaced business with turtle packing.

As this industry progressed, Aransas Bay became an important location in procuring sea turtles, and a turtle cannery was established there in 1881 (Doughty 1984). Goode (1887) reported that a canning company that "has been in existence only about one year" canned about 8,500 pounds of meat in the first six months of operation (Goode 1887:498).

In the 1890 s turtles were an important part of the sea catch but depletion became evident by 1892 (Doughty 1984). The green sea turtle, Chelonia mydas, was the primary species caught and utilized in the turtle canning industry. The Fulton cannery operated until 1896. Annually, it processed approximately 1,000 turtles, each weighing on average $250 \mathrm{lb}$ (Bowers 1899). In the late 1890 s, turtle hunting declined. Doughty (1984) suggests that local activity moved south due to the closing of Fulton Cannery, as the effects of overhunting were probably also impacting the local market. Canneries closed and sea turtle was either harvested for local consumption or shipped live and trussed to other markets on a small scale (Doughty 1984). Despite the decline at the commercial level, turtles were, and are still taken for small-scale consumption. Recipes abound from that time period for turtle soup for the wealthy, and the middle class made mock turtle soup using veal as a base. Recipes are readily available for both on internet websites and in contemporary and Victorian-era cookbooks (e.g., Alinat 2005, Byrne and Duggan 1970: 397; Hunter, Rose and Co. 1877: 58). Today the turtles are farm-raised, including snapping turtle and soft-shell turtle (Alinat 2005). 
Walraven (1985) summarized turtle harvesting in the Rockport area from anecdotal reports, noting the presence of canners at Fulton, North Beach, and other communities. He also notes the decline of turtle hunting in 1900. On February 13, 1900 the temperature dropped so low that "birds dropped into the bay dead" and that in places ice was thick enough "to hold six men" (Walraven 1985). Since turtles are reptiles and therefore cold-blooded, this temperature range subjects them to cold-stun, allowing easy capture.

\section{Endangered status of sea turtles}

Severe decline in Texas sea turtle populations was recognized in the early 1890 s, and exacerbated in the 1900 freeze. Population numbers did not recover. Conservation regulations were first implemented in the mid to late 1890 s, limiting the season for egg collecting, restricting the size of animals taken to greater than $12 \mathrm{lb}$, and requiring a license (Doughty 1984).

Seven species of sea turtle in two genera are in existence today. Six of these are found in U.S. waters: Dermochelyidae: Dermochelys coriacea (leatherback sea turtle), Cheloniidae: Caretta caretta (loggerhead), Chelonia mydas (green), Lepidochelys kempi (Kemp's ridley), Lepidochelys olivacea (olive ridley), and Eretmochelys imbricata (hawksbill). The seventh species, Cheloniidae: Natator depressus (flatback) is found in the waters around Australia. All sea turtles are considered endangered under international conservation codes.

The National Oceanic and Atmospheric Administration website (http://www.nmfs.noaa. gov/pr/species/turtles/) lists threats to all species of sea turtle including reduction and modification of nesting grounds, light pollution, illegal fishing, by-catch in fishing nets and on fishing lines, marine debris, injury from boat propellers, habitat contamination, and diseases.

Some correlation can be drawn between the increased intensity and hunting pressure on the sea turtles and their population declines. Ethnographic accounts record anecdotal evidence that people would follow female turtles to nesting grounds and harvest freshly-deposited eggs. Apparently the egg clutch stripped from the female prior to deposition was more desirable, especially in the case of loggerheads (Doughty 1984). At the height of demand, no regulation existed to mitigate the removal of reproductively viable individuals in the numbers that were being harvested, nor any thought given to the nurturing of offspring, including eggs, to maintain the resource.

\section{Conclusion}

It appears that the faunal material, except for the small mollusk fragments and modified oyster shell fragments, is derived from household rubbish piles/pits. Ringstaff (2008) suggested that the turtle remains found in 2007 had been deposited in pits. That is likely with the 2009 remains as well. They occur in more or less discrete groupings. While there is no evidence in the profiles of pit margins, the bones were contained as a group by some confining factor. These deposits are within ca. $60 \mathrm{~m}$ (200 feet) of the back door of the house. The distribution and small scale processing evident by the number of remains supports the hypothesis that these faunal remains are the result of dumping and sometimes burying kitchen rubbish in the grove of trees behind the house. 


\section{Chapter 6}

\section{Summary ANd Recommendations}

Carole Leezer

The Center for Archaeological Studies (CAS) at Texas State University-San Marcos conducted additional archaeological investigations for the proposed Fulton Mansion State Historic Site Visitor's Center, Aransas County, Texas between October 19, 2009 and November 13, 2009. The THC intends to enhance the Fulton Mansion State Historic Site by constructing a visitor's center and parking area to be located west of the Fulton Mansion. A testing project for the Fulton Mansion Visitor's Center was conducted by the Texas Parks and Wildlife Department (TPWD) in 2007 while the site was under TPWD management (Ringstaff 2008). Since then, the site has come under the management of the Texas Historical Commission and the area of potential effect (APE) of the visitor's center has doubled to accommodate an enlarged parking area. The current project was conducted as an addendum to the previous investigations conducted by Ringstaff in 2007 (2008) and examined the new, previously untested area, while also addressing some recommendations from the earlier project.

Following the completion of Ringstaff's (2008) report, it was determined in consultation with TxDOT and the SHPO (May 26, 2009, Memo on Proposed Additional Work at the Fulton Mansion Visitor's Center, Aransas County) that additional investigative work was needed. CAS conducted an investigation of the APE as a continuation of testing investigations begun by Ringstaff in 2007 to advise in the final determination of NRHP eligibility. Investigations consisted of the excavation of backhoe trenches within the proposed visitor's center parking lot and in the location of a proposed electric utility line construction, in addition to providing archaeological monitoring of a cable internet line installation between the proposed visitor's center and the mansion. The project scope was expanded to also include shovel test investigations in advance of an irrigation system installation on the front and side lawn of the mansion property.

It was believed that the construction of the electric utility line may impact cultural deposits identified by Ringstaff (2008) as it is proposed to be placed approximately three inches above the level of the previously identified deposits. In order to explore the potential for this occurrence a backhoe trench, UBHT, was excavated in the area of the proposed electrical line. No cultural deposits were encountered in the area trenched and it is believed that area of the proposed electrical line location consists of disturbed soils due to the presence of water utility lines. CAS contends that no cultural resources will be impacted by the proposed placement of the electric utility line.

The primary scope of work was expanded to include the excavation of 20 shovel test units in advance of a proposed irrigation system installation. The irrigation system project is not part of the statewide Transportation Enhancement Program funding and is not under TxDOT's purview. Shovel test units were excavated in order to determine whether or not (1) the modern 
fill layer identified by Ringstaff (2008) within the footprint of the proposed Visitor's Center extended to and was present in the APE of the proposed irrigation lines or (2) whether the fill layer was absent and intact archaeological materials were present. Shovel test units excavated to the south and southwest of the mansion as well as along the northern boundary of the front lawn area encountered a modern fill layer. These locations correspond to an asphalt-and-shell road surface that was uncovered during previous investigations conducted in 1978 (McClenny et al. 1978). One shovel test unit, ST01, uncovered modified prehistoric shell at a depth of $31 \mathrm{cmbs}$ in the far southwest corner of the mansion property. These materials may be indicative of a prehistoric deposit below this depth, as no similar prehistoric materials were encountered in the surrounding excavated shovel test units. A stone projectile point was recovered from the flowerbeds near the location of ST01 in the 1980s suggesting a prehistoric presence within the project area. The point is currently housed at the TPWD Archeology Lab (Ringstaff 2008). CAS recommends that this area be avoided during the installation of the irrigation system. In a letter from Mark Denton to Scott Pletka dated March 24,2010 , the THC agrees to avoid this area of the site and that the irrigation system project will be installed only in the areas where no prehistoric cultural materials were recovered during the shovel test excavations.

Archaeological monitoring was conducted in advance of the installation of an underground internet cable line that consisted of horizontal boring and a hand and backhoe-excavated trench. The cable line trench was excavated by a professional installation company: it was approximately 12 inches wide and 24 inches deep and extended from the southwest corner of the Fulton Mansion south to the property boundary, and then west to Nancy Ann Street.
A horizontal bore line was also excavated beneath Nancy Ann Street for the installation of the cable line. Trenching revealed numerous utility lines next to the mansion in addition to an abandoned water line and two isolate deposits. Isolated deposits consisted of a deposit of 10 sea turtle fauna fragments and a single cow bone. Due to the nature (depth and amount) of the sea turtle deposit it was not considered similar to the types of deposits encountered during previous investigations or during current investigations of the parking lot area. A trash deposit of recent modern trash was also encountered adjacent to Bore Hole B. CAS contends that the cable installation line area is composed of disturbed sediments due to the presence of numerous utility lines and the likelihood that intact, significant cultural deposits would be impacted by the cable installation is low.

The primary objective of the current investigations was to determine if similar deposits identified by Ringstaff (2008) during the investigation of the visitor's center building APE are also located within the APE of the visitor's center parking lot. Cultural deposits were identified during Ringstaff's archeological testing project at approximately 35.4 in $(90 \mathrm{~cm})$ below the surface. These deposits consisted of animal carcass refuse disposal primarily containing disarticulated Chelonia mydas (green sea turtle). Ringstaff (2008) concluded that the encountered disarticulated sea turtle bone deposits constituted a contributing element to the NRHP listed Fulton Mansion under Criteria D (36 CFR 60.4). In addition, the ground disturbing activities associated with the construction of the visitor's center constituted an adverse effect (36 CFR $800.5)$ to this contributing element (Ringstaff 2008). To mitigate the adverse effects to these cultural deposits associated with the construction of the visitor's center, architectural plans were drafted that called for 30 in $(76.2 \mathrm{~cm})$ of fill to be 
utilized as a pad upon which the building will sit. As such, features within the APE will be avoided as the deepest building foundation beam will be 11.4 in $(29 \mathrm{~cm})$ below the current existing grade.

During the current investigations of the visitor's center parking lot area, cultural deposits similar to those identified by the previous investigations were encountered at 50 to 80 cmbs. Three deposits consisting primarily of disarticulated Chelonia mydas (green sea turtle) were identified during backhoe trench excavation of the parking lot area. The location of these deposits, behind the mansion, is regarded as possessing a high probability of direct association with the George W. Fulton family occupation of the Fulton Mansion. The mansion property originally consisted of 60 acres, including the area of the proposed expanded parking lot. While there is no record of the Fultons' use of turtle meat or where it was acquired, turtle soup was a popular dish during the Victorian Era. Turtle soup was also a product of the regional turtle fishery industry in the late 1800s. A turtle cannery, the Fulton Canning Company, was established in Fulton by beef packers in 1881. By 1890 the cannery processed 900 green sea turtles weighing a total of $110,455 \mathrm{~kg}$ (Reeves and Leatherwood 1983; Stevenson 1893). This cannery produced 40,000, $32 \mathrm{oz}$ cans of turtle meat and 3,600, 32 oz cans of turtle soup in 1890 (Reeves and Leatherwood 1983).

The rise and fall of the local turtle fishery (circa 1870-1900) is documented by Doughty (1984), who describes a cannery (most likely the Fulton Canning Company) and turtle pens located along Aransas Bay in Fulton in 1881, approximately one half mile north of the mansion. Green sea turtles (Chelonia mydas) were the primary species caught and accounts detail the butchering of the turtles on the pier next to their pens (Doughty 1984). While the deposits encountered were not likely a result of the commercial-level turtle fishing, they do support the contention that domestic consumption of sea turtle meat was popular in the area and time period under investigation. Based on these accounts and the reported volume of turtle meat processed between 1870 and 1900, the deposits encountered during the present investigations of the proposed visitor's center parking lot are most likely related to domestic consumption of the residents of the Fulton Mansion during this time period. CAS contends that the sea turtle deposits encountered during the current investigations constitute a contributing element to the NRHP listed Fulton Mansion under Criteria D (36 CFR 60.4).

The uncovering of animal carcass faunal remain deposits of green sea turtles during the previous and current investigations document the domestic consumption of turtle meat outside of and separate from the local turtle meat canning industry. Sea turtles were originally attracted to the area, due to the refuse runoff from the local cattle slaughtering and beef canning industry; an industry that was established in the Fulton area by George W. Fulton in 1868. In 1868, Fulton established the Carruthers-Fulton Packing Company that slaughtered cattle and processed beef for shipment in Fulton, unknowingly contributing to the increase of the local sea turtle population. This sea turtle population was eventually relied upon for economic support following the collapse of the beef processing industry in Fulton during the late 1800s. As the demand for beef processing shifted to Chicago, the local population began capturing, slaughtering and processing sea turtle meat for shipment and consumption. The turtle fishing industry and the strong demand for canned turtle soup quickly led to the demise of sea turtle populations along the coast and to this day, several species of sea turtles 
once common along the Texas coast remain on the endangered species list.

CAS contends that the turtle deposits will not be impacted by proposed construction of the visitor's center. Architectural plans drafted for the visitor's center call for 30 inches of fill to be utilitized for a pad upon which the center would be constructed. As a result of the fill placement, the deposits will be preserved in place, and no National Register eligible historic resources will be affected by the proposed developments. As such, CAS recommends that a "no historic properties affected" determination is appropriate and that the project and the enhancement funding should move forward. 


\section{References Cited}

Alinat, Gui.

2005. Home cooks, please don't mock turtle soup. St. Petersburg Times. http://www.sptimes.com/2005/04/27/news_pf/Taste/Home_cooks__please_do.shtml. Accessed 1 Jan 2010.

Andrews, Jean

1971 Sea shells of the Texas Coast. University of Texas Press, Austin, Texas.

Barnes, Virgil E.

1975 Geologic Atlas of Texas Beeville Bay City Sheet. Bureau of Economic Geology, The University of Texas at Austin.

Boardman, Richard S., Alan H. Cheetham, and Albert J. Rowell (editors)

1987 Fossil Invertebrates. Blackwell Scientific Publications. Palo Alto, California.

Bowers, George M.

1899. Bulletin of the United States Fish Commission. Vol. 18 for 1898. Government Printing Office, Washington DC.

Brown L.F. Jr., J. L. Grewton, J.H. McGowan, T.J. Evans, W.L. Fisher, and C.G. Groat

1976 Environmental Geologic Atlas of the Texas Coastal Zone-Corpus Christi Area. Bureau of Economic Geology, The University of Texas at Austin.

Butler, Philip A.

1985 Synoptic Review of the Literature on the southern oyster drill Thais haemastoma floridana. NOAA Technical Report NMFS 35:1-12.

Byrne, Jane, and Michelle Duggan (editors)

1970. A Collection of America's Favorite Recipes. Curtin Publications, New York.

Collins, Michael B.

2002 The Gault Site, Texas and Clovis Research. Athena Review 3(2):24-36.

Dewey, T. and J. Ng.

2001. "Bos taurus". Animal Diversity Web. http://animaldiversity.ummz.umich.edu/site/accounts/ information/Bos_taurus.html. Accessed 30 Dec 2009.

Doughty, Robin W.

1984. Sea turtles in Texas: a forgotten commerce. Southwestern Historical Quarterly 88(1):43-70. 
Everhart, Mike

2009 Oceans of Kansas Paleontology: Fossils from the Late Cretaceous Western Interior Sea http://www.oceansofkansas.com/. Accessed 12 Dec 2009.

Foster, W.C.

1998 The La Salle Expedition to Texas; The Journal of Henri Joutel, 1684-1687. Texas State Historical Association, Austin.

Freeman, M.D.

1995 Historical Background. In Archeological Survey and History of Mustang Island State Park, Nueces County, Texas. Texas Parks and Wildlife, Cultural Resources Program, Austin.

Frick, Michael G.

1996 A Guide for the Identification of Stranded Sea Turtles: The Eastern United States and the Gulf of Mexico. Savannah Science Museum, Inc., Special Publications No 4., Savannah, Georgia, 21 p. http://www.dnr.sc.gov/seaturtle/volres/frickidguide.pdf Accessed 19 Nov 2009.

Hammond, Charles A.,

1891 The Caranchua Tribe of Indians. Peabody Museum of American Archaeology and Ethnology Papers, Vol I, 2, Harvard University, Cambridge.

Goode, George Brown

1887. The fisheries and fishery industries of the United States, Section V: History and methods of the fisheries, Vol. II. United States Commission of Fish and Fisheries, Government Printing Office, Washington DC.

Guckina, William J. and Ramon N. Garcia

1979 Soil Survey of San Patricio and Aransas Counties Texas. United States Department of Agriculture, Soil Conservation Service, in Cooperation with Texas Agricultural Experiment Station.

Hester, T.R.

1980 A Survey of Paleo-Indian Archaeological Remains along the Texas Coast. In Papers on the Archaeology of the Texas Coast, edited by L. Highley and T.R. Hester, pp. 1-12. Special Report No. 11. Center for Archaeological Research, The University of Texas at San Antonio.

Ladies of Toronto and Chief Cities and Towns in Canada,

1877. The Canadian Home Cook Book. Hunter, Rose and Co. Toronto, Canada.

Lehmean, Thomas M. and Susan L. Tomlinson

2004 Terlinguachelys fischbecki, a New Genus and Species of Sea Turtle (Chelonioidea:

Protostegidae) from the Upper Cretaceous of Texas. Journal of Paleontology 78(6):1163-1178. 
Long, C.

n.d. Aransas County, Handbook of Texas Online. http://www.tsha.utexas.edu/handbook/online/ articles/CC/hcc2.html. Accessed 5 Oct 2009.

Martin, George C.

1930 Preliminary Archaeological Survey of a Portion of the Texas Coast made by George C. Martin and Wendell H. Potter in 1927, 1928, 1929; Part No. 2, Live Oak Peninsula, Puerto Bay, Rincon Ranch, and the Mouth of the Aransas River.

McClenny, Jon, Melissa Voelinger, and J. David Ing

1978 Fulton Mansion State Historic Structure Fulton, Texas 41 AS79 Archeological Monitoring and Testing. Texas Parks and Wildlife Department Historic Sites Branch.

Park, I.

2000 "Malaclemys terrapin" (On-line), Animal Diversity Web. Accessed January 15, 2010 at http:// animaldiversity.ummz.umich.edu/site/accounts/information/Malaclemys_terrapin.html.

Pecor, K.

2003. "Cheloniidae". Animal Diversity Web. http://animaldiversity.ummz.umich.edu/site/accounts/ information/Cheloniidae.html. Accessed 30 Dec 2009.

Peterson, Karen

2010 Comparative Vertebrate Anatomy Lab, Biology 453, University of Washington, Seattle,Winter quarter lab specimen photos. http://courses.washington.edu/chordate/hmpgbiol453.html. Accessed 01 January 2010.

Ricklis, R.A.

1993 A Model of Holocene Environmental and Human Adaptive Changes on the Central Texas Coast: Geoarchaeological Investigations at White's Point, Nueces Bay, and Surrounding Area. Coastal Archaeological Studies, Inc. Corpus Christi.

1995 Prehistoric Occupation of the Central and Lower Texas Coast: A Regional Overview. Bulletin of the Texas Archeological Society 66: 265-300.

2004 Prehistoric Occupation of the Central and Lower Texas Coast: A Regional Overview. In Prehistory of Texas, edited by T.K. Perttula. Texas A\&M University Press, College Station.

2005 Archaeological Testing at the west end of the Site 41AS5, Aransas County, Texas. Coastal Environments, Inc. Corpus Christi.

Ricklis, R.A. and M.D. Blum

1997 The Geoarchaeological Record of Sea Level Change and Human Occupation of the Texas Gulf Coast. Geoarchaeology: An International Journal 12(4):287-314. 
Ricklis, R.A. and K.A. Cox

1991 Examining Lithic Technology Organization as a Dynamic Cultural Subsystem: The Advantages of an Explicitly Spatial Approach. American Antiquity 58(3):444-461.

Ringstaff, Christopher W.

2008 Interim Report for: Archeological Testing at Fulton Mansion State Historic Site 41 AS79 for the Proposed Fulton Mansion Visitors Center, Aransas County, Texas. CSJ 0916-38-005, TxDOT Corpus Christi District.

Stanley, Jon G. and Mark A. Sellers.

1986 Species Profiles: Life Histories and Environmental Requirements of Coastal Fishes and Invertebrates (Gulf of Mexico)--American Oyster. U.S. Fish and Wildlife Service Biology Report, 82 (11.84) U.S. Army Corps of Engineers, TR EL-82-4. 25 pp.

Stevenson, C.H.

1893 Report on coast fisheries of Texas.

Story, D.A.

1968 Archeological Investigations at Two Central Texas Gulf Coast Sites. State Building Commission Report No. 13, Austin.

Suhm, D.A. and E.B. Jelks

1962 Handbook of Texas Archaeology: Type Descriptions. Archaeological Society Special Publication No. 1 and Texas Memorial Museum Bulletin No. 4.

Timperley, C., P. R. Owen, and E. L. Lundelius, Jr.

2003 Preliminary Comments on Faunal Material from the Gault Site, Central Texas. Current Research in the Pleistocene 20:117-119.

Todd, Lawrence C.

2001 Zooarchaeology, Colorado State University AP465. http://lamar.colostate.edu/ lctodd/ zooarch.htm. Accessed 13 Nov 2009.

Townsend, C.H.

1899 Statistics of the Fisheries of the Gulf States.

Turner, E. and T.R. Hester

1993 A Field Guide to Stone Artifacts of the Texas Indians. Third Edition, Gulf Publishing Company, Houston. 
Valente, Ana Luisa, Ignasi Marco, Maria Angeles Zamora, Maria Luz Parga, Santiago Lavin, Ferran Alegre, Rafaela Cuenca

2007 Radiographic features of the limbs of juvenile and subadult loggerhead sea turtles (Caretta caretta). The Canadian Journal of Veterinary Research 71:305-313.

Walraven, Bill.

1985. Rare turtles were once industry, 14 November, Corpus Christi Caller Times.

Wyneken, Jeanette.

2001 The Anatomy of Sea Turtles, 1-172 pp, U.S. Department of Commerce NOAA Technical Memorandum NM-SEFSC-470.

Zangerl, R. and R. E. Sloan.

1960. A new species of Desmatochelys lowi Williston, a primitive cheloniid sea turtle from the Cretaceous of South Dakota. Fieldiana: Geology. 14:7-40. 
Appendix A

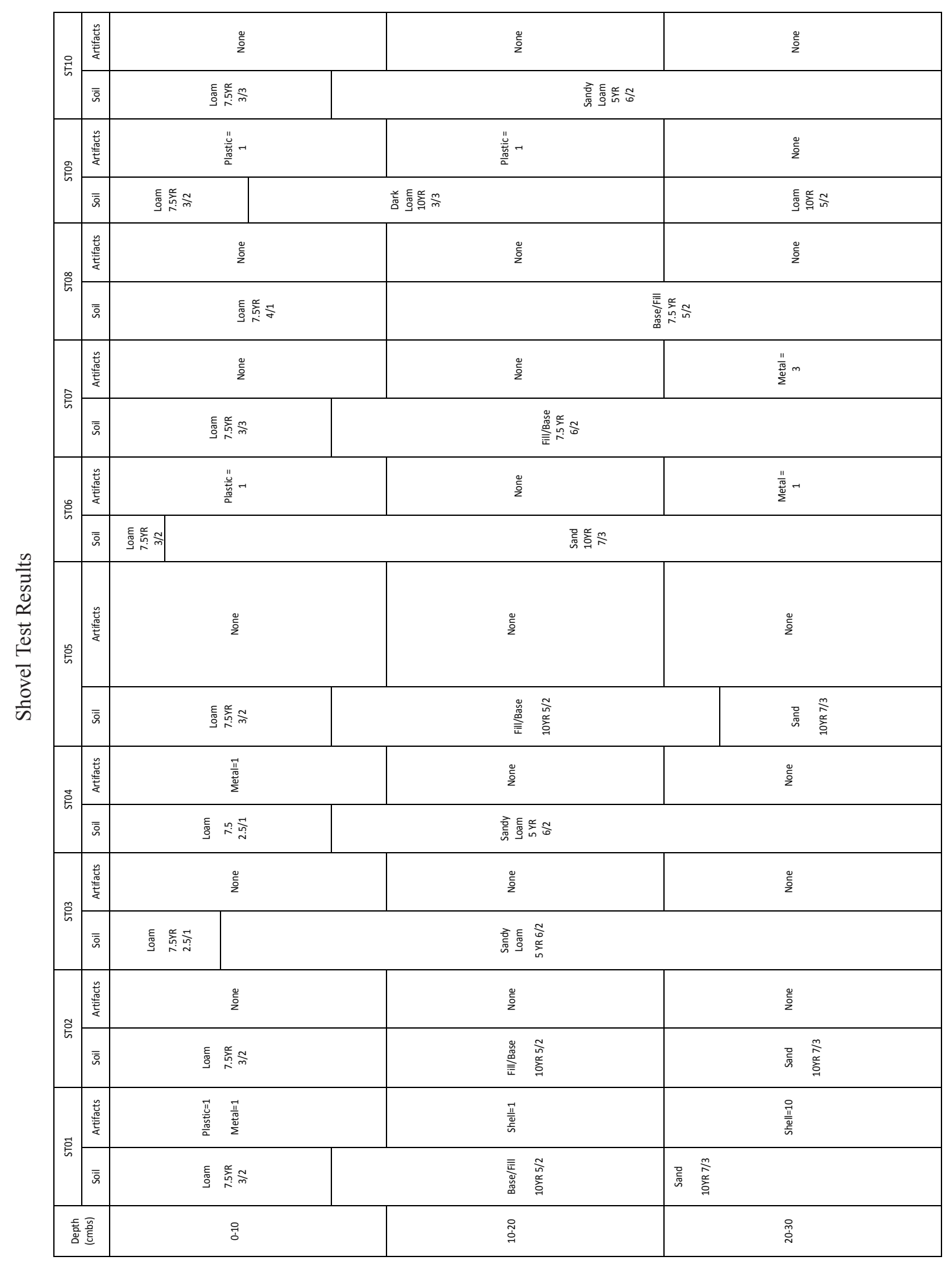




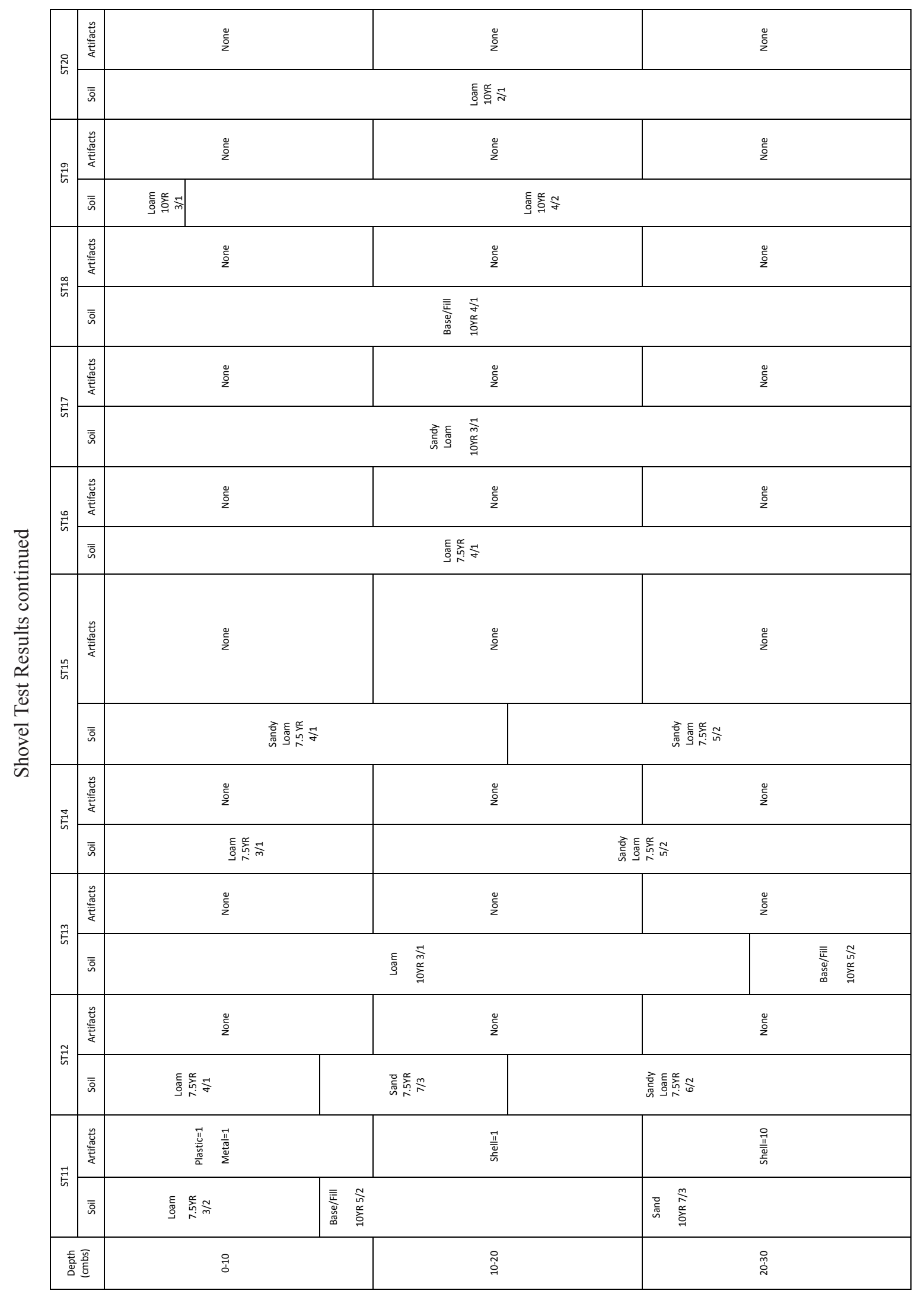




\section{Appendix B}

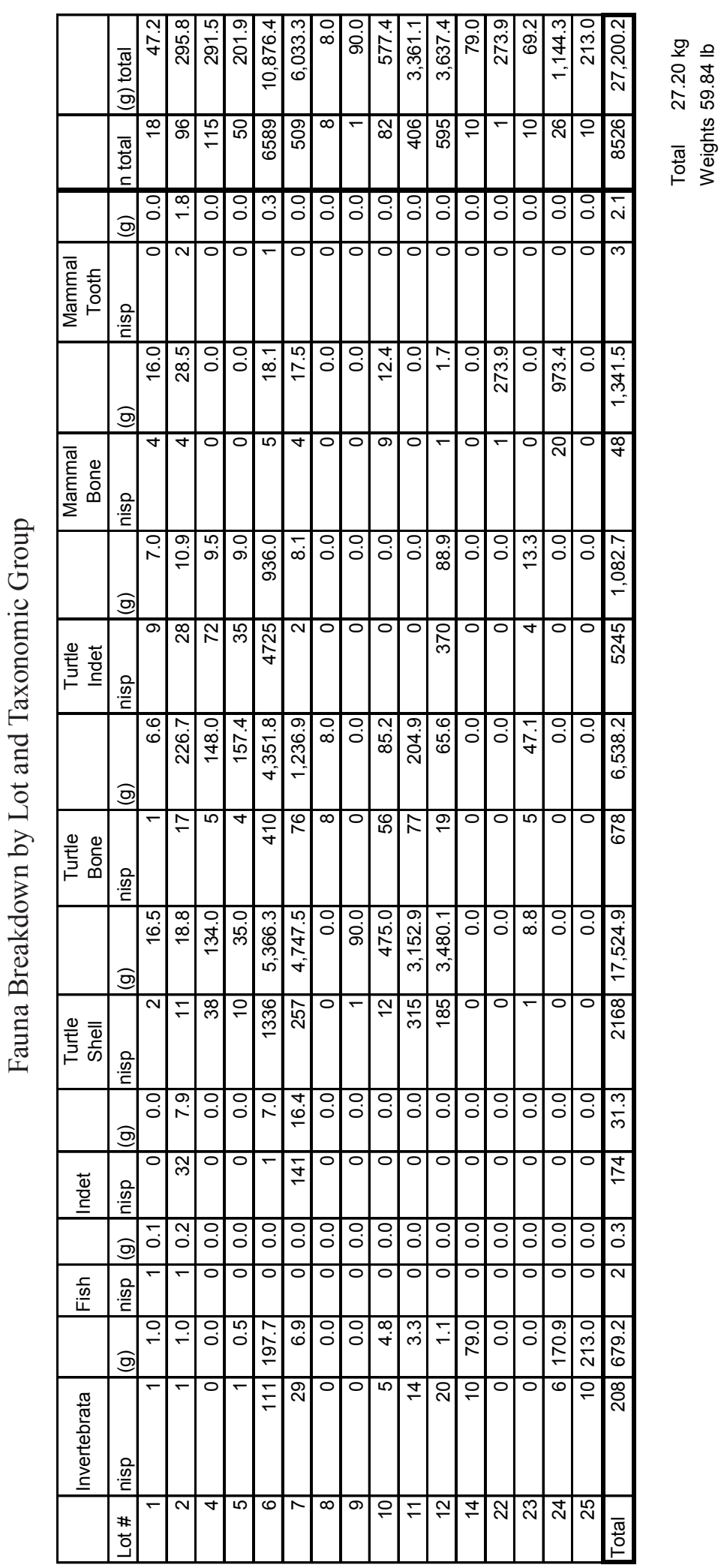




\section{APPENDix C}

Faunal Assemblage Summary

\begin{tabular}{|c|c|c|c|c|c|c|c|c|}
\hline Trench & Unit & Level (cmbs) & Lot & Spec\# & Taxon & Element(s) & $n$ & $g$ \\
\hline \multirow[t]{5}{*}{ EBHT } & XU01 & $1(51-74 \mathrm{~cm})$ & 1 & & Mollusca & 1 valve fragment & 1 & 1 \\
\hline & & & & 2 & Osteichthys & 1 vertebra & 1 & 0.1 \\
\hline & & & & & Cheloniidae & fragments & 11 & 10 \\
\hline & & & & 1 & Cheloniidae & 1 cut rib fragment & 1 & 6.6 \\
\hline & & & & & Mammalia cf. Bos sp. & $\begin{array}{l}1 \text { indet bone fragment ( } 2 \text { fragments mend) with saw- } \\
\text { cut end; } 3 \text { indet fragments }\end{array}$ & 4 & 16 \\
\hline \multirow[t]{6}{*}{ EBHT } & XU01 & 2 (74-85 cmbs) & 2 & & Mollusca & 1 valve fragment & 1 & 1 \\
\hline & & & & 1 & Osteichthys & 1 skull bone & 1 & 0.2 \\
\hline & & & & & Cheloniidae & 7 indeterminate shell fragments & 7 & 9.6 \\
\hline & & & & & Mammalia & 3 skull fragments & 3 & 16.2 \\
\hline & & & & & Bos sp. & fragments & 3 & 14.1 \\
\hline & & & & & Indeterminate & 32 indet bone fragment & 32 & 7.9 \\
\hline \multirow[t]{4}{*}{ EBHT } & $\begin{array}{l}\text { XU01 } \\
\text { Unproven. } \\
\text { East wall }\end{array}$ & $80 \mathrm{cmbs}$ & 2 & & Cheloniidae & $\begin{array}{l}5 \text { coracoid fragments; } 2 \text { femoral head(?) fragments } \\
\text { (mend); } 1 \text { scapular glenoid (left), scavenged, cut; } 28 \\
\text { indet frags, } 4 \text { indet shell fragments }\end{array}$ & 40 & 115.5 \\
\hline & & & & 2 & cf. Chelonia mydas & 1 scapula base, cut and scavenged & 1 & 22.4 \\
\hline & & & & 3 & cf. Chelonia mydas & 7 coracoid fragments (right), mends, cuts & 7 & 49.9 \\
\hline & & & & 4 & cf. Chelonia mydas & 1 left scapula-acromion unit, incomplete & 1 & 59 \\
\hline \multirow[t]{4}{*}{ EBHT } & XU01 & $3(85-93 \mathrm{cmbs})$ & 4 & 2 & cf. Dermochelys coriacea & 1 ilium, cut & 1 & 43 \\
\hline & & & & & Cheloniidae & fragments & 110 & 143.5 \\
\hline & & & & 1 & Cheloniidae & 1 phalanx & 1 & 2 \\
\hline & & & & 3 & Cheloniidae & 3 scapula-acromion cut & 3 & 103 \\
\hline \multirow[t]{3}{*}{ EBHT } & XU01 & $3(85-93 \mathrm{cmbs})$ & 5 & & Mollusca & 1 valve fragment & 1 & 0.9 \\
\hline & & & & & Cheloniidae & $\begin{array}{l}1 \text { humerus fragment, side indeterminate; } 1 \text { plastron } \\
\text { fragment, mends; } 4 \text { peripheral fragments; } 1 \text { carpal or } \\
\text { tarsal; } 1 \text { scapula fragment; } 35 \text { indeterminate bone } \\
\text { fragments }\end{array}$ & 48 & 61.6 \\
\hline & & & & 1 & Chelonia mydas & 1 humerus, left, cut & 1 & 139.8 \\
\hline \multirow[t]{10}{*}{ EBHT } & XU01 & 4 (93-112 cmbs) & 6 & & Coral & 1 fragment & 1 & 0.3 \\
\hline & & & & & Mollusca & 75 indeterminate bivalve fragments & 75 & 21.8 \\
\hline & & & & & Mollusca & 4 indeterminate bivalve fragments, burned & 4 & 0.8 \\
\hline & & & & & Mollusca & 1 clam umbo & 1 & 0.5 \\
\hline & & & & & Mollusca:Lucina sp. & 1 complete valve; 5 valve fragments & 6 & 3.8 \\
\hline & & & & & Crassostrea virginica & 12 valve fragments & 12 & 154.4 \\
\hline & & & & & Ostreidae: cf. Crassostrea & 7 valve fragments & 7 & 3.8 \\
\hline & & & & & cf. Gryphaea & 4 valve fragments & 4 & 5.3 \\
\hline & & & & & $\begin{array}{l}\text { cf. Rangia (Rangianella) } \\
\text { flexuosa }\end{array}$ & 1 complete Brown Rangia bivalve & 1 & 7 \\
\hline & & & & & Cheloniidae & $\begin{array}{l}19 \text { humerus fragments; } 92 \text { undifferentiated podials; } 15 \\
\text { scapula fragments; } 16 \text { acromion fragments; } 2 \text { coracoid } \\
\text { fragments; } 4 \text { indeterminate pectoral fragments; } 2 \\
\text { glenoid fragments; } 3 \text { limb element fragments; } 1 \text { pubis } \\
\text { fragment; } 2 \text { ilia, scavenged; } 13 \text { vertebral fragments; } 25 \\
\text { rib fragments; } 7 \text { skull fragments; } 182 \text { non-shell } \\
\text { fragments; } 379 \text { identified plastron, peripheral, and } \\
\text { pleural fragments; } 44 \text { cemented indeterminate } \\
\text { fragments; } 913 \text { shell fragments, undifferentiated.; } 4725 \\
\text { (minimum) indeterminate skeletal material }\end{array}$ & & 8414.7 \\
\hline
\end{tabular}


Faunal Assemblage Summary continued

\begin{tabular}{|c|c|c|c|c|c|c|c|c|}
\hline Trench & Unit & Level (cmbs) & Lot & Spec\# & Taxon & Element(s) & n & g \\
\hline EBHT & $\mathrm{XU01}$ & 4 (93-112 cmbs) & 6 & 2 & cf. Chelonia mydas & 1 humerus (left), proximal portion, cut & 1 & 147 \\
\hline \multicolumn{4}{|c|}{ (continued from previous page) } & 3 & cf. Chelonia mydas & 1 humerus (left), shaft, cut & 1 & 139.9 \\
\hline & & & & 8 & cf. Chelonia mydas & 2 humerus fragments (right), mend, cuts & 2 & 111.7 \\
\hline & & & & 9 & cf. Chelonia mydas & 1 radius & 1 & 30.5 \\
\hline & & & & 10 & cf. Chelonia mydas & 1 scapula-acromion (left), cuts & 1 & 111.2 \\
\hline & & & & 11 & cf. Chelonia mydas & 1 coracoid with glenoid (left), mends with 6-12 & 1 & 73 \\
\hline & & & & 12 & cf. Chelonia mydas & $\begin{array}{l}1 \text { scapula-acromion base/glenoid (left), mends with 6- } \\
11\end{array}$ & 1 & 32.9 \\
\hline & & & & 13 & cf. Chelonia mydas & 2 scapula-acromion and glenoid, mends, cuts & 2 & 86.4 \\
\hline & & & & 14 & cf. Chelonia mydas & 1 scapula-acromion (right), cuts & 1 & 82.2 \\
\hline & & & & 15 & cf. Chelonia mydas & 1 coracoid (left), broken, carnivore damage & 1 & 73.9 \\
\hline & & & & 16 & cf. Chelonia mydas & 1 coracoid (left), fragment & 1 & 36.1 \\
\hline & & & & 17 & cf. Chelonia mydas & 1 coracoid (right) & 1 & 70 \\
\hline & & & & 18 & cf. Chelonia mydas & 1 pubis (right) & 1 & 60.2 \\
\hline & & & & 19 & cf. Chelonia mydas & 1 pubis (right), cuts on lateral edge & 1 & 38.9 \\
\hline & & & & 20 & cf. Chelonia mydas & 1 pubis (left), fragment & 1 & 20 \\
\hline & & & & 21 & cf. Chelonia mydas & 2 ilium fragments (left), mend, cuts & 2 & 60 \\
\hline & & & & 22 & cf. Chelonia mydas & 1 cervical vertebra, cuts & 1 & 19.4 \\
\hline & & & & 1 & Chelonia mydas & 1 humerus (left), cuts & 1 & 232.2 \\
\hline & & & & 4 & Chelonia mydas & 1 humerus (right), cuts & 1 & 204.2 \\
\hline & & & & 5 & Chelonia mydas & 1 humerus (right), cuts & 1 & 179.5 \\
\hline & & & & 6 & Chelonia mydas & 1 humerus (right) in 2 pieces, mend, cut & 2 & 213.4 \\
\hline & & & & 7 & Chelonia mydas & 1 humerus (right) in 2 pieces, mend, cut & 2 & 216.5 \\
\hline & & & & & Mammalia & 1 petrosal & 1 & 15.8 \\
\hline & & & & & Mammalia & 4 indeterminate bone fragments & 4 & 2.3 \\
\hline & & & & & cf. Bos taurus & tooth fragment & 1 & 0.3 \\
\hline & & & & & Indeterminate vertebrate & 1 burned bone fragment & 1 & 6.5 \\
\hline $\begin{array}{l}\text { Southern } \\
\text { EBHT }\end{array}$ & & Backhoe fill & 7 & & Mollusca & 29 shell fragments & 29 & 6.9 \\
\hline & & & & & Cheloniidae & $\begin{array}{l}40 \text { pleural fragments, some mends; } 1 \text { vertebra } \\
\text { fragment; } 10 \text { peripheral bones, some mends; } 25 \text { non- } \\
\text { shell postcranial fragment; } 3 \text { rib fragments, mends; } 15 \\
\text { rib fragments, no mends; } 1 \text { glenoid fragment; } 1 \text { nuchal } \\
\text { fragment?; } 2 \text { coracoid fragments; } 1 \text { femur fragment?; } 2 \\
\text { indet bone fragments; } 1 \text { indet diseased bone fragment; } \\
1 \text { pubis fragment?; } 3 \text { indet skull fragments; } 127 \\
\text { undifferentiated shell fragments; } 16 \text { plastron fragment, } \\
\text { some mends }\end{array}$ & 249 & 2859.1 \\
\hline & & & & & cf. Chelonia mydas & $\begin{array}{l}1 \text { skull bone; } 2 \text { coracoid fragments, mend; } 39 \text { pleural } \\
\text { fragments, some mends; } 1 \text { pleural fragment (right); } 17 \\
\text { left pleural fragments (left) }\end{array}$ & 61 & 1772.8 \\
\hline & & & & 4 & cf. Chelonia mydas & 1 quadrate? & 1 & 9.4 \\
\hline & & & & 5 & cf. Chelonia mydas & 1 parietal (left) frag, mend & 1 & 11 \\
\hline & & & & 7 & cf. Chelonia mydas & 1 supraoccipital fragment & 1 & 4.7 \\
\hline & & & & 8 & cf. Chelonia mydas & 1 glenoid & 1 & 85.6 \\
\hline & & & & 9 & cf. Chelonia mydas & 3 coracoid fragments, mend & 3 & 117 \\
\hline & & & & 13 & cf. Chelonia mydas & 1 humerus (right), medial process & 1 & 47.3 \\
\hline & & & & 14 & cf. Chelonia mydas & 1 radius, pathological proximal end & 1 & 37.6 \\
\hline & & & & 15 & cf. Chelonia mydas & 1 radius, some scavenging & 1 & 68.4 \\
\hline & & & & 16 & cf. Chelonia mydas & 2 peripheral fragments & 2 & 130.6 \\
\hline & & & & & caretta & 1 hypoplastron fragment & 1 & 193.6 \\
\hline & & & & 1 & Chelonia mydas & 1 prefrontal (left) & 1 & 5.9 \\
\hline & & & & 2 & Chelonia mydas & 1 prefrontal (right) & 1 & 5.6 \\
\hline & & & & 3 & Chelonia mydas & 1 maxilla (right) & 1 & 9.5 \\
\hline & & & & 6 & Chelonia mydas & 2 squamosal fragments (right), mend & 2 & 12.2 \\
\hline & & & & 10 & Chelonia mydas & 1 coracoid (left), some scavenging & 1 & 120.9 \\
\hline & & & & 11 & Chelonia mydas & 3 humerus fragments (left), mend & 3 & 254.1 \\
\hline & & & & 12 & Chelonia mydas & 1 humerus (left), cut, scavenged & 1 & 202.9 \\
\hline & & & & & Chelonia mydas & 2 pleural fragment, proximal end, mend & 2 & 44.3 \\
\hline & & & & & Mammalia & 4 bone fragments & 4 & 17.5 \\
\hline & & & & & Indeterminate vertebrate & 141 indeterminate bone fragments & 141 & 16.4 \\
\hline
\end{tabular}


Faunal Assemblage Summary continued

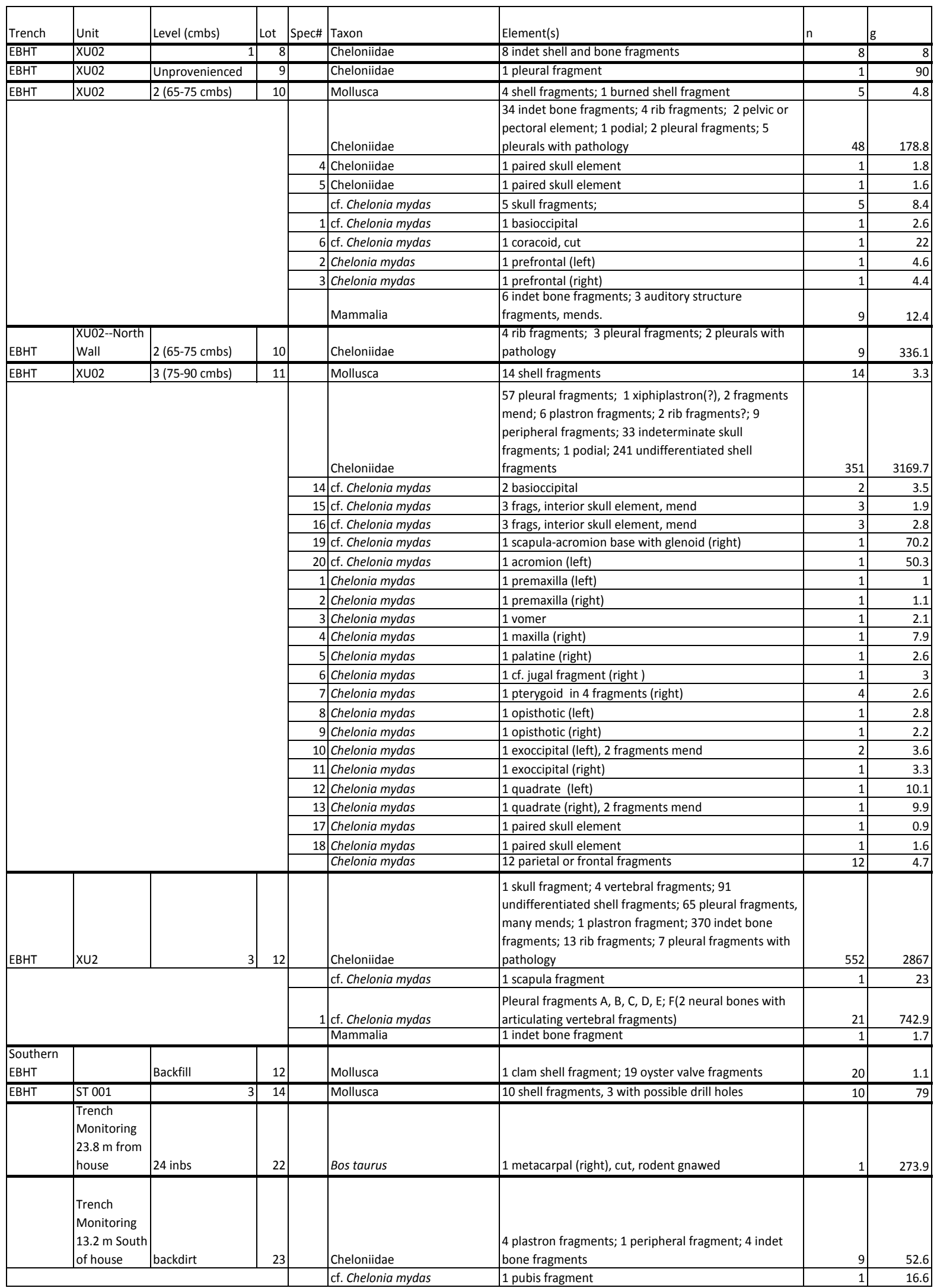


Faunal Assemblage Summary continued

\begin{tabular}{|c|c|c|c|c|c|c|c|c|}
\hline \multirow[t]{2}{*}{ Trench } & Unit & Level (cmbs) & Lot & Spec\# & Taxon & Element(s) & $n$ & $\mathrm{~g}$ \\
\hline & Bore Hole B & $2(15-40 \mathrm{cmbs})$ & 24 & & Mollusca & 1 gastropod? Shell fragment & 1 & 3 \\
\hline & & & & & cf. Crassostrea sp. & 3 valves & 3 & 167 \\
\hline & & & & & Crustacea & 2 crab claws & 2 & 0.9 \\
\hline & & & & & Mammalia & 1 indeterminate bone fragment; 1 juvenile vertebra & 2 & 7.9 \\
\hline & & & & & Bos taurus & $\begin{array}{l}3 \text { subadult left ankle bones: calcaneum, astragalus, } \\
\text { fused } 3 \text { rd and } 4 \text { th tarsal; } 1 \text { left humerus unfused distal } \\
\text { epiphysis; } 1 \text { subadult possibly proximal end of tibia; } 1 \\
\text { rib fragment; } 2 \text { ulnae; } 1 \text { ilium with cuts, rodent and } \\
\text { carnivore gnaws; } 1 \text { subadult humerus, distal end; } 2 \\
\text { juvenile ulna and unfused olecranon tuber, naturally } \\
\text { separated; } 1 \text { left radius, proximal end; } 3 \text { left carpals: } \\
\text { radial, fused } 2 \text { nd and } 3 \text { rd, intermediate; } 2 \text { left radius } \\
\text { with unfused distal epiphysis }\end{array}$ & 18 & 965.5 \\
\hline & Trench 1 & $\begin{array}{l}\text { Backfill (up to } 122 \\
\text { cmbs) }\end{array}$ & 25 & & Mollusca & $\begin{array}{l}1 \text { gastropod, complete shell; Mussel } 6 \text { valve fragments; } \\
\text { Oyster } 3 \text { valves }\end{array}$ & 10 & 213 \\
\hline
\end{tabular}




\section{Appendix D}

\begin{tabular}{|c|c|c|c|c|c|c|c|c|c|c|c|c|c|c|c|c|c|}
\hline 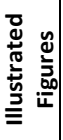 & & & & & & & & & & & & 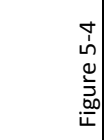 & & & & & \\
\hline 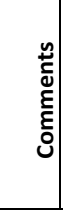 & 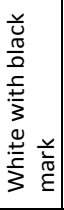 & 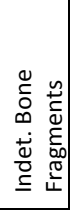 & 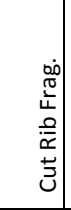 & 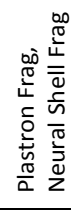 & 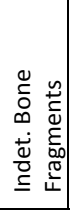 & 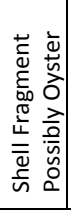 & $\begin{array}{l}\frac{\pi}{0} \\
\frac{0}{0} \\
\frac{5}{9} \\
>\end{array}$ & & & 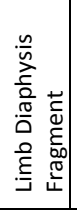 & 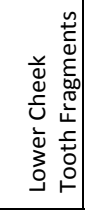 & 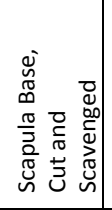 & 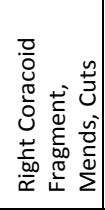 & 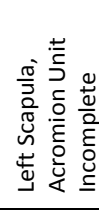 & 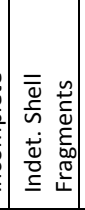 & 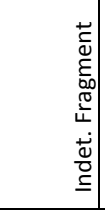 & 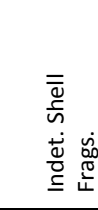 \\
\hline 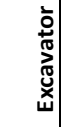 & 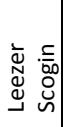 & 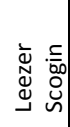 & 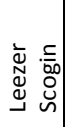 & 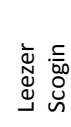 & 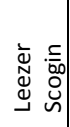 & 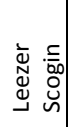 & 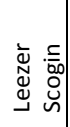 & 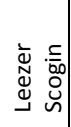 & 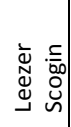 & 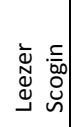 & 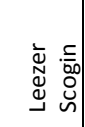 & 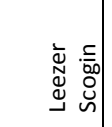 & 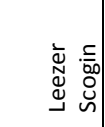 & 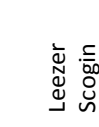 & 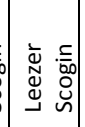 & 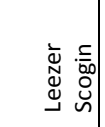 & 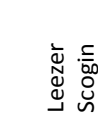 \\
\hline 器 & $m$ & $\stackrel{\bullet}{-1}$ & $\begin{array}{l}\varphi_{0} \\
\end{array}$ & $m$ & $N$ & -1 & - & $\sigma$ & $N$ & 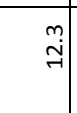 & $\stackrel{\infty}{\rightarrow}$ & $\stackrel{+}{\stackrel{\sim}{N}}$ & $\begin{array}{l}\sigma \\
\dot{g} \\
\dot{q}\end{array}$ & in & ○ْ. & $\begin{array}{l}0 \\
\stackrel{9}{0} \\
-1\end{array}$ & $\stackrel{\sim}{\sigma}$ \\
\hline $\overrightarrow{\mathrm{s}}$ & 7 & $\nabla$ & 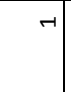 & $\sim$ & $\sigma$ & $\rightarrow$ & 7 & $N$ & $\rightarrow$ & 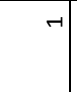 & $\sim$ & $\rightarrow$ & $\wedge$ & - & $\wedge$ & $\stackrel{\infty}{\sim}$ & † \\
\hline $\begin{array}{l}\tilde{y} \\
\frac{\tilde{\sigma}}{U}\end{array}$ & & $\begin{array}{l}\dot{0} \\
\overline{0} \\
\infty \\
\dot{U}\end{array}$ & 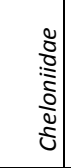 & 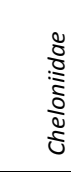 & $\begin{array}{l}8 \\
: \\
: \vdots \\
\frac{0}{8} \\
\tilde{u}\end{array}$ & 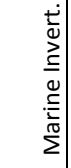 & 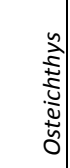 & $\begin{array}{l}\frac{0}{\pi} \\
\frac{5}{5} \\
\end{array}$ & $\begin{array}{l}5 \\
\vdots \\
0 \\
5 \\
5\end{array}$ & 今. & $\begin{array}{l}\tilde{o} \\
\infty\end{array}$ & 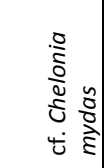 & 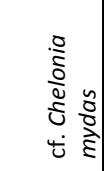 & 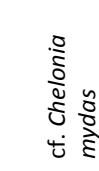 & 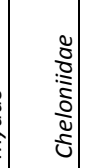 & 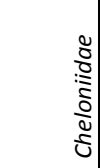 & 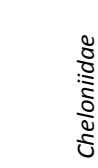 \\
\hline 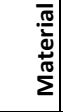 & 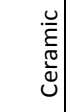 & 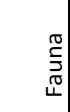 & 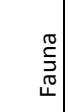 & 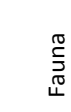 & 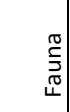 & 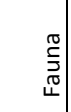 & 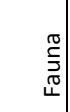 & $\begin{array}{l}\overline{\frac{\pi}{0}} \\
\frac{\mathrm{d}}{2}\end{array}$ & 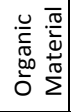 & 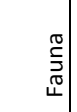 & 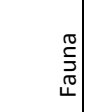 & 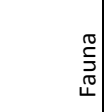 & 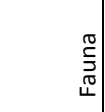 & 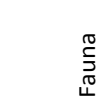 & 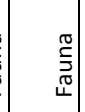 & 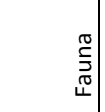 & 胥 \\
\hline 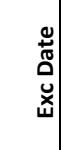 & 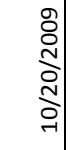 & $\begin{array}{l}0 \\
0 \\
0 \\
0 \\
0 \\
-1\end{array}$ & 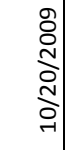 & 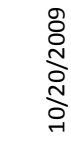 & $\begin{array}{l}0 \\
0 \\
\vdots \\
0 \\
0 \\
\text { - }\end{array}$ & $\begin{array}{l}\text { o } \\
0 \\
0 \\
0 \\
0\end{array}$ & $\begin{array}{l}0 \\
0 \\
\vdots \\
0 \\
0 \\
\text { - }\end{array}$ & 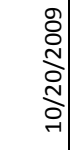 & $\begin{array}{l}0 \\
0 \\
0 \\
0 \\
0 \\
\text { - }\end{array}$ & 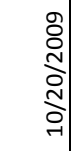 & 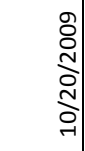 & 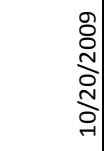 & $\begin{array}{l}0 \\
0 \\
0 \\
0 \\
0 \\
\text { - }\end{array}$ & 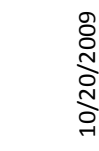 & 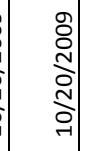 & 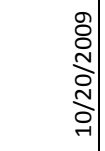 & 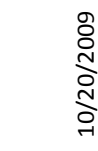 \\
\hline 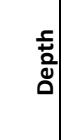 & 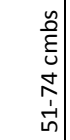 & 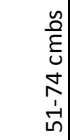 & 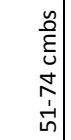 & 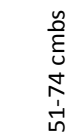 & 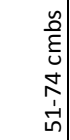 & 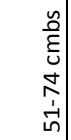 & 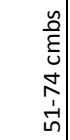 & 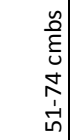 & 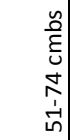 & 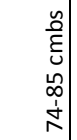 & 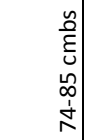 & $\begin{array}{l}0 \\
\hat{\xi} \\
0 \\
\infty\end{array}$ & $\begin{array}{l}0 \\
0 \\
\varepsilon_{0} \\
0 \\
\infty\end{array}$ & $\begin{array}{l}\text { ڤै } \\
\text { है } \\
\text { ○ }\end{array}$ & 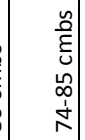 & 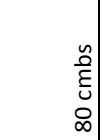 & 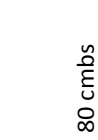 \\
\hline$\stackrel{\overline{\mathrm{v}}}{\mathrm{d}}$ & 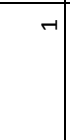 & $\rightarrow$ & $\rightarrow$ & -1 & $\rightarrow$ & $\rightarrow$ & $\rightarrow$ & $\neg$ & $\rightarrow$ & $N$ & $\sim$ & & & & $N$ & & \\
\hline$\stackrel{\mathrm{z}}{5}$ & 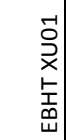 & 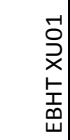 & 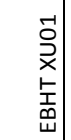 & 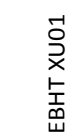 & 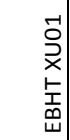 & $\begin{array}{l}\overrightarrow{0} \\
\mathbf{x} \\
\mathbf{t} \\
\underline{m} \\
\text { w }\end{array}$ & 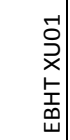 & 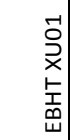 & 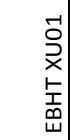 & 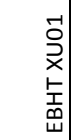 & 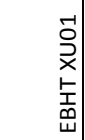 & 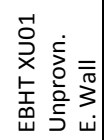 & 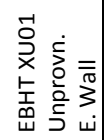 & 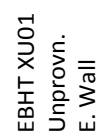 & 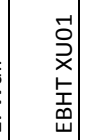 & 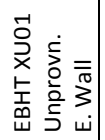 & 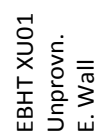 \\
\hline$\dot{\grave{\Xi}}$ & & & $r$ & & & & $\sim$ & & & & & $\sim$ & $m$ & $\sigma$ & & & \\
\hline 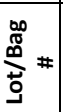 & -1 & -1 & 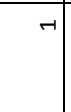 & -1 & $\neg$ & $\rightarrow$ & $\rightarrow$ & $\rightarrow$ & $\rightarrow$ & $N$ & $\sim$ & $N$ & $\sim$ & & $\sim$ & $\sim$ & $\sim$ \\
\hline
\end{tabular}




\begin{tabular}{|c|c|c|c|c|c|c|c|c|c|c|c|c|c|c|c|c|}
\hline 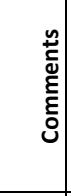 & 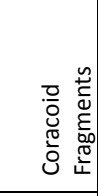 & 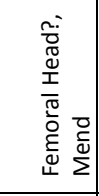 & 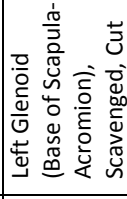 & 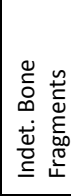 & 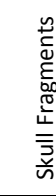 & 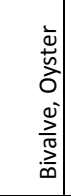 & 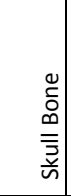 & & 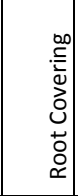 & $\begin{array}{l}\overline{0} \\
\frac{0}{5} \\
\vdots \\
0 \\
5 \\
5\end{array}$ & 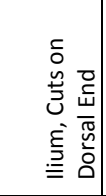 & $\begin{array}{l} \\
\times \\
\frac{x}{\pi} \\
\frac{\pi}{\frac{\pi}{0}} \\
\frac{0}{0}\end{array}$ & 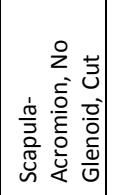 & 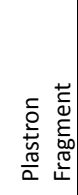 & 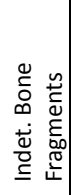 & 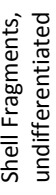 \\
\hline 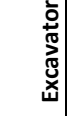 & 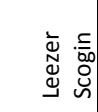 & 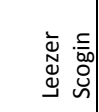 & 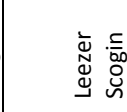 & 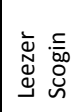 & 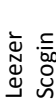 & 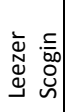 & 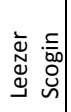 & 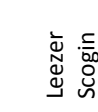 & 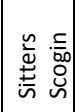 & 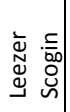 & 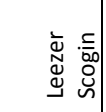 & 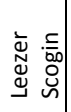 & 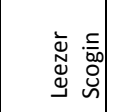 & 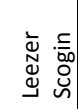 & 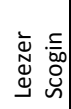 & 离 \\
\hline 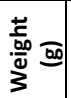 & $\overrightarrow{\mathrm{i}}$ & ڤ્. & ه্ & $\stackrel{\circ}{r}$ & No & 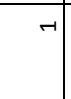 & ก̃. & -1 & $\begin{array}{l}m \\
0\end{array}$ & in & $q$ & $N$ & 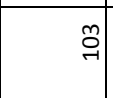 & $m$ & นn & $\overrightarrow{9}$ \\
\hline 志 & in & $\sim$ & -1 & $\stackrel{\sim}{m}$ & $m$ & $\rightarrow$ & 7 & - & $\sim$ & $\sim$ & -1 & $\neg$ & $m$ & -1 & $N$ & $\hat{m}$ \\
\hline $\begin{array}{l}\tilde{a} \\
\tilde{\tilde{d}}\end{array}$ & 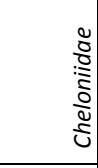 & 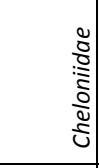 & 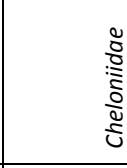 & 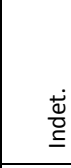 & $\begin{array}{l}\overline{\widetilde{g}} \\
\tilde{\varepsilon}^{\mathrm{E}} \\
\sum^{\pi}\end{array}$ & 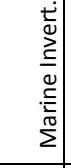 & 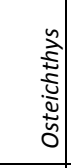 & $\begin{array}{l}\text { ] } \\
\text { ஸे } \\
\end{array}$ & 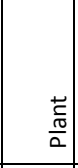 & & 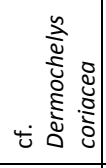 & $\begin{array}{c}0 \\
0 \\
: \\
\vdots \\
0 \\
2 \\
5\end{array}$ & 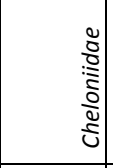 & 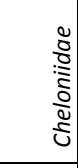 & 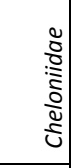 & 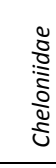 \\
\hline $\begin{array}{c}\bar{\sigma} \\
\overline{\frac{\pi}{4}} \\
\bar{\pi} \\
\Sigma \\
\end{array}$ & $\begin{array}{l}\sqrt[\pi]{5} \\
\stackrel{5}{5} \\
\stackrel{5}{5} \\
\end{array}$ & $\begin{array}{c}\tilde{\sigma} \\
\stackrel{0}{\sigma} \\
\tilde{\omega} \\
\end{array}$ & 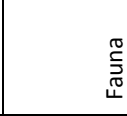 & 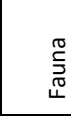 & 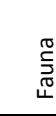 & 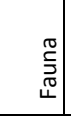 & 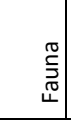 & 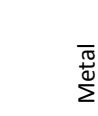 & 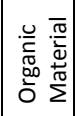 & 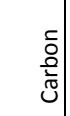 & 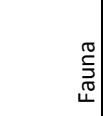 & 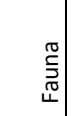 & 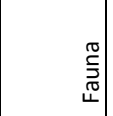 & 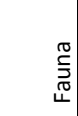 & 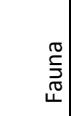 & $\begin{array}{l}\text { 节 } \\
\text { 苂 }\end{array}$ \\
\hline 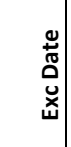 & 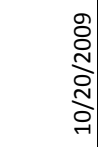 & 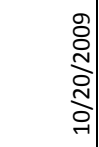 & 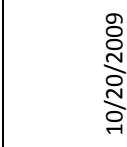 & 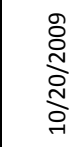 & 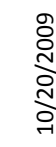 & 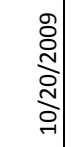 & 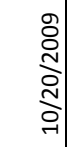 & 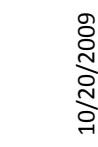 & 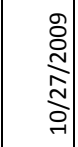 & 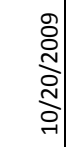 & 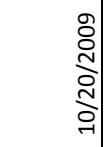 & 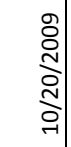 & 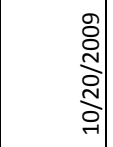 & 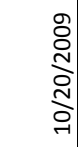 & 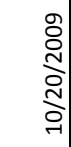 & $\begin{array}{l}\stackrel{8}{0} \\
\text { D̀ } \\
\text { o }\end{array}$ \\
\hline $\begin{array}{l}\mathbf{f} \\
\bar{a} \\
\Delta\end{array}$ & $\begin{array}{l}\text { م } \\
\text { है } \\
0 \\
\infty\end{array}$ & $\begin{array}{l}\text { مै } \\
\text { है } \\
0 \\
\infty\end{array}$ & $\begin{array}{l}\text { है } \\
\text { है } \\
\text { ठ }\end{array}$ & 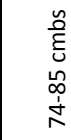 & $\begin{array}{l}\stackrel{\Delta}{0} \\
\text { है } \\
\stackrel{L}{\infty} \\
\stackrel{+}{N}\end{array}$ & 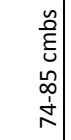 & 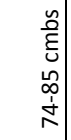 & $\begin{array}{l}\text { है } \\
\text { है } \\
\text { D }\end{array}$ & $\begin{array}{l}\text { है } \\
\text { है } \\
0 \\
0\end{array}$ & 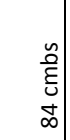 & $\begin{array}{c}0 \\
\stackrel{0}{0} \\
\underline{\xi} \\
0 \\
0 \\
\dot{\omega} \\
\infty\end{array}$ & 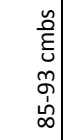 & 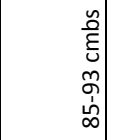 & 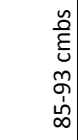 & 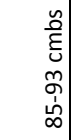 & $\begin{array}{l}\text { है } \\
\bar{E} \\
\tilde{N} \\
\dot{\omega} \\
\infty\end{array}$ \\
\hline$\stackrel{\bar{\Xi}}{\bar{\Xi}}$ & & & & $\sim$ & $\sim$ & $\sim$ & $N$ & & 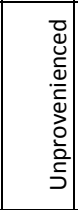 & $\sim$ & $m$ & $m$ & $m$ & $m$ & $m$ & $m$ \\
\hline$+\frac{5}{5}$ & 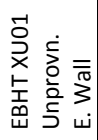 & 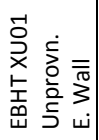 & 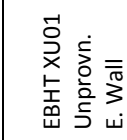 & 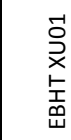 & 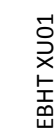 & 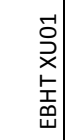 & $\begin{array}{l}\overrightarrow{0} \\
\vec{x} \\
\underline{t} \\
\underline{\mathbf{m}} \\
\underline{w}\end{array}$ & 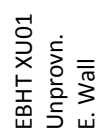 & 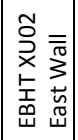 & 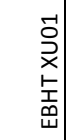 & 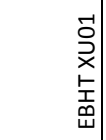 & 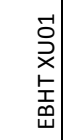 & 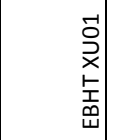 & 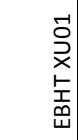 & 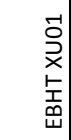 & 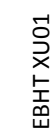 \\
\hline غٌّ & & & & & & & $\rightarrow$ & & & & $N$ & $\rightarrow$ & $m$ & & & \\
\hline 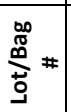 & $\sim$ & $N$ & $N$ & $\sim$ & $\sim$ & $\sim$ & $\sim$ & $N$ & $\sim$ & $m$ & $\nabla$ & $\nabla$ & $\sigma$ & $\sigma$ & $\nabla$ & 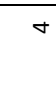 \\
\hline
\end{tabular}




\begin{tabular}{|c|c|c|c|c|c|c|c|c|c|c|c|c|c|c|c|c|c|c|c|}
\hline 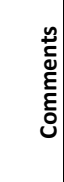 & 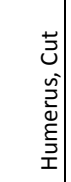 & 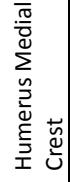 & 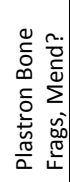 & 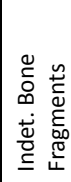 & 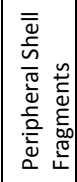 & 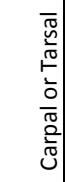 & 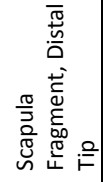 & 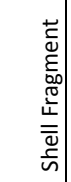 & & & & 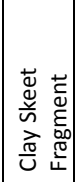 & 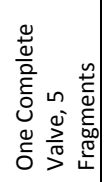 & 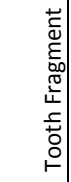 & 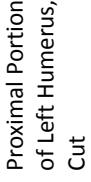 & 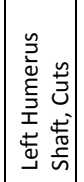 & 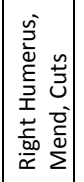 & 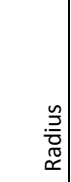 & 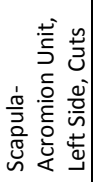 \\
\hline 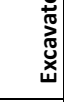 & 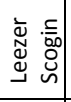 & 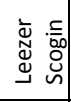 & 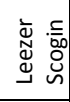 & 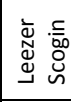 & 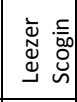 & 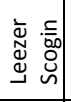 & 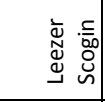 & 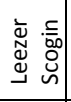 & 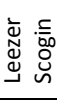 & 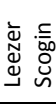 & 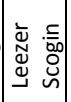 & 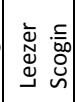 & 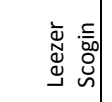 & 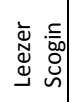 & 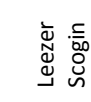 & 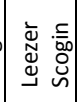 & 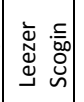 & 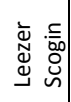 & 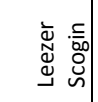 \\
\hline 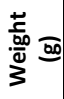 & $\begin{array}{l}\infty \\
\stackrel{0}{0} \\
\rightarrow\end{array}$ & $\begin{array}{l}\mathscr{\varphi}_{j} \\
\text { | }\end{array}$ & 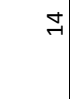 & $\sigma$ & $\vec{N}$ & $N$ & $N$ & $\vec{v}$ & $\infty$ & 6 & $r$ & n & $\stackrel{\infty}{m}$ & $\stackrel{m}{0}$ & f & 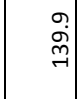 & जे & $\begin{array}{l}\text { : } \\
\stackrel{m}{.}\end{array}$ & $\underset{\exists}{\exists}$ \\
\hline 䓂 & 7 & -1 & 6 & $\stackrel{m}{m}$ & 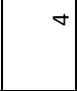 & -1 & -1 & $r$ & i & $\stackrel{\infty}{\sim}$ & $\tilde{\sim}$ & $\sim$ & 6 & $r$ & $\neg$ & $r$ & $N$ & $r$ & -1 \\
\hline
\end{tabular}

\begin{tabular}{|c|c|c|c|c|c|c|c|c|c|c|c|c|c|c|c|c|c|c|c|}
\hline $\begin{array}{l}\tilde{\tilde{u}} \\
\frac{\pi}{\mathrm{c}}\end{array}$ & 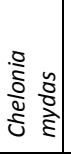 & 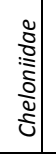 & 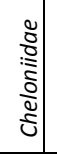 & 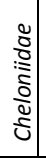 & 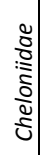 & 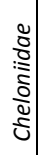 & $\begin{array}{l}\frac{8}{0} \\
: 0 \\
\frac{0}{8} \\
\text { ปे }\end{array}$ & 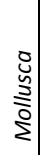 & & & & & $\begin{array}{l}0 \\
0 \\
0 \\
0 \\
3 \\
0 \\
0\end{array}$ & 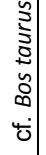 & 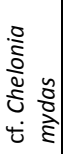 & 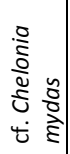 & 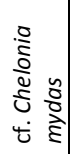 & 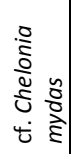 & 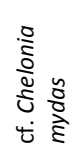 \\
\hline 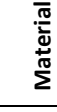 & $\begin{array}{c}\text { 矛 } \\
\overline{\tilde{w}}\end{array}$ & 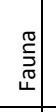 & 离 & 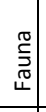 & 竝 & 勇 & 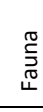 & 竝 & 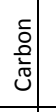 & 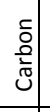 & $\begin{array}{l}0 \\
\frac{0}{\pi} \\
\frac{0}{0} \\
\mid\end{array}$ & 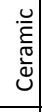 & 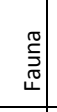 & 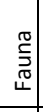 & 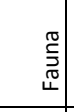 & 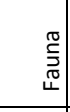 & 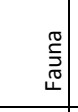 & 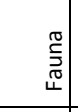 & $\begin{array}{l}\text { 胥 } \\
\text { 胥 }\end{array}$ \\
\hline 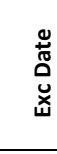 & 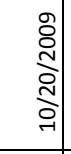 & 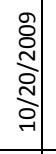 & 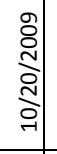 & 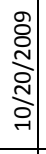 & 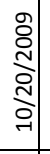 & 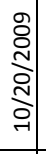 & 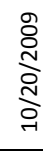 & 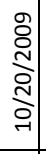 & 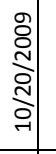 & 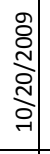 & 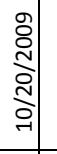 & 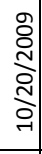 & 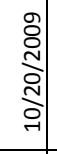 & 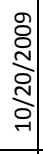 & 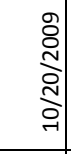 & 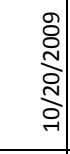 & 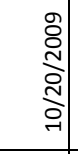 & 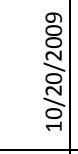 & 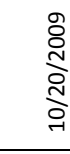 \\
\hline $\begin{array}{l}\text { ta } \\
\stackrel{0}{\Delta}\end{array}$ & 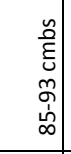 & 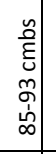 & 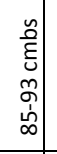 & 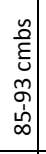 & 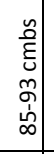 & 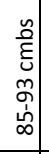 & 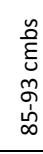 & 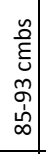 & 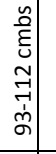 & 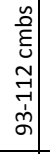 & 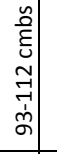 & 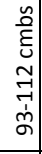 & 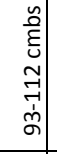 & 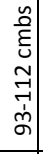 & 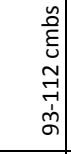 & 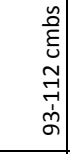 & 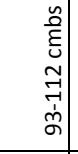 & 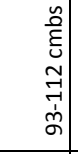 & $\begin{array}{l}\text { مै } \\
\text { है } \\
\text { जै } \\
\text { ñ }\end{array}$ \\
\hline $\begin{array}{c}\bar{\Xi} \\
\bar{\Xi}\end{array}$ & $m$ & $m$ & $m$ & $m$ & $m$ & $m$ & $m$ & $m$ & $\nabla$ & $\nabla$ & $\nabla$ & $\nabla$ & $\nabla$ & $\nabla$ & $\nabla$ & $\nabla$ & $\nabla$ & $\sigma$ & 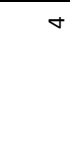 \\
\hline 5 & 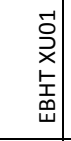 & 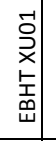 & $\begin{array}{l}\overrightarrow{0} \\
\vec{t} \\
\mathbf{t} \\
\text { 恶 }\end{array}$ & 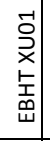 & 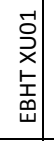 & 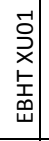 & 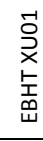 & $\begin{array}{l}\overrightarrow{0} \\
\overrightarrow{\hat{t}} \\
\underline{\mathbf{t}} \\
\underline{w} \\
\end{array}$ & 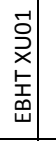 & 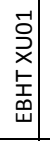 & 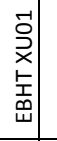 & 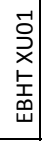 & 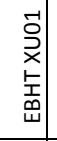 & $\begin{array}{l}\overrightarrow{0} \\
\overrightarrow{2} \\
\underline{t} \\
\underline{\underline{w}} \\
\underline{w}\end{array}$ & $\begin{array}{l}\vec{D} \\
\vec{x} \\
\mathbf{x} \\
\mathbf{5} \\
\mathbf{w} \\
\end{array}$ & 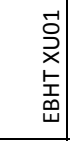 & 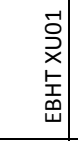 & 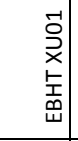 & 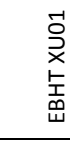 \\
\hline$\dot{\ddot{ٌ}}=$ & -1 & & & & & & & & & & & & & & $\sim$ & $m$ & $\infty$ & $\sigma$ & 요 \\
\hline 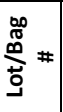 & 几 & in & n & $n$ & ก) & n & in & n & 0 & 0 & 0 & 6 & 0 & 0 & 6 & 6 & 6 & 0 & 0 \\
\hline
\end{tabular}




\begin{tabular}{|c|c|c|c|c|c|c|c|c|c|c|c|c|c|c|c|c|}
\hline 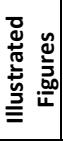 & & & & & & & & & & & & & & & & \\
\hline 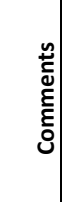 & 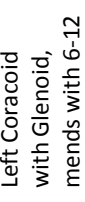 & 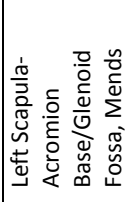 & 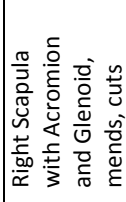 & 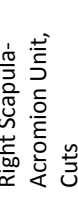 & 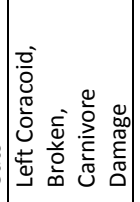 & 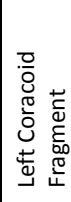 & 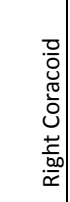 & 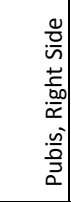 & 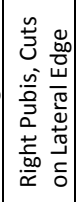 & 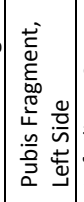 & 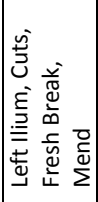 & 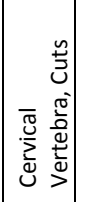 & 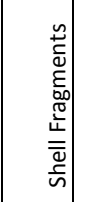 & 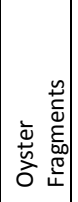 & 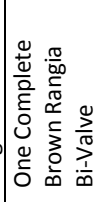 & 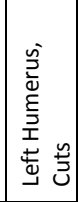 \\
\hline 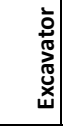 & 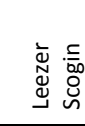 & 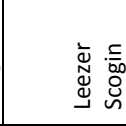 & 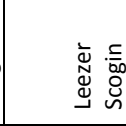 & 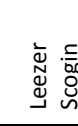 & 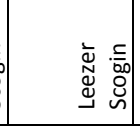 & 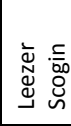 & 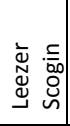 & 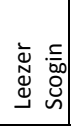 & 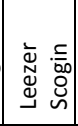 & 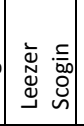 & 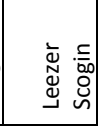 & 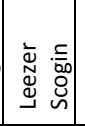 & 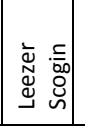 & 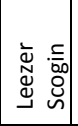 & 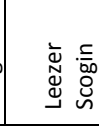 & 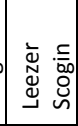 \\
\hline 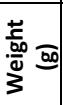 & $\stackrel{m}{*}$ & 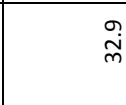 & $\underset{\infty}{\stackrel{D}{ }}$ & $\underset{\infty}{\tilde{D}}$ & $\begin{array}{l}\stackrel{\sigma}{\Gamma} \\
\end{array}$ & $\vec{j}$ & 尺 & $\begin{array}{c}2 \\
\stackrel{0}{0}\end{array}$ & $\begin{array}{c}\sigma \\
\dot{\infty} \\
\stackrel{2}{2}\end{array}$ & ㅇ & 8 & ه. & 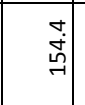 & $\stackrel{m}{\leftrightarrow}$ & $n$ & $\underset{\sim}{\stackrel{\sim}{\sim}}$ \\
\hline $\begin{array}{l}\mathbf{t} \\
0\end{array}$ & 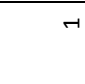 & $\rightarrow$ & $\sim$ & -7 & $\rightarrow$ & -1 & $\rightarrow$ & $\neg$ & $\rightarrow$ & 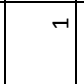 & $\sim$ & -1 & $\approx$ & $\nabla$ & $\rightarrow$ & - \\
\hline $\begin{array}{l}\frac{\tilde{\sigma}}{\tilde{J}} \\
\frac{1}{2}\end{array}$ & 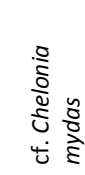 & 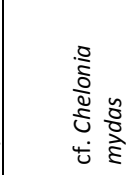 & 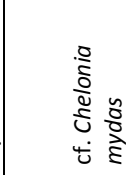 & 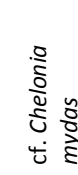 & 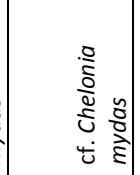 & 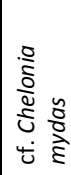 & 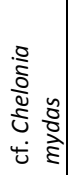 & 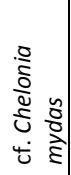 & 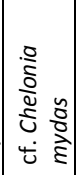 & 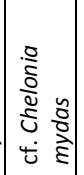 & 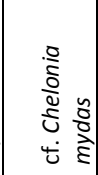 & 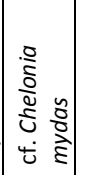 & 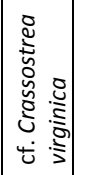 & 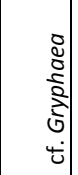 & 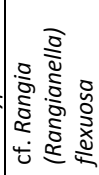 & : \\
\hline $\begin{array}{l}\overline{\bar{\sigma}} \\
\overline{\mathbb{v}} \\
\overline{\mathbb{\pi}} \\
\sum\end{array}$ & $\begin{array}{l}\stackrel{\pi}{5} \\
\underset{\tilde{c}}{\tilde{w}}\end{array}$ & 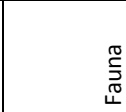 & 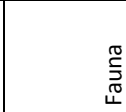 & 疍 & 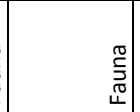 & $\begin{array}{l}\stackrel{0}{5} \\
\underset{\tilde{s}}{\tilde{\sigma}}\end{array}$ & 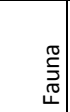 & 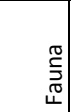 & 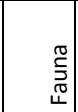 & 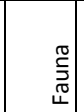 & 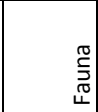 & 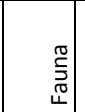 & 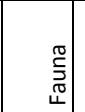 & 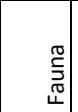 & 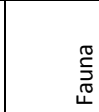 & 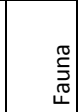 \\
\hline 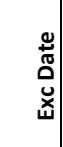 & $\begin{array}{l}\stackrel{8}{0} \\
\text { D̀ } \\
\text { ¿ }\end{array}$ & $\begin{array}{l}\text { oे } \\
\text { ¿े } \\
\text { o. }\end{array}$ & $\begin{array}{l}\text { oे } \\
\text { ¿े } \\
\text { ㅇ }\end{array}$ & $\begin{array}{l}\text { ò } \\
\text { İ } \\
\text { İ } \\
\text { I }\end{array}$ & 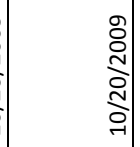 & 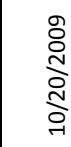 & $\begin{array}{l}0 \\
0 \\
0 \\
0 \\
0 \\
0\end{array}$ & 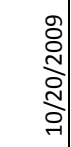 & 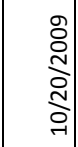 & 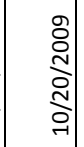 & 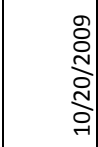 & $\begin{array}{l}0 \\
0 \\
\vdots \\
\vdots \\
\vdots \\
0\end{array}$ & $\begin{array}{l}0 \\
\vdots \\
\vdots \\
\vdots \\
\vdots \\
0\end{array}$ & 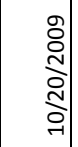 & 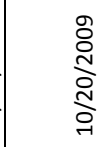 & $\begin{array}{l}\text { oे } \\
\text { ì } \\
\text { Dे } \\
\text { Oे }\end{array}$ \\
\hline 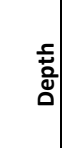 & 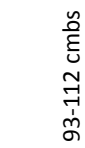 & 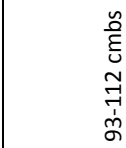 & \begin{tabular}{l}
$\stackrel{n}{0}$ \\
है \\
\multirow{I}{7}{} \\
ले
\end{tabular} & 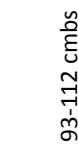 & 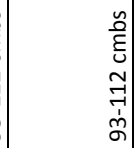 & 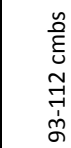 & 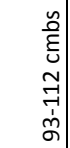 & 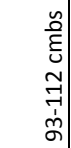 & 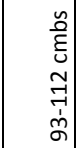 & 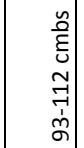 & 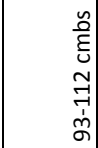 & 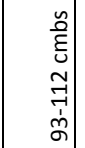 & 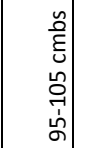 & 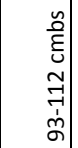 & $\begin{array}{l}\text { مै } \\
\text { है } \\
\text { مू } \\
\text { जे } \\
\text { ம் }\end{array}$ & 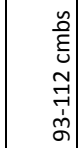 \\
\hline$\overline{\mathrm{J}}$ & $\sigma$ & $\sigma$ & $\nabla$ & $\nabla$ & $\nabla$ & $\nabla$ & $\nabla$ & $\nabla$ & $\nabla$ & $\nabla$ & 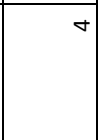 & $\nabla$ & $\nabla$ & $\nabla$ & $\nabla$ & $\sigma$ \\
\hline$\stackrel{5}{5}$ & 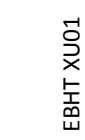 & 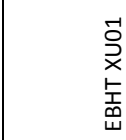 & 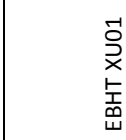 & 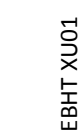 & 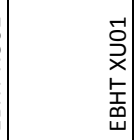 & 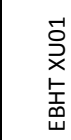 & 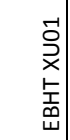 & 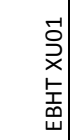 & 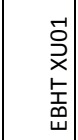 & 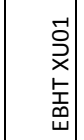 & 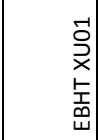 & 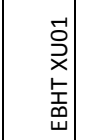 & 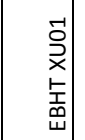 & 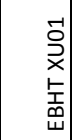 & 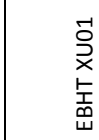 & 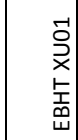 \\
\hline 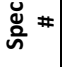 & $\exists$ & $\underset{\sim}{\Im}$ & $\stackrel{m}{\rightarrow}$ & H & $\stackrel{2}{\sim}$ & $\stackrel{\sim}{\sim}$ & ज & $\stackrel{\infty}{\sim}$ & $\rightarrow$ & i & $\vec{N}$ & $\approx$ & & & & -1 \\
\hline 总 & 0 & 0 & 0 & 0 & 0 & 0 & 0 & 6 & 0 & 0 & 0 & 0 & 0 & 6 & 6 & 6 \\
\hline
\end{tabular}




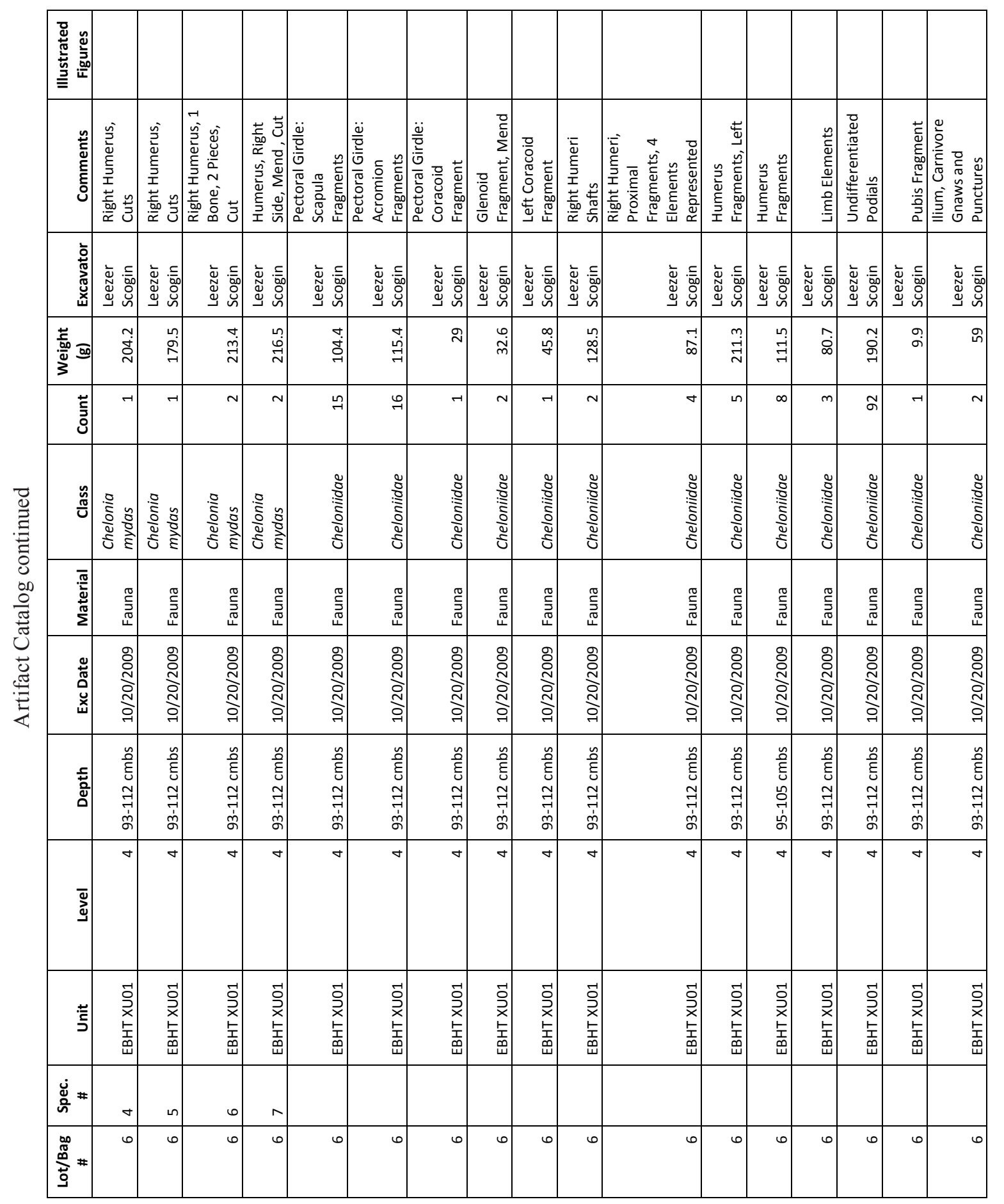




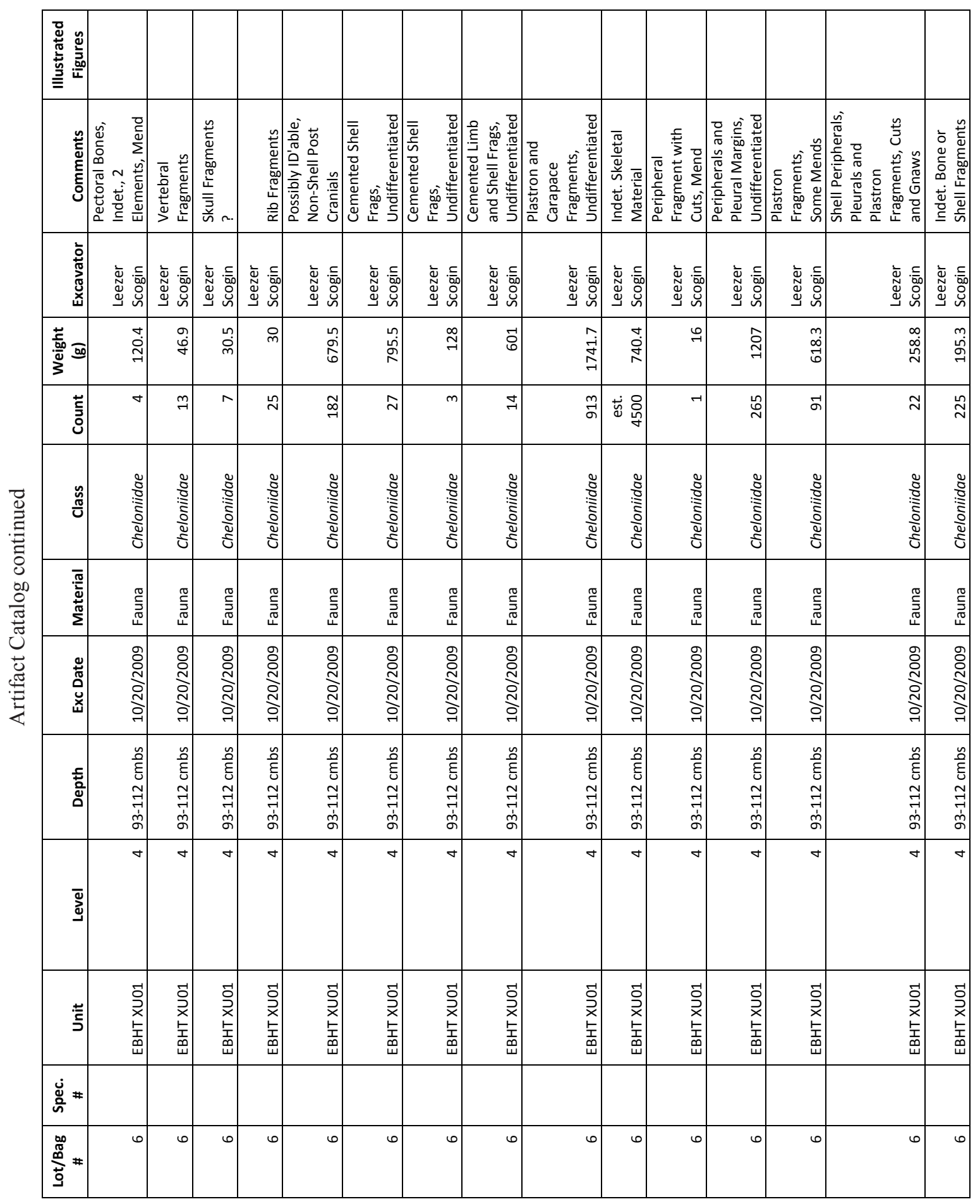




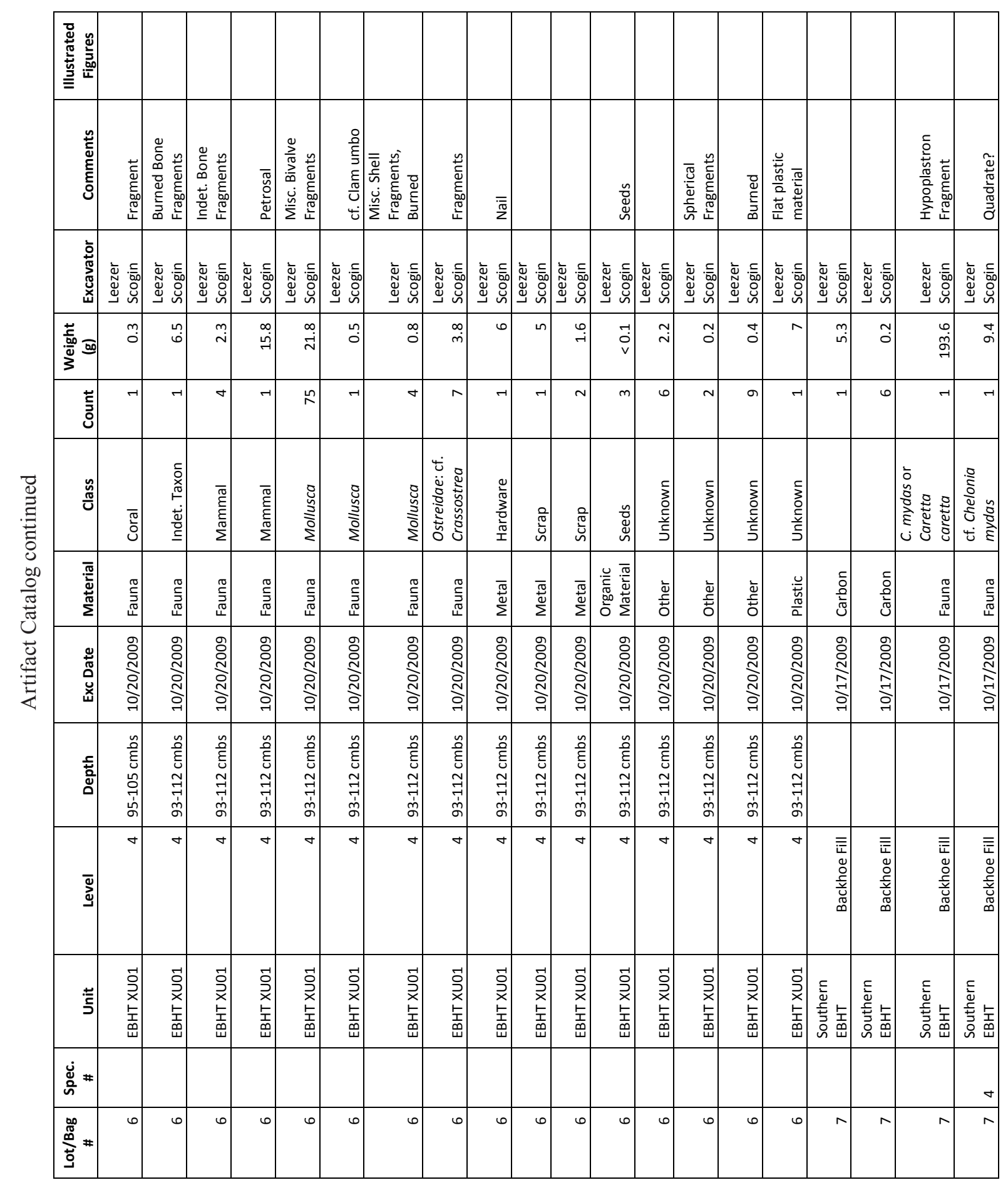




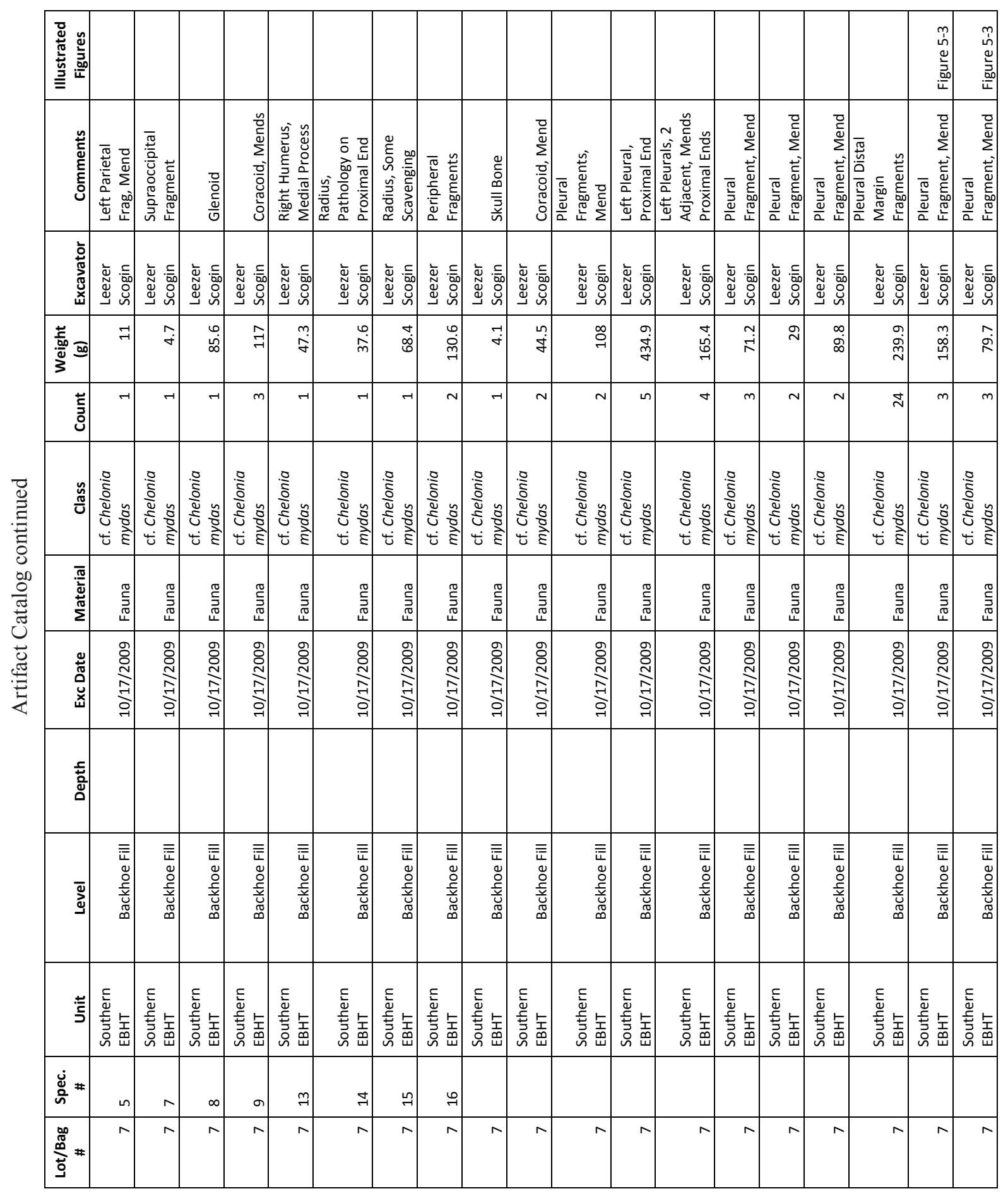




\begin{tabular}{|c|c|c|c|c|c|c|c|c|c|c|c|c|c|c|c|c|c|c|}
\hline 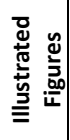 & 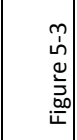 & & & & & & & & & & & & & & & & & \\
\hline 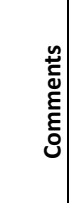 & 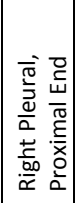 & 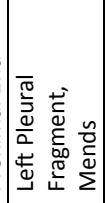 & 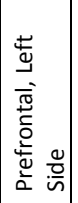 & 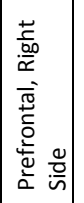 & 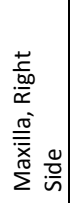 & 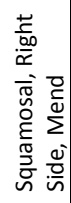 & 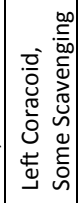 & 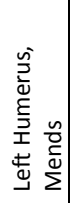 & 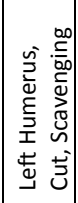 & 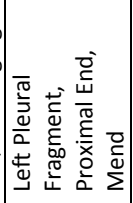 & 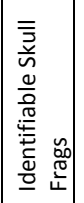 & 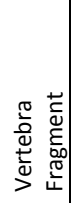 & 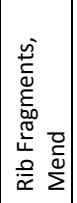 & 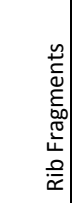 & 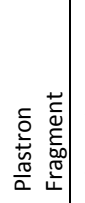 & 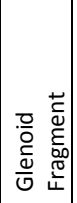 & 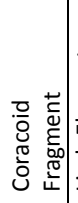 & 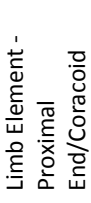 \\
\hline 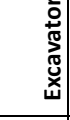 & 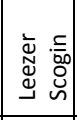 & 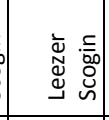 & 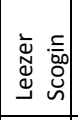 & 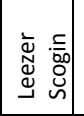 & 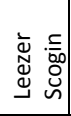 & 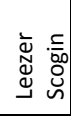 & 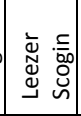 & 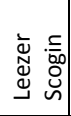 & 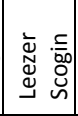 & 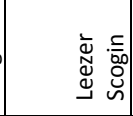 & 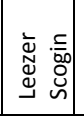 & 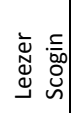 & 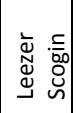 & 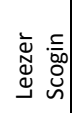 & 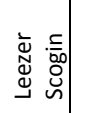 & 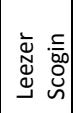 & 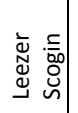 & 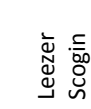 \\
\hline 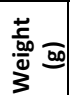 & $\stackrel{+}{i}$ & $\begin{array}{l}0 \\
\stackrel{0}{\sim} \\
\sim\end{array}$ & મُ & : & นٌ & $\underset{\underset{\sim}{\sim}}{\stackrel{N}{2}}$ & 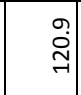 & 壳 & $\begin{array}{l}\text { : } \\
\stackrel{\sim}{n}\end{array}$ & $\stackrel{m}{\dot{f}}$ & $\hat{\sigma}$ & $\stackrel{\bullet}{i}$ & 이 & $\begin{array}{l}\vec{b} \\
\dot{p}\end{array}$ & $\begin{array}{r}9 \\
-1\end{array}$ & $\vec{i}$ & $\stackrel{\sim}{\sim}$ & $\stackrel{\sim}{\sim}$ \\
\hline $\begin{array}{l}\mathbf{t} \\
\mathrm{t} \\
\mathrm{u}\end{array}$ & $\sim$ & $\infty$ & -1 & -1 & 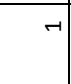 & $\sim$ & -1 & $m$ & -1 & $\sim$ & $m$ & 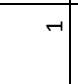 & $m$ & $\stackrel{2}{\sim}$ & -1 & $\rightarrow$ & $\rightarrow$ & -1 \\
\hline 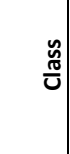 & 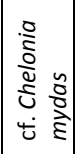 & 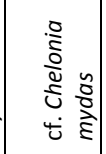 & 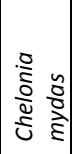 & 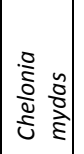 & 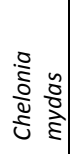 & 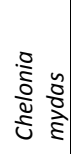 & 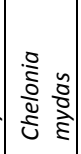 & 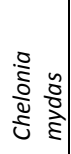 & 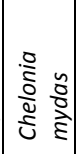 & 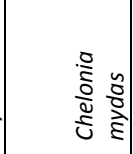 & $\begin{array}{c}\frac{8}{0} \\
\vdots \\
0 \\
0 \\
5\end{array}$ & $\begin{array}{c}\frac{8}{0} \\
: \\
\frac{0}{2} \\
5 \\
5\end{array}$ & 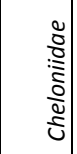 & 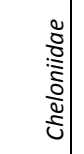 & $\begin{array}{l}\frac{0}{0} \\
: 0 \\
\frac{0}{2} \\
5 \\
5\end{array}$ & 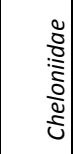 & $\begin{array}{l}\frac{8}{0} \\
\vdots \\
\frac{0}{2} \\
5 \\
5\end{array}$ & $\begin{array}{l}\text { : } \\
: \\
\frac{0}{2} \\
\text { ปे }\end{array}$ \\
\hline 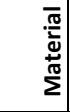 & 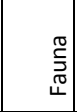 & 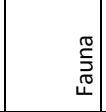 & 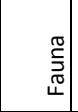 & 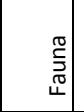 & 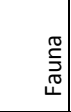 & 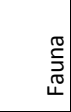 & 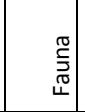 & 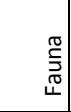 & 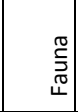 & 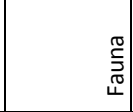 & 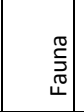 & 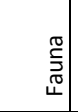 & 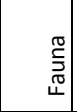 & 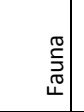 & 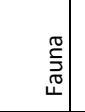 & 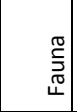 & 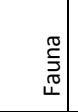 & 胥 \\
\hline 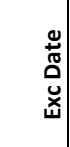 & 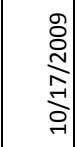 & 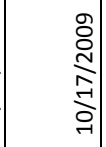 & 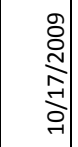 & 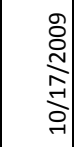 & 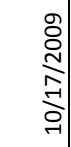 & 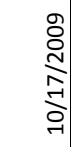 & 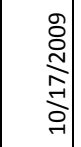 & 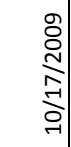 & 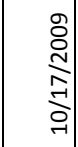 & 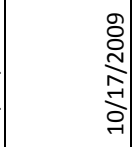 & $\begin{array}{l}\stackrel{8}{0} \\
\stackrel{5}{N} \\
\stackrel{-}{0}\end{array}$ & 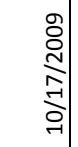 & 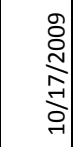 & 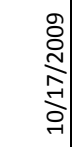 & 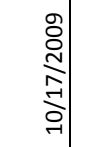 & 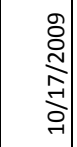 & 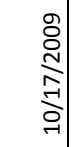 & 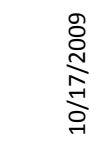 \\
\hline$\overline{\bar{\Xi}}$ & \begin{tabular}{l|l}
$\overline{\bar{i}}$ \\
0 \\
$o$ \\
$\bar{i}$ \\
$\infty$ \\
$\infty$
\end{tabular} & 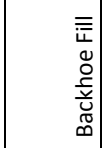 & 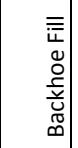 & 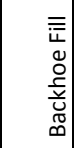 & $\begin{array}{l}\overline{\bar{i}} \\
0 \\
0 \\
\frac{5}{0} \\
\Phi \\
\infty\end{array}$ & $\begin{array}{l}\overline{\bar{i}} \\
0 \\
o \\
\bar{y} \\
\bar{\varpi} \\
\infty\end{array}$ & 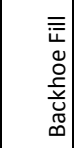 & $\begin{array}{l}\overline{\bar{i}} \\
0 \\
o \\
\frac{\bar{y}}{\mathbf{y}} \\
\Phi \\
\infty\end{array}$ & \begin{tabular}{l|l}
$\overline{\bar{i}}$ \\
0 \\
$o$ \\
$\bar{i}$ \\
$\infty$ \\
$\infty$
\end{tabular} & 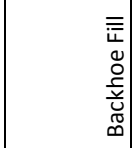 & 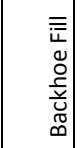 & 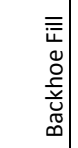 & 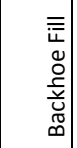 & \begin{tabular}{l|l}
$\overline{\bar{i}}$ \\
0 \\
$o$ \\
$\frac{0}{\bar{n}}$ \\
$\overline{0}$ \\
$\infty$
\end{tabular} & 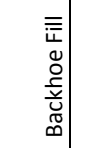 & $\begin{array}{l}\overline{\overline{\bar{u}}} \\
0 \\
0 \\
\overline{0} \\
\overline{0} \\
\infty\end{array}$ & 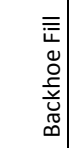 & 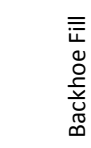 \\
\hline t: & 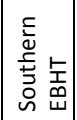 & 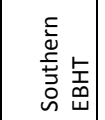 & 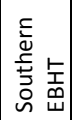 & 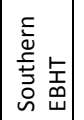 & 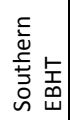 & 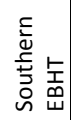 & 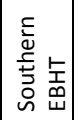 & 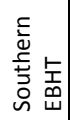 & 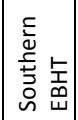 & 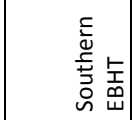 & 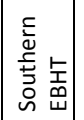 & 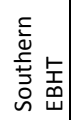 & 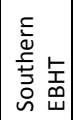 & 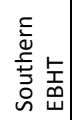 & 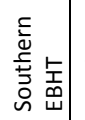 & 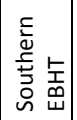 & 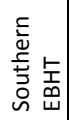 & 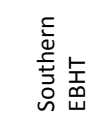 \\
\hline 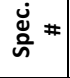 & & & $\neg$ & $\sim$ & $m$ & 0 & 이 & $\exists$ & $\approx$ & & & & & & & & & \\
\hline 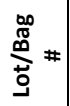 & & & $\wedge$ & $\wedge$ & $\wedge$ & ᄀ & $\wedge$ & $\wedge$ & $\wedge$ & $\wedge$ & $\wedge$ & 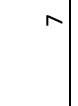 & 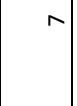 & 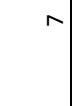 & 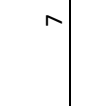 & $\wedge$ & $\wedge$ & r \\
\hline
\end{tabular}




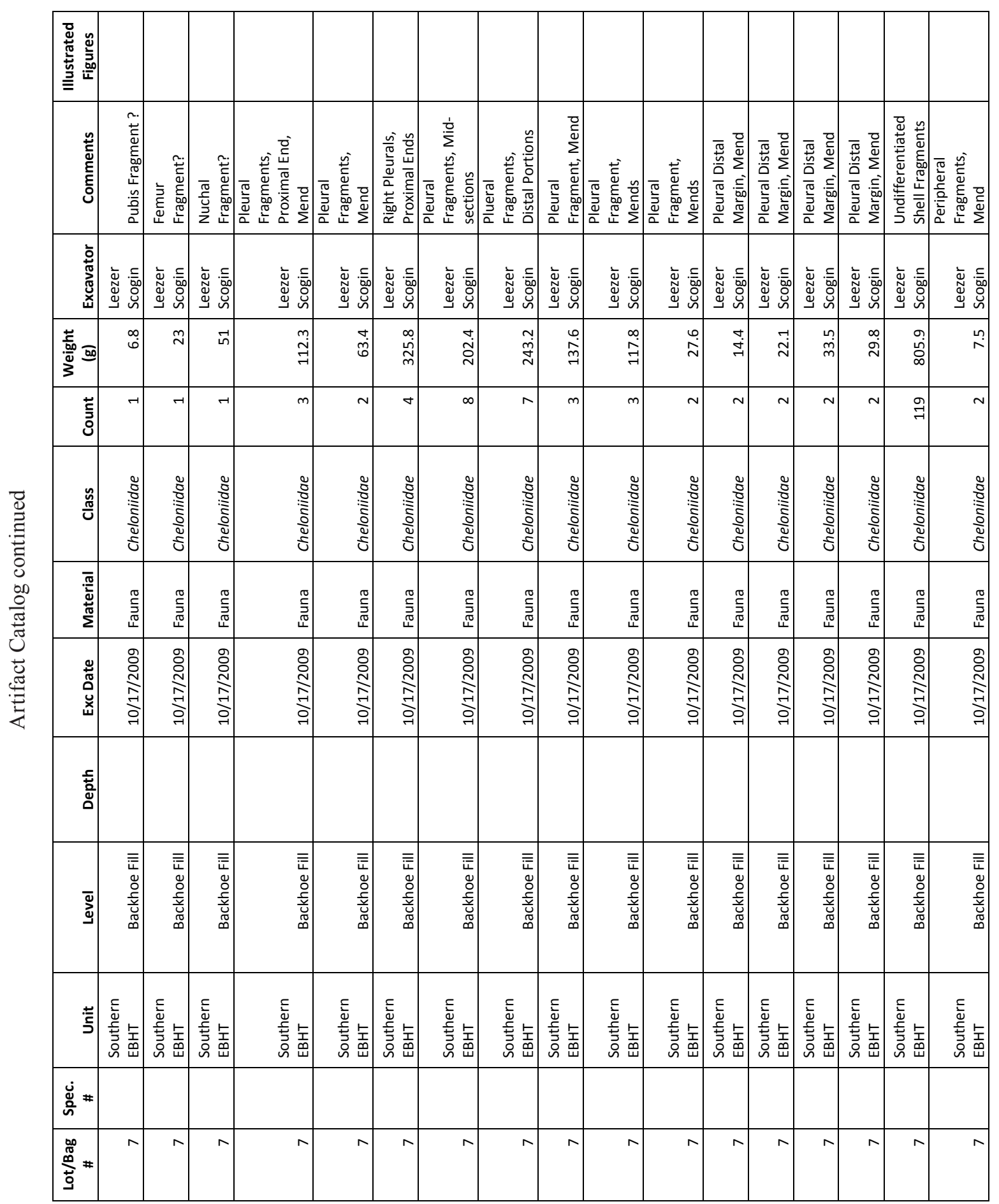




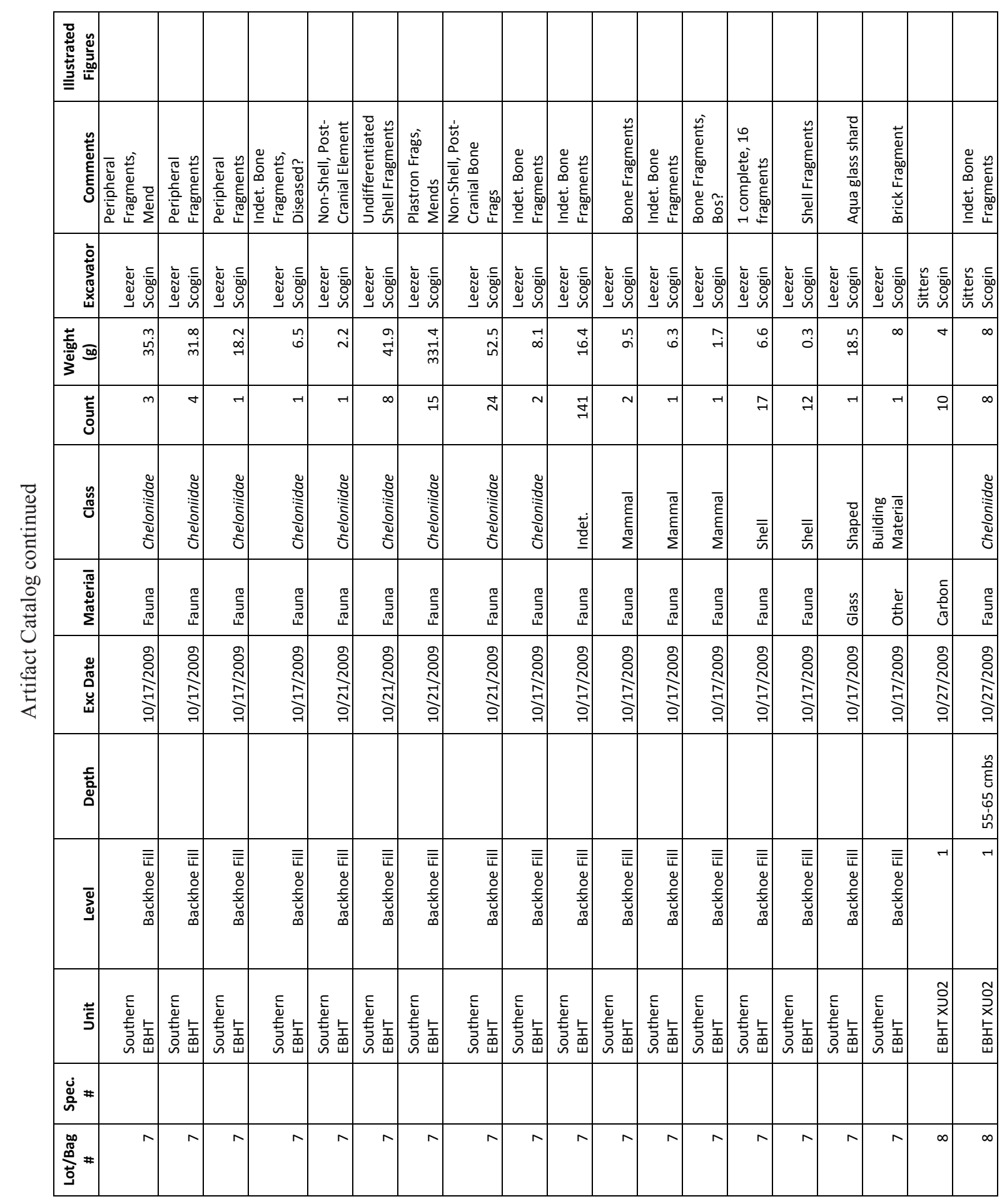




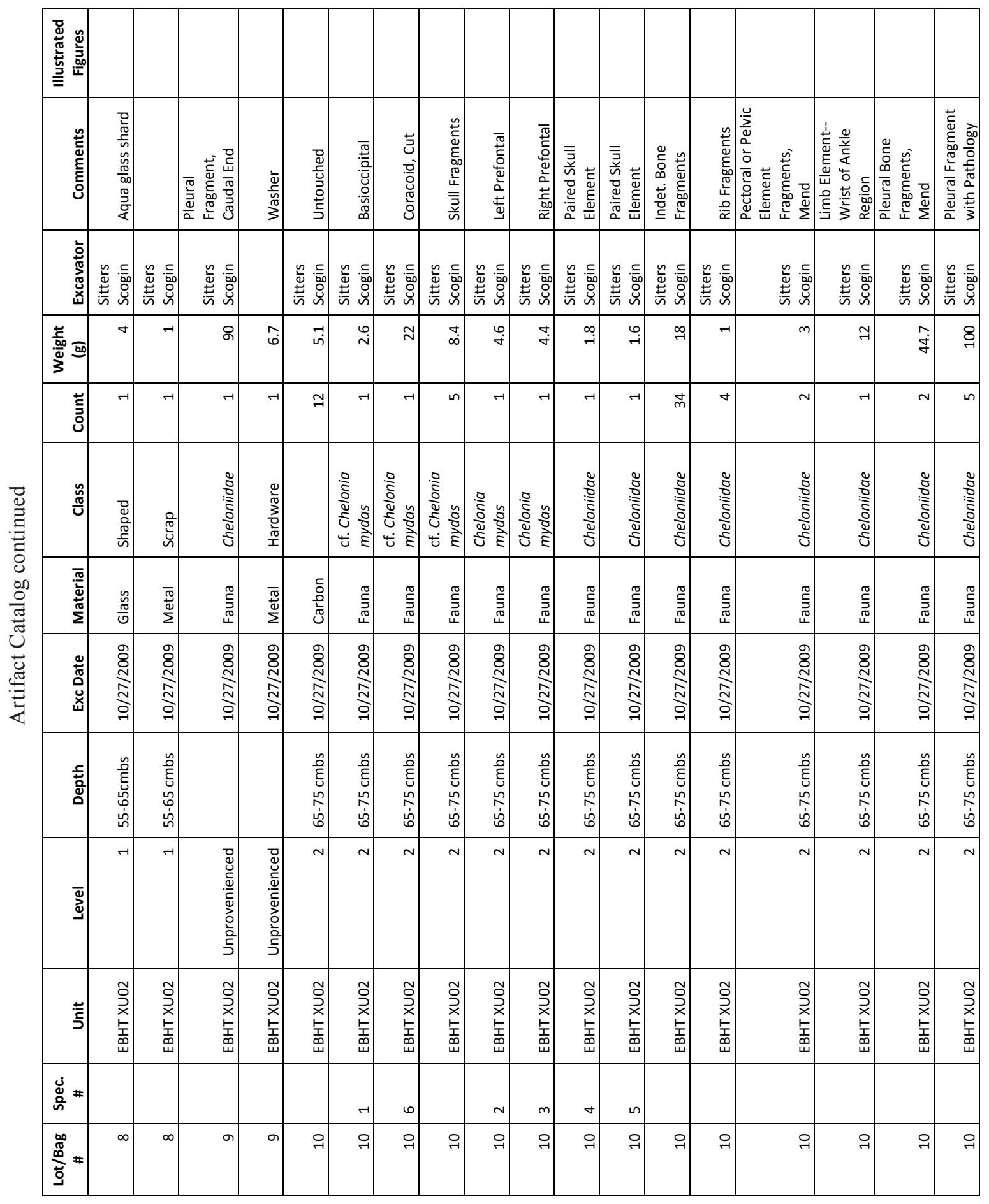




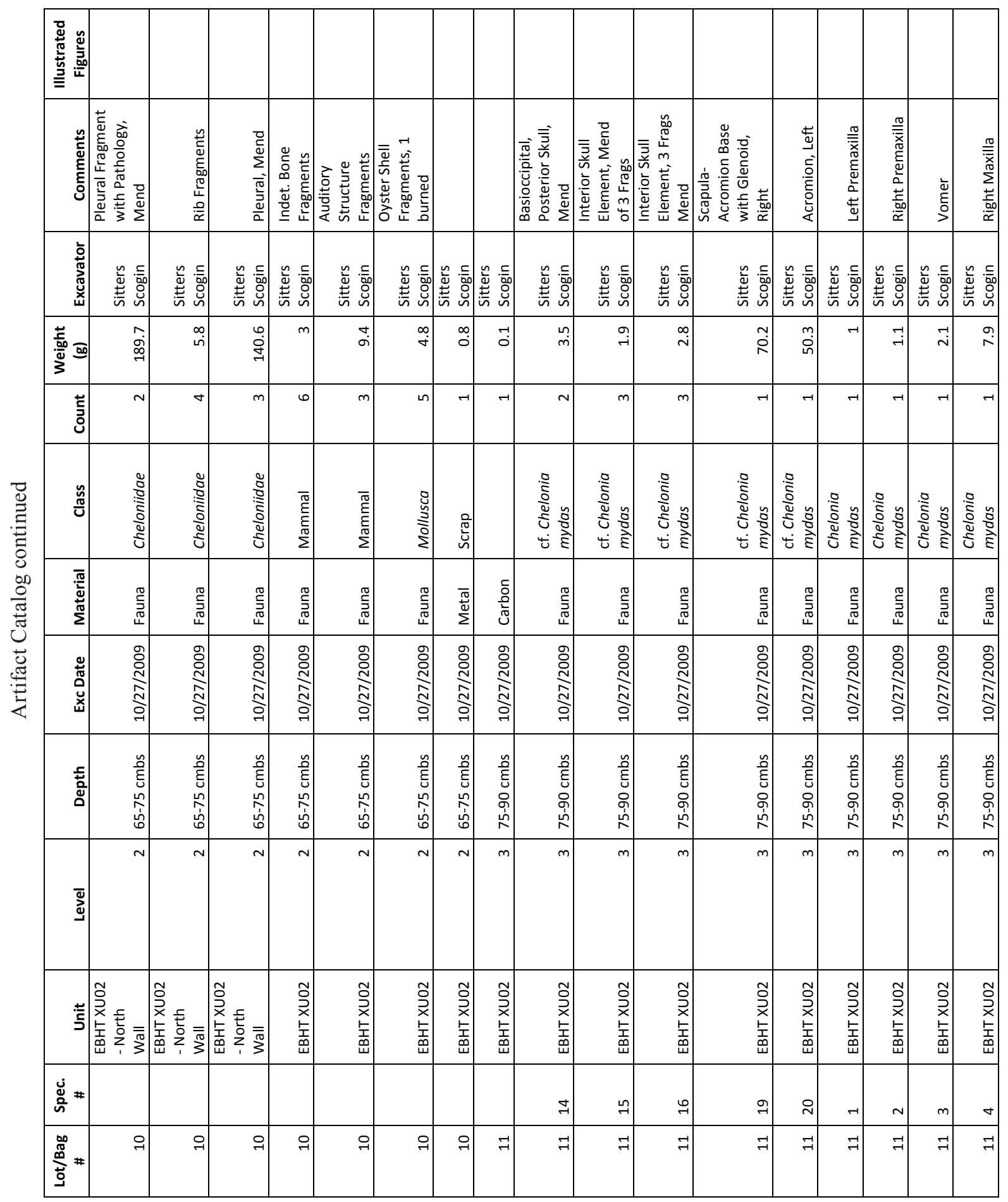




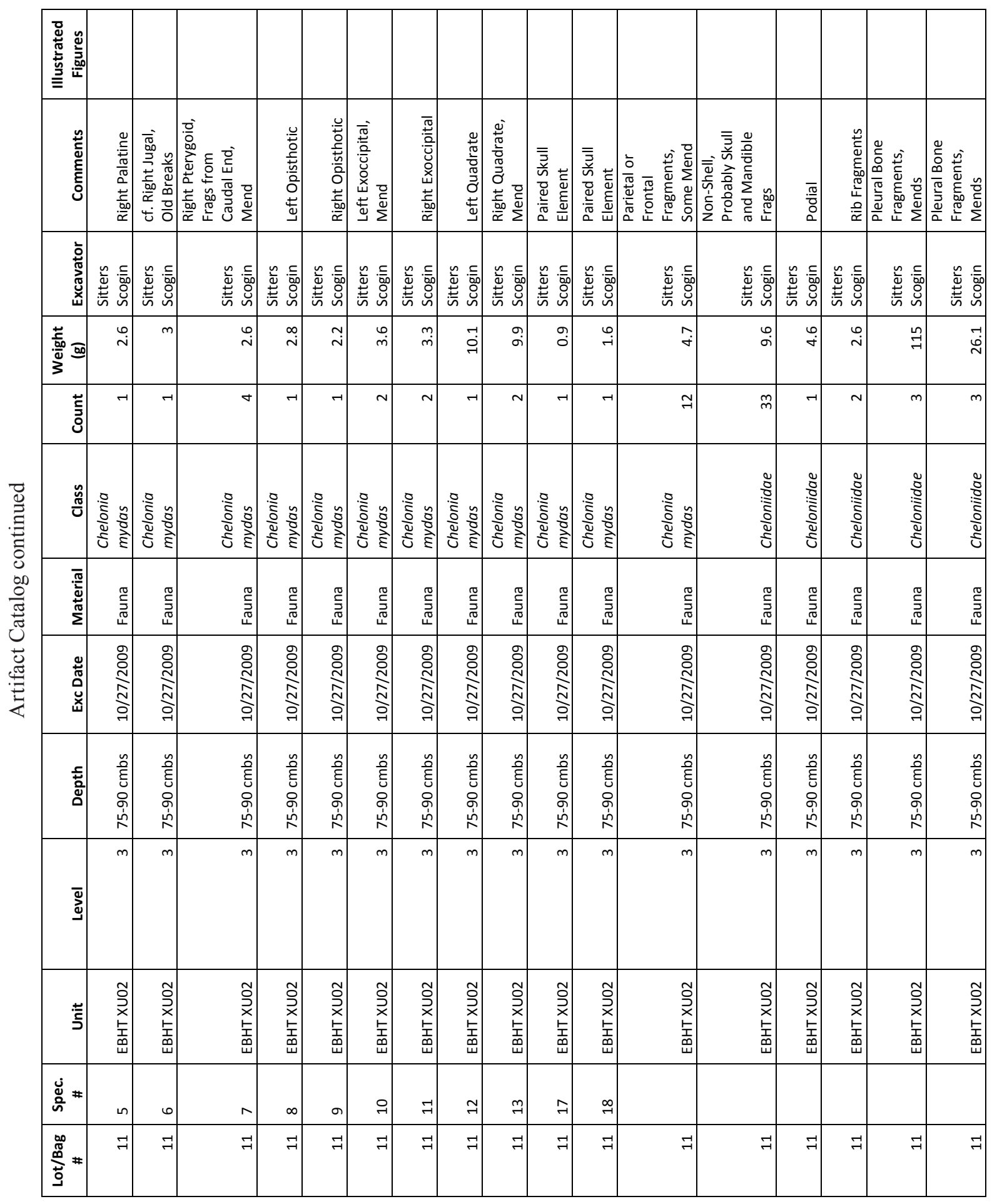




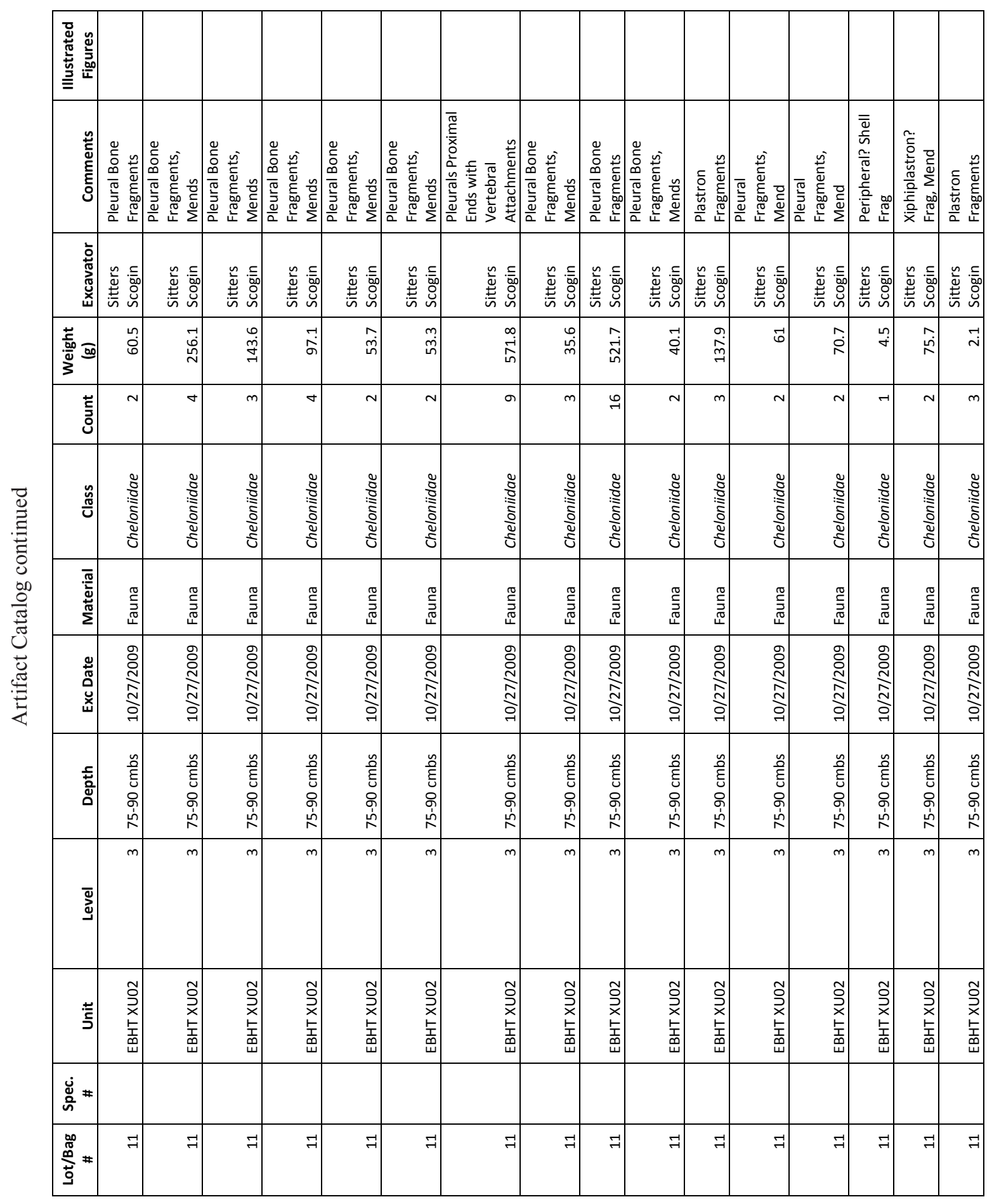




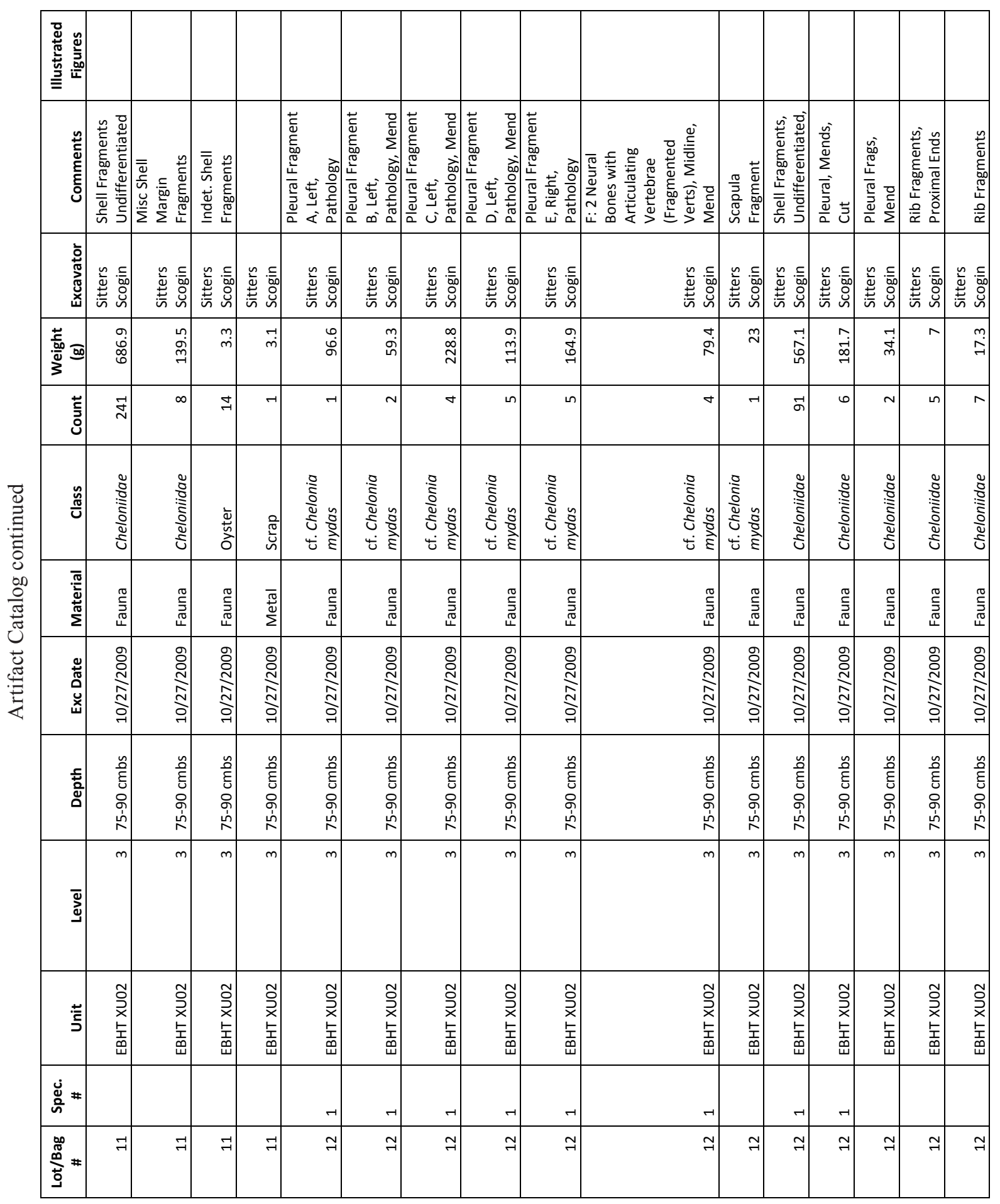




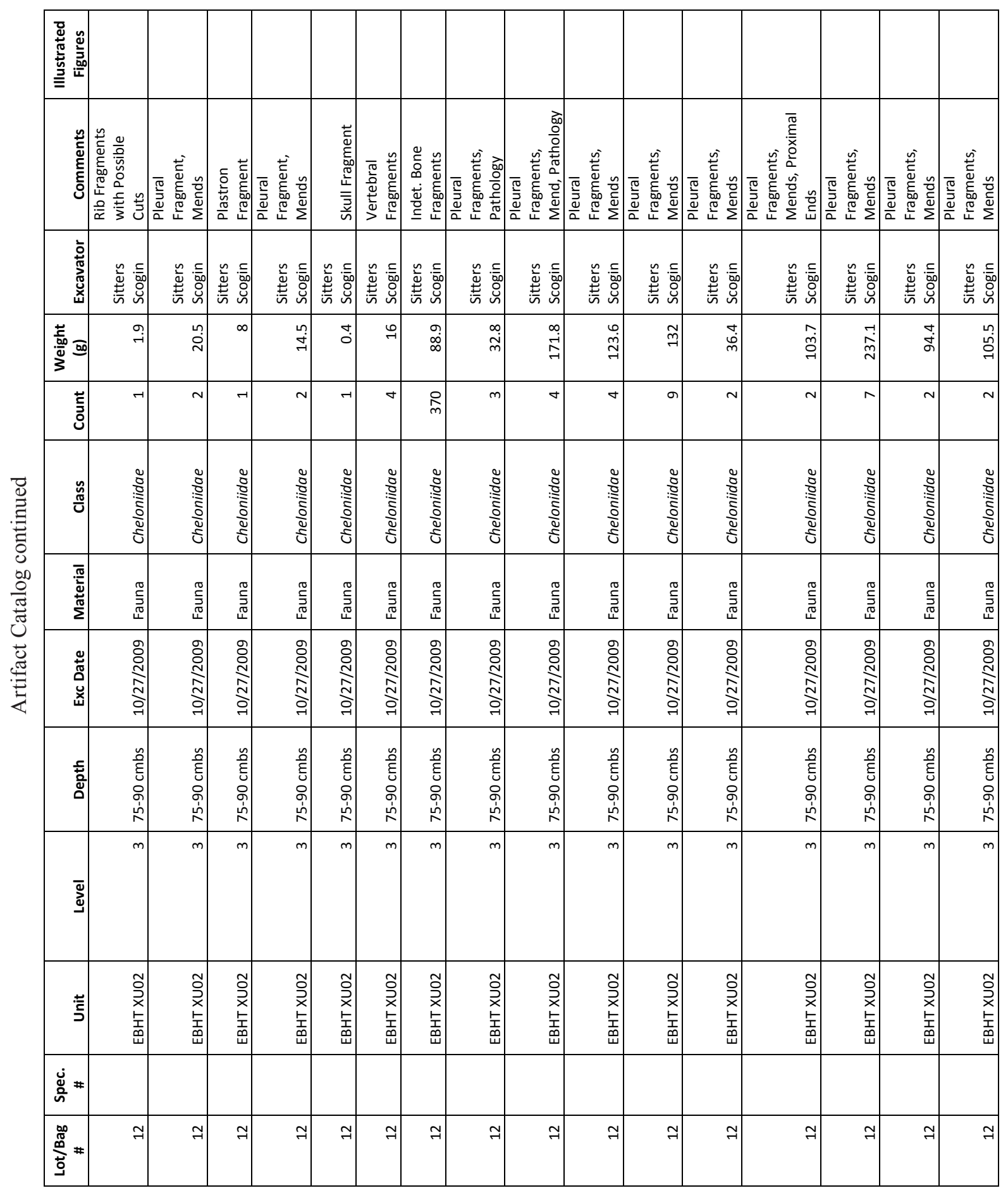




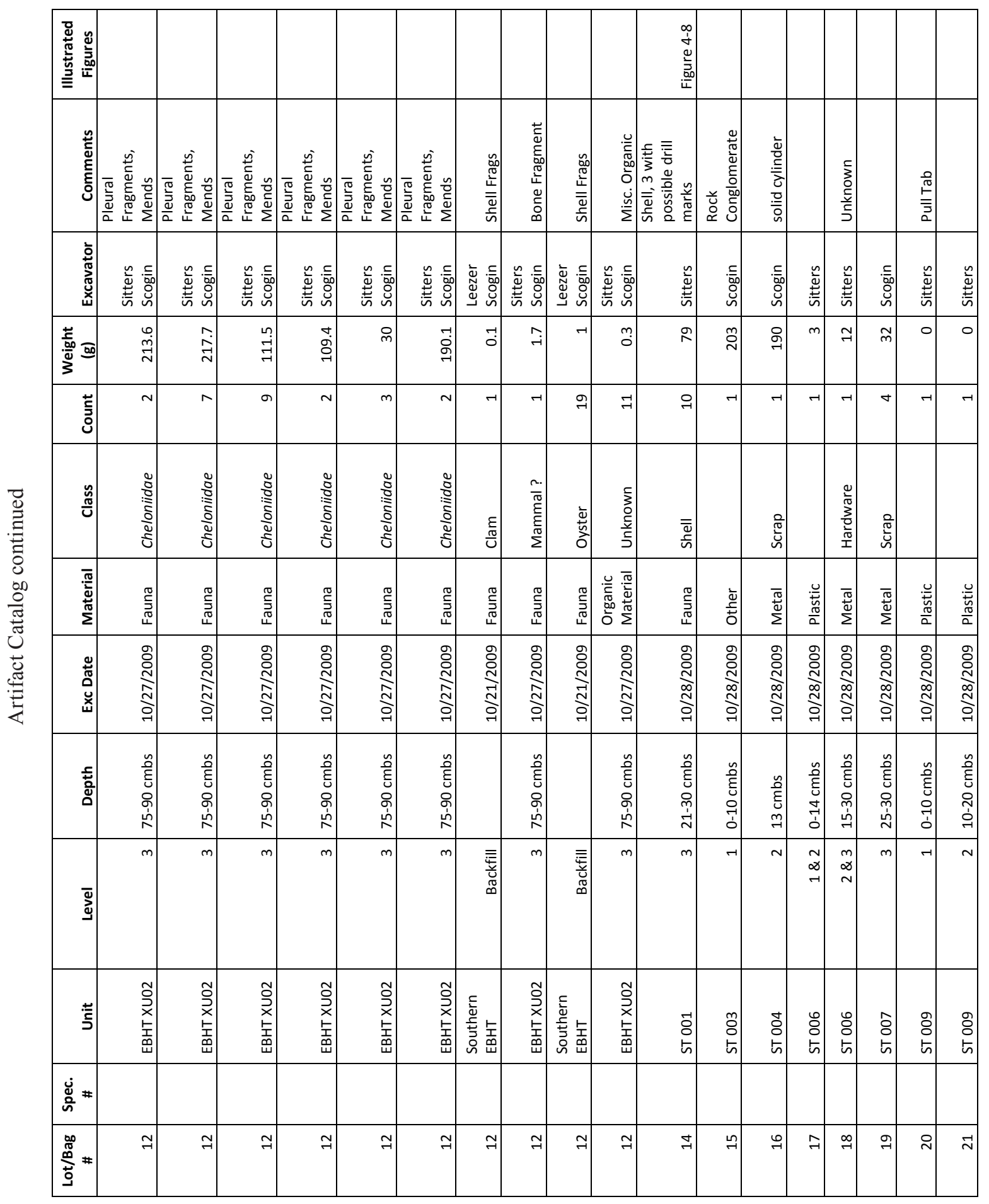




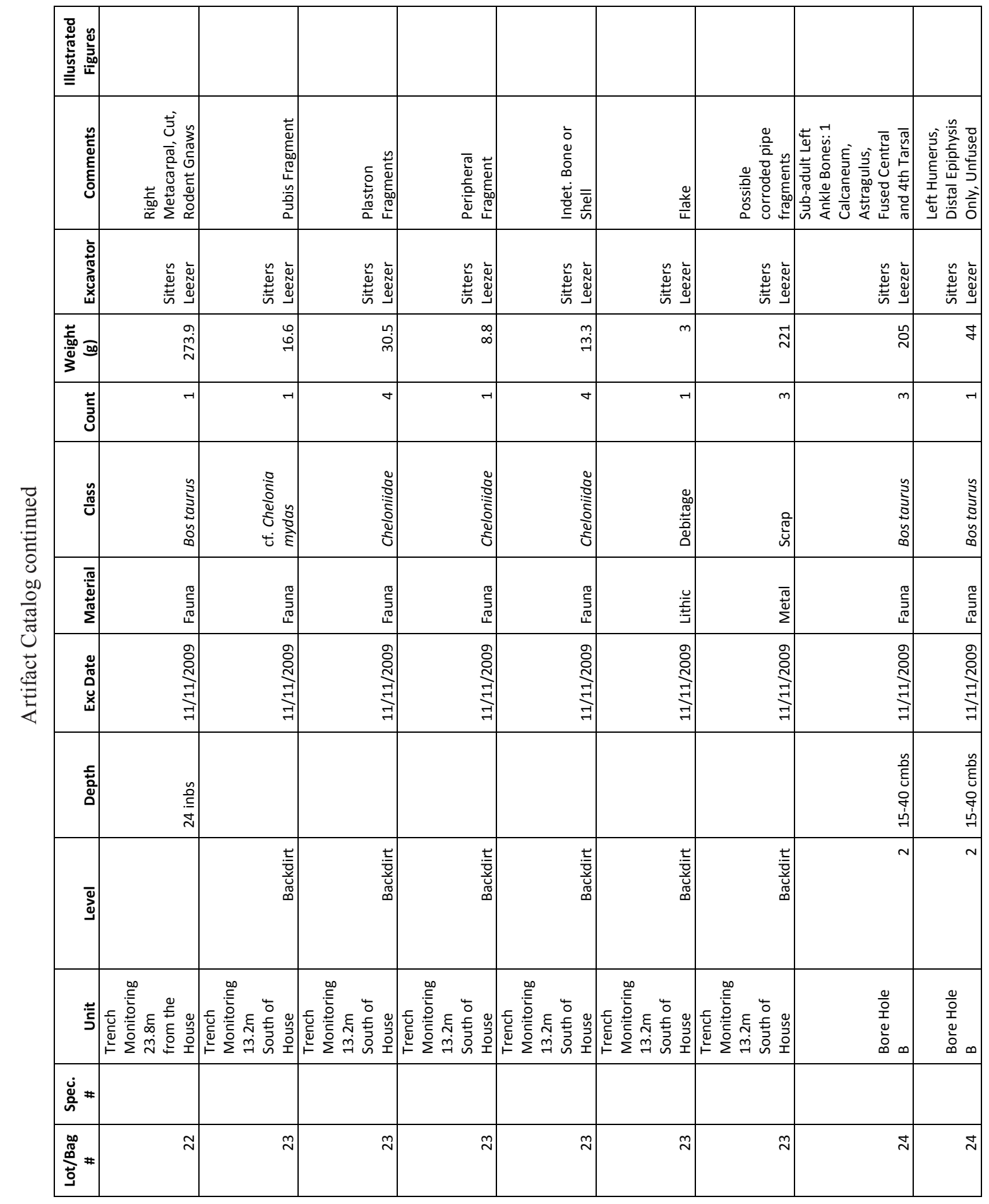




\begin{tabular}{|c|c|c|c|c|c|c|c|c|c|c|c|c|c|c|c|c|}
\hline 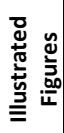 & & & & & & & & & & & & & & & & 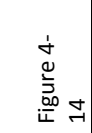 \\
\hline 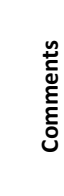 & 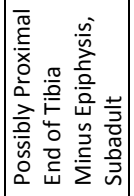 & 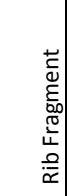 & $\frac{\sigma 0}{5}$ & 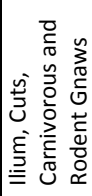 & 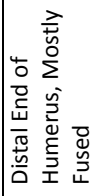 & 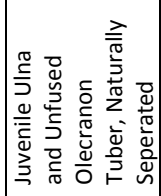 & 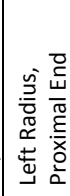 & 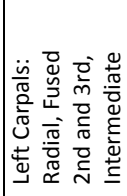 & 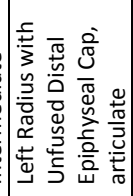 & 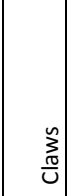 & 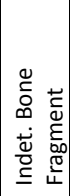 & 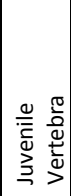 & 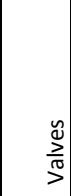 & 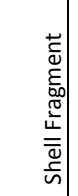 & 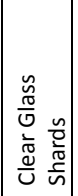 & 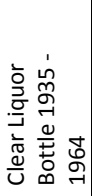 \\
\hline 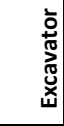 & 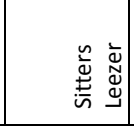 & 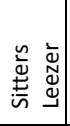 & 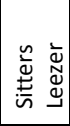 & 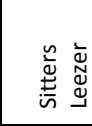 & 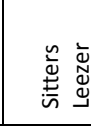 & 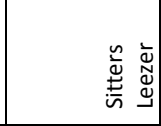 & 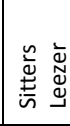 & 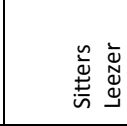 & 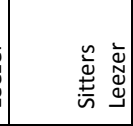 & 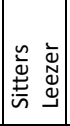 & 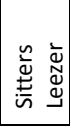 & 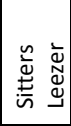 & 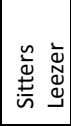 & 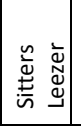 & 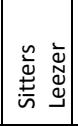 & 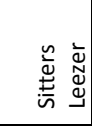 \\
\hline 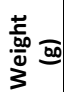 & $\stackrel{\sim}{\sim}$ & $\stackrel{\infty}{\dot{m}^{\prime}}$ & $\hat{\hat{\sigma}}$ & $\stackrel{ }{\circ}$ & $\hat{\imath}$ & $N$ & ळ & $\stackrel{\infty}{m}$ & 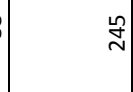 & $\vec{v}$ & $\stackrel{\circ}{\circ}$ & $r$ & $\stackrel{\hat{\sigma}}{-}$ & $m$ & $\exists$ & $\stackrel{\text { ¿ }}{\circ}$ \\
\hline 言 & $\rightarrow$ & 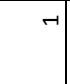 & $\sim$ & - & $-r$ & $\sim$ & - & $m$ & $\sim$ & $\sim$ & 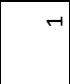 & -1 & $m$ & 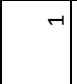 & $\exists$ & r \\
\hline $\begin{array}{l}\tilde{\mathscr{U}} \\
\frac{\pi}{\tilde{U}}\end{array}$ & 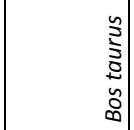 & 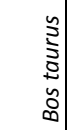 & \begin{tabular}{l}
$\frac{n}{3}$ \\
\multirow{5}{5}{} \\
$\stackrel{5}{0}$ \\
$\infty$
\end{tabular} & $\begin{array}{l}\frac{n}{3} \\
\bar{s} \\
\tilde{y} \\
\infty\end{array}$ & 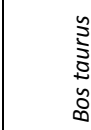 & 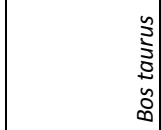 & $\begin{array}{l}\text { s. } \\
\text { s. } \\
\text { s. } \\
\infty \\
\infty\end{array}$ & 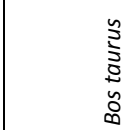 & 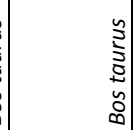 & 窇 & $\begin{array}{l}\overline{\widetilde{\sigma}} \\
\stackrel{\xi}{\xi} \\
\stackrel{\tilde{\sigma}}{\Sigma}\end{array}$ & 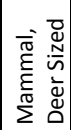 & 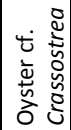 & 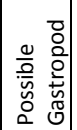 & 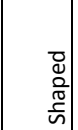 & $\begin{array}{l}\frac{\delta}{0} \\
\frac{0}{\sigma} \\
\frac{\sigma}{\omega}\end{array}$ \\
\hline 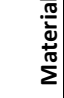 & 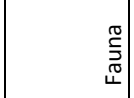 & 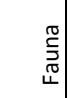 & $\begin{array}{l}\frac{\pi}{5} \\
\stackrel{5}{\sigma}\end{array}$ & 胥 & 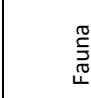 & 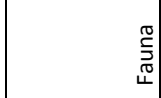 & 芧 & 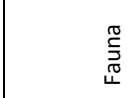 & 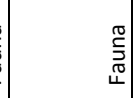 & 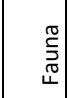 & 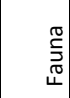 & 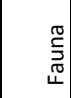 & 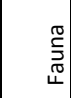 & 离 & 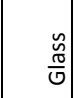 & $\begin{array}{l}\frac{\widetilde{U}}{\omega} \\
\frac{\pi}{\pi}\end{array}$ \\
\hline 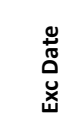 & 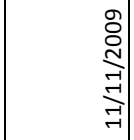 & 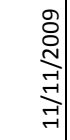 & 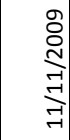 & 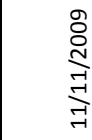 & 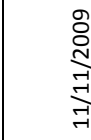 & 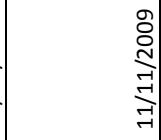 & 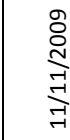 & 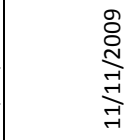 & 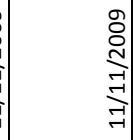 & 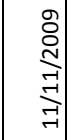 & 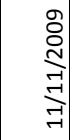 & 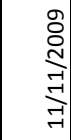 & 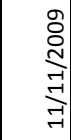 & 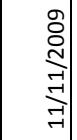 & 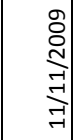 & 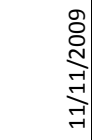 \\
\hline $\begin{array}{l}\overline{\mathbf{z}} \\
\mathrm{a}\end{array}$ & 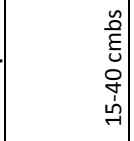 & 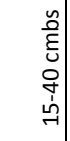 & 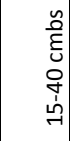 & 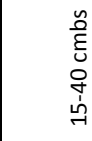 & $\begin{array}{l}\text { مै } \\
\text { है } \\
\text { ơ } \\
\text { 을 }\end{array}$ & 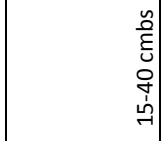 & $\begin{array}{l}\text { مै } \\
\text { है } \\
\text { ơ } \\
\text { ปे } \\
\text { คे }\end{array}$ & 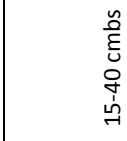 & 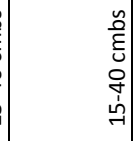 & 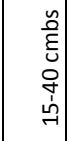 & 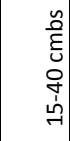 & 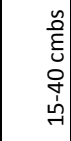 & 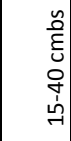 & 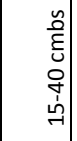 & 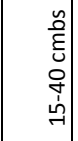 & 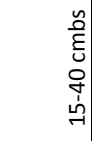 \\
\hline$\overline{\stackrel{\Xi}{\Xi}}$ & $\sim$ & $N$ & $\sim$ & $\sim$ & $\sim$ & $\sim$ & $\sim$ & $\sim$ & $\sim$ & $N$ & $\sim$ & $\sim$ & $\sim$ & $N$ & $N$ & $\sim$ \\
\hline 蒿 & 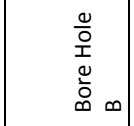 & $\begin{array}{l}\frac{0}{0} \\
\text { ⿳亠口冋 } \\
\stackrel{0}{0} \\
\infty\end{array}$ & 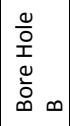 & 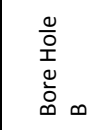 & 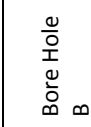 & 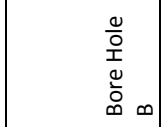 & 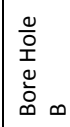 & 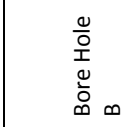 & 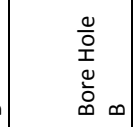 & 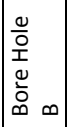 & 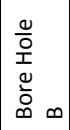 & 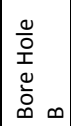 & 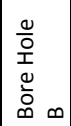 & 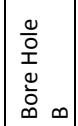 & 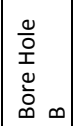 & 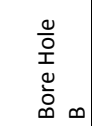 \\
\hline 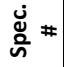 & & & & & & & & & & & & & & & & \\
\hline 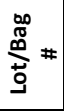 & \pm & $\stackrel{\sim}{\sim}$ & $\stackrel{\sim}{\sim}$ & $\mathbb{N}$ & $\stackrel{d}{\sim}$ & $\stackrel{\sim}{\sim}$ & $\stackrel{\sim}{\sim}$ & $\stackrel{\Xi}{\sim}$ & $\stackrel{\sim}{\sim}$ & 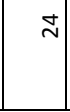 & $\stackrel{J}{\sim}$ & $\stackrel{\sim}{N}$ & $\stackrel{\sim}{\sim}$ & $\stackrel{\sim}{\sim}$ & $\stackrel{\sim}{\sim}$ & $\stackrel{\Xi}{\sim}$ \\
\hline
\end{tabular}




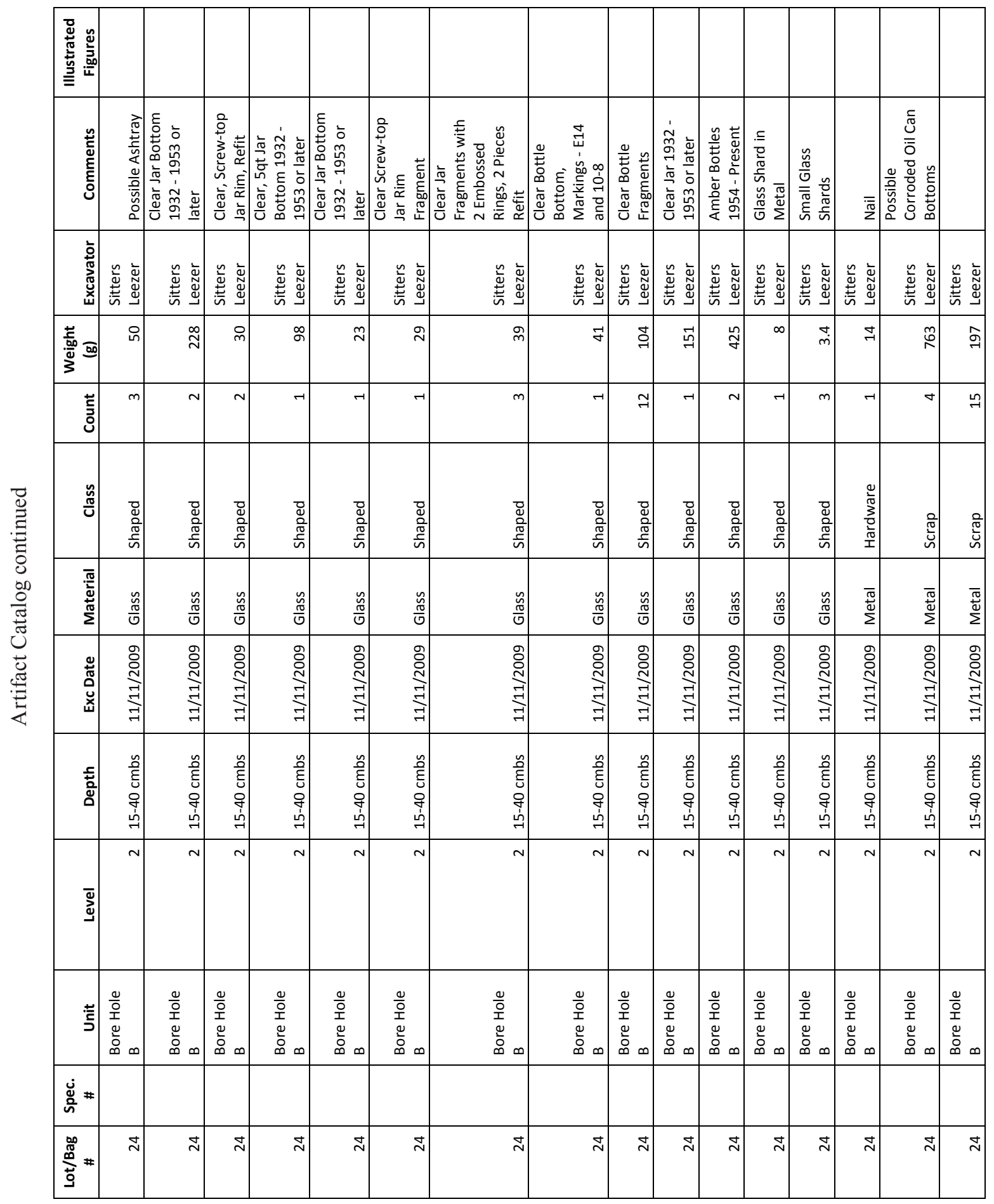




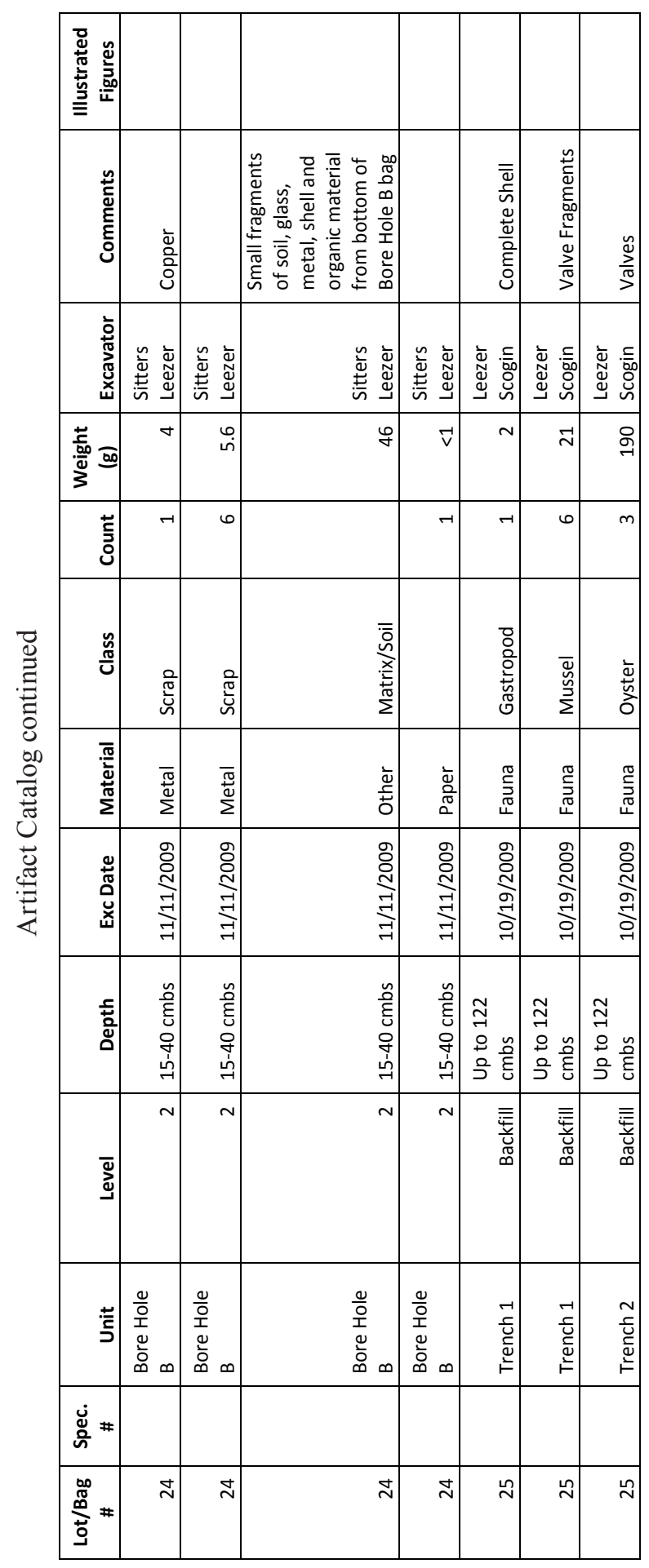

